\title{
VOLUNTARY BUSINESS INITIATIVES CAN REDUCE PUBLIC PRESSURE FOR REGULATING FIRM BEHAVIOUR ABROAD*
}

\author{
Dennis Kolcava $^{\dagger} \quad$ Lukas Rudolph ${ }^{\ddagger} \quad$ Thomas Bernauer $\S$
}

\section{Author's manuscript, submitted version. Article published in Journal of European Public Policy, online at: http://dx.doi.org/10.1080/13501763.2020.1751244.}

\begin{abstract}
Almost all regulatory policy stops at the national border. Thus, when conducting business abroad, the behaviour of firms is r egulated by their h ost, n ot t heir home country. Yet, international institutions have issued (non-binding) codes of conduct on social/environmental aspects of firm behaviour, and various high-income countries discuss how to improve extraterritorial firm b ehaviour - with high political contestation over the appropriate mix of state intervention and corporate self-regulation. Exploiting a unique national referendum on this issue in Switzerland, we investigate how these interact from a public opinion standpoint. Based on a nationally representative survey experiment $(\mathrm{N}=1564)$, we find that while baseline support for state intervention is high (approx. 60\%), corporate self-regulation decreases such support. However, only credible voluntary business initiatives lead to substantial reductions. Our results speak to a broad policy debate in European countries and the EU on how to ensure compliance of firms with human rights and environmental standards.
\end{abstract}

Keywords: corporate social responsibility, environmental and human rights standards, public opinion, regulatory policy, survey experiment, voting behaviour

*Authors' note: We are grateful to Dominik Hangartner, Edmund Malesky and Stefanie Walter for valuable feedback on the research design and to Angélica Serrano and Robert Huber for valuable feedback on the survey instrument. Michael Wicki, Federica Genovese, seminar audiences at ETH Zurich, and participants at the Swiss Political Science Association Annual Conference 2019 and the European Political Science Association Annual Conference 2019 provided helpful comments. We thank Dennis Atzenhofer and Alexia Sotelo Beyza for excellent research assistance. This research was supported by the Swiss National Science Foundation (SNSF) within the framework of the National Research Programme Sustainable Economy: resource-friendly, future-oriented, innovative (NRP 73 Grant: 407340 - 172363).

${ }^{\dagger}$ ETH Zurich, Haldeneggsteig 4, 8092 Zürich dennis.kolcava@ir.gess.ethz.ch (corresponding author)

${ }^{\ddagger}$ ETH Zurich, Haldeneggsteig 4, 8092 Zürich lukas.rudolph@gess.ethz.de

${ }^{\S}$ ETH Zurich, Haldeneggsteig 4, 8092 Zürich thbe0520@ethz.ch 


\section{Introduction}

Most economic activity is associated with some negative externalities (Buchanan \& Stubblebine 1962, Pigou 1920). With advancing economic globalisation, such externalities have increasingly diffused over wider geographic areas. Examples often include cases where environmental (e.g. water and air pollution), or social (e.g. child labour) impacts develop during production in low-income countries, although value-added or consumption eventually takes place in high-income countries. Academic research has made considerable progress in conceptualizing - e.g. as ecological footprints - and quantifying such externalities (Aklin 2016, Lutter et al. 2016, Peters et al. 2011, Wackernagel et al. 1999). Moreover, various social and environmental minimum standards for international business activities have emerged, often coordinated and issued by international institutions (OECD 2018, UNEP 2011). These standard-setting efforts have resulted in a near-global consensus that, irrespective of location, business enterprises must respect human rights and protect the environment and that states must apply such standards to all enterprises domiciled in their jurisdiction (United Nations 2011).

It remains contested, however, whether government intervention is needed to implement and enforce such norms and to what extent the issue can or should be left to self-regulation by economic actors (e.g. firms or business associations) Abbott \& Snidal 2001, Kinderman 2016, Locke 2013, Meyer 2013, O'Rourke 2003, Tosun et al. 2016, Vogel 2006).

With only few exceptions, such as anti-slavery (e.g. the UK's 'Modern Slavery Act', 2015), anti-corruption (e.g. the Swiss anti-corruption law, 2006), and international economic sanctions laws (e.g. US sanctions on Iran), countries do not usually regulate the behaviour of domestic firms that invest, produce, or source goods and services in/from other countries. Nevertheless, several high-income countries have recently considered (e.g., 
Germany, Netherlands) or enacted (e.g., France, United Kingdom) new regulation in this area (e.g. France's 'Duty of Vigilance Law', 2017). Political battles currently wage over the appropriate combination of state intervention and corporate self-regulation (see Federal Foreign Oce 2016, Hecking 2017, Koch 2018, Spiegel Online 2019, Weydt \& Küstner 2019).

Against this backdrop, we examine mass public (citizens') preferences on extraterritorial social and environmental regulation, corporate self-regulation, and, in particular, the interplay between them. Our focus lies on whether public demand for government intervention is affected by corporate behaviour and, notably, by voluntary business initiatives. This relationship is vital because it involves a potential incentive for firms to self-regulate and reduce externalities of their economic activity on their own accord as soon as some public regulatory pressure looms.

In our study, we build on a recent argument by Malhotra et al. (2018) and carry it forward from local and national environmental policymaking to the issue of regulating corporate behaviour abroad. Building on this argument, we hypothesise that citizens may use corporate action as a source of information to learn about the degree to which the private sector resolves an (e.g. environmental) problem. More specifically, we hypothesise that voluntary corporate responsibility measures have several dimensions that induce a potential crowding-out effect on public demand for government intervention. First, is the corporate sector addressing the substantive problem meaningfully and to what extent is the industry involved? This concerns the 'breadth' of the efforts, i.e. the share of private sector corporations taking action. Additionally, it also comprises the type of corporations that participate (whom regulation would target), i.e. whether industry laggards or specific firms at high risk of violating standards are involved. Second, does the particular design of corporate responsibility measures credibly indicate a change in expected behaviour, i.e. 
is there some type of monitoring of voluntary firm behaviour?

To test these arguments, we use survey experiments in which we vary what the corporate sector does and investigate whether citizens change their demand for government intervention. In this case, the empirical focus is on Switzerland, where we can test our arguments in a realistic setting - our survey participants, Swiss citizens, are regularly asked to decide by popular vote on regulatory policy. Specifically, a citizen-initiated referendum likely to come up for a national vote in 2020, the "Responsible Business Initiative" (RBI), would introduce strict social and environmental standards for Swiss firms operating abroad. These include due diligence requirements and liability for human rights violations and violations of environmental standards in other countries. We use this upcoming popular vote to credibly present our case to survey respondents (see Section 3 and Appendix Sections A.1.1 and A.1.2). The issue at hand is highly relevant for the Swiss economy, which is home to a large number of multinational enterprises (MNEs, see Ruggie 2018) - corporate groups, which "usually comprise companies or other entities established in more than one country and so linked that they may coordinate their operations in various ways" (OECD 2011, p.17) 1

The empirical analysis produces three key findings. First, we show that information on voluntary social and environmental protection measures by the private sector decreases citizens' support for new government regulation in this area more generally, and for the Responsible Business Initiative specifically. Second, the crowding-out effect is substantial (and significant) w hen h igh-risk fi rms pa rticipate in vo luntary in itiatives, an $\mathrm{d}$ th ere is third-party oversight of such efforts. Third, in contrast to other recent empirical research (Malhotra et al. 2018) we find that the 'breadth' of voluntary initiatives (the share of the

$1 \quad$ MNEs account for around $40 \%$ of Swiss corporate tax revenue and about $11 \%$ of Swiss employment (Walser \& Bischofberger 2013). Moreover, Switzerland is home to roughly 500 companies active in the natural resource business (minerals, agricultural goods, etc.)(Federal Department of Foreign Affairs FDFA 2013), who would be strongly affected by the RBI. 
private sector taking action) matters much less than the involvement of high-risk firms and third-party oversight when displaying sincere and costly efforts to citizens.

The research presented here is relevant both from an academic and a policy perspective. To begin with, not only is there much debate at the international level on how to implement global social and environmental standards, and whether voluntary corporate and sector initiatives are a viable and effective solution (see Falkner 2003, Pope \& Lim 2019), but some norm setters appear to increasingly rely on voluntary corporate initiatives (OECD 2018). On the other hand, however, where new soft law is proposed, voluntary action is often the lowest common denominator under which these norms are adopted (United Nations 2011). Hence it is essential to understand the domestic regulatory game and the public reaction to voluntary business initiatives. Prior research has shown that global norm-setting can influence corporate behaviour if firms can be sanctioned for noncompliant behaviour by their home country (see Jensen \& Malesky 2018). Our research shows, however, that firms also have an incentive to voluntarily subscribe to g lobal minimum standards by voluntarily engaging in social and environmental protection measures if more stringent rules loom at the national level.

This paper proceeds as follows. In the next section, we outline our theoretical argument. We then present the empirical study design, the empirical findings, and conclude with a discussion of these findings and their research and policy implications.

\section{Theory}

We contribute to research on the interplay between corporate behaviour and regulatory action, and, in particular, to an emerging body of literature on the effects of corporate behaviour on citizens' political preferences on regulatory policy (Malhotra et al. 2018). We build on arguments describing the effect of corporate action on politically relevant 
(both governmental and non-governmental) stakeholders to explain how the private sector may influence public opinion (James 2018, Lyon et al. 2018). Furthermore, we investigate conditions, especially the transparency and ensuing credibility of corporate commitments, under which the effect of corporate behaviour on public demand for regulation may be weaker or stronger (Gardner et al. 2019, Lambin et al. 2018).

\subsection{The Interplay between Corporate Behaviour and Regulatory Action}

In academic and policy discussions of firm b ehaviour, o ne c ontroversial i ssue regularly concerns the conditions under which firms are willing and able to engage in appropriate social and environmental behaviour and thus minimise societal externalities of their economic activity. Not surprisingly, a large body of academic and applied research focuses on this issue (Brekke \& Pekovic 2018).

Business interest group representatives often argue that, out of self-interest, most companies do integrate environmental and social concerns into their business strategy voluntarily (Berger et al. 2013, EconomieSuisse 2017, Kinderman 2016, Stöhr \& Michel 2015). This argument is in line with literature that highlights financial incentives as a key driver of sustainable corporate behaviour (Albertini 2013, Endrikat et al. 2014, Flammer 2015, Ziegler et al. 2011). On the one hand, it posits that firm-level sustainability increases competitiveness by increasing effciency of production (Bernauer et al. 2007, Porter \& Van Der Linde 1995, Rexhäuser \& Rammer 2014, Wagner 2003). On the other hand, firm-level sustainability may also increase competitiveness by reducing employees' wage requirements (Bode \& Singh 2018, Burbano 2016) whilst increasing their engagement at work (Carnahan et al. 2017, Flammer \& Luo 2017). Furthermore, if customers value sustainable corporate behaviour, firms may be able to skim consumers' willingness to pay 
for sustainable products(Arora \& Gangopadhyay 1995, Hainmueller et al. 2015). Lastly, from a consumer psychology perspective, sustainable corporate behaviour has been argued to create a stronger, more meaningful relationship between consumers and companies (Alhouti et al. 2016, Babiak \& Trendafilova 2011, Johnson \& Rickard 2017, Bhattacharya \& Sen 2003, Chernev \& Blair 2015, Sen et al. 2016).

Critics contend that sustainable corporate behaviour is more likely to be driven by strategic objectives - such as, e.g. raising potential entry barriers for potential competitors (Barrett 1991, Denicolò 2008, Urpelainen 2011). Yet others argue that sustainable corporate behaviour can serve to preempt government regulation (Lutz et al. 2000, Maxwell et al. 2000, Maxwell \& Decker 2006).

However, not only can sustainable corporate behaviour be understood as a 'signal' (visà-vis regulatory authorities) but it can also serve to legitimise business practices towards a wider group of stakeholders, such as elected politicians, civil society organisations, and citizens (Baron et al. 2011, Daudigeos et al. 2018, Delmas \& Toffel 2008, Konisky 2008). This purpose of sustainable corporate behaviour is often referred to as regulatory or social license to operate (Howard-Grenville et al. 2008). Thus, by carefully constructing a social license to operate or by reframing their business practices, firms may be able to influence their reputation and reap political benefits (Fooks e t a 1. 2013, Hong \& L iskovich 2016, Werner 2015).

\subsection{How Corporate Behaviour Can Affect Public Opinion}

Our arguments focus on how public demand for private sector regulation is affected by voluntary pro-environmental and pro-social initiatives by the very same private sector. We build our causal argument on the literature on regulatory preemption (Baron 2014, Fleckinger \& Glachant 2011, Glachant 2007, Maxwell et al. 2000). Accordingly, we 
base our argument on a framework of decision-making, where public demand for an additional unit of regulation $(\mathrm{R})$ is a function that depends positively on the probability that additional regulation reduces a given risk $(\mathrm{P})$ and negatively on marginal costs of firms for additional units of risk management $(\mathrm{M})$. In turn, $\mathrm{P}$ depends negatively, while $\mathrm{M}$ depends positively, on current firm risk management L, i.e. demand for regulation $R=R(P(L)$, $M(L)$ ). If firms engage in voluntary behaviour and hence shift $\mathrm{L}$, this moves $\mathrm{P}$ downward and M upward - it thus makes any additional unit of regulation ap-pear both less beneficial and more costly. Hence, along the lines of Malhotra et al. (2018), we propose that voluntary measures convey information to the public that a specific issue or problem is being addressed and, at least partially, solved. We, thus, expect that volun-tary private-sector measures crowd out public demand for more government intervention. More specifically, committing to voluntary environmental and social protection measures implies costs for the private sector. We submit that by voluntarily incurring such costs in efforts to protect the environment and employees at production sites, the private sector addresses public concerns over inappropriate environmental or social risks and implies that stricter government-imposed rules regarding that issue are not necessary. In sum, by confronting the problem at hand voluntarily, the private sector seeks to reduce the per-ceived need for regulatory action. Furthermore, once firms have invested in environmental and social protection, citizens might be unwilling to ask for more stringent government regulation which could potentially devalue firms' investments (Malhotra et al. 2018). We thus hypothesise that:

Hypothesis $\mathbf{H}_{\mathbf{1}}$ : Voluntary environmental and social protection measures by the private sector reduce public demand for stricter government regulation.

H1 addresses a mechanism by which firm behaviour affects current risk levels. For 
example, in the particular case of MNE production in low standard countries, the most plausible scenario of private-sector measures is one of reporting. In that case, the private sector would increase transparency and firm-level c omparability, a nd t hus potentially reduce the perceived need for monitoring and further action by the government. This, in turn, lowers the benefits ( or t he n ecessity) of r egulatory a ction a nd h ence decreases demand for regulation.

In the same vein, more socially and environmentally responsible firm behaviour, i.e. more elaborate voluntary firm initiatives, are likely to reduce demand for regulation even further. We call this the substantive extent of voluntary measures. Malhotra et al. (2018) introduce two dimensions in this regard, 'depth' and 'breadth' of voluntary initiatives, i.e. how many firms in a sector engage ('breadth') and whether they engage with extensive programs ('depth').

Similarly, we argue that voluntary action by more firms is likely to affect public opinion more strongly. However, in practical political discourse, debates usually focus on specific sectors or even companies, e.g. as these are called out by civil society watchdog organizations or targeted by government monitors. This is, as firms in different segments of the private sector differ in the levels of risk they pose to people and the environment. For example, Swiss companies in the commodities sector (e.g. minerals, cotton) are prominent targets of criticism related to alleged negative externalities of their business operations abroad. Theoretically, the participation in voluntary action by firms from these sectors combines elements of both breadth and depth. On the one hand, the participation of highrisk sector firms indicates breadth, since it demonstrates commitments by a group of important actors. On the other hand, it shows depth, because the involvement of these firms (i.e. those active in the 'hotspot sectors') is likely to imply a stronger reduc-tion of overall risk levels. Together, this should reduce demand for regulation to a more 
substantial degree.

In sum then, the substantive extent of voluntary measures would increase with breadth (share of the private sector) and with the commitment of high-risk companies, because the latter deals with the issue of environmental and social protection, where action is present (at least perceived to be) most urgently required. We thus hypothesise that:

Hypothesis $\mathbf{H}_{2}$ : Voluntary environmental and social protection measures particularly reduce public demand for regulation if they are implemented by a large share of the private sector.

Hypothesis $\mathbf{H}_{3}$ : Voluntary environmental and social protection measures particularly reduce public demand for regulation if high-risk firms participate in such efforts.

Yet another critical facet of private-sector commitments to corporate responsibility pertains to transparency and oversight, which extends the concept of 'depth' proposed by Malhotra et al. (2018). This is particularly important for extraterritorial firm behaviour, where it is diffcult for citizens to observe outcomes of voluntary private-sector environmental and social protection measures. Due to geographical and cultural distance and an oftentimes low information flow from developing countries, firms have a particular infor-mational advantage, which may incentivise corporations to overstate the environmental and social impact of voluntary measures, misleading the public to develop unduly positive beliefs about corporate environmental and social practices (see Delmas \& Montes-Sancho 2009, Delmas \& Burbano 2011, Lyon \& Montgomery 2015). Aware of such information asymmetry, citizens may be reluctant to update their preferences based on information conveyed by voluntary private-sector environmental and social protection measures. In other words, private sector action might be perceived unreliable by the public unless voluntary measures and their outcomes are made transparent and subject to external 
oversight through an independent organisation (see Gardner et al. 2019, Lambin et al. 2018). However, external oversight, might not only represent a control mechanism over whether firms have complied with a particular standard or target but is likely to include a certain level of public scrutiny with regard to the amount of effort exerted by firms, i.e. the depth of voluntary corporate measures. Hence, we argue that external (third party) oversight increases the reputational stakes of firms that engage in voluntary measures and, thus, indicates a stronger commitment, which in turn increases the credibility of information conveyed to the public (Botero et al. 2015). We, therefore, hypothesise that:

Hypothesis $\mathbf{H}_{\mathbf{4}}$ : Voluntary environmental and social protection measures particularly reduce public demand for regulation if they include third-party oversight.

To summarize, we propose that the private sector's 'signal' to citizens, as conveyed through voluntary environmental and social protection initiatives, can vary along two dimensions: substantive extent and credibility. Substantive extent, in our empirical case, pertains to the breadth of initiatives and inclusion of high-risk companies. Credibility pertains to third-party oversight, in line with previous research pointing to the importance of involving independent actors as watchdogs in voluntary initiatives and to corporate reputational risks (see, e.g. Daudigeos et al. 2018, McDonnell et al. 2015). We expect that stronger voluntary business initiatives along these lines, especially initiatives combining the different factors outlined above, will be more effective in reducing public demand for more government regulation in the respective area.

\section{Case}


The pivotal event within the debate on responsible business conduct within international supply chains in recent years has been the release of the 'UN Guiding Principles on Business and Human Rights' in 2011 (United Nations 2011, Ruggie 2013, 2018). In short, this norm emphasises states' and corporations' duty to protect individuals from human rights infringements caused by economic activity. However, this norm is not tied to any monitoring or enforcement mechanism - states, hence, respond on a purely voluntary basis. See Appendix Section A.1.2 for a more detailed description of the Guiding Principles.

In 2016, in response to a perceived lack of political effort in Switzerland along the lines of the UN Guiding Principles, an alliance of humanitarian and environmental civil society organizations forced (by collecting and submitting Swiss citizens' signatures in favour) a popular referendum (Hofer et al. 2017, Serdült 2014) over a constitutional amendment (the "Responsible Business Initiative", short RBI). On the one hand, this amendment would oblige the Swiss government to enact binding regulation of corporate environmental and social protection efforts, hereby compelling Swiss companies with international supply chains to engage in due diligence reporting. On the other hand, the amendment would make those same companies liable for damages incurred worldwide (as a consequence of inappropriate due diligence) in the course of economic activity within their supply chain. See Appendix Section A.1.1 for the text of the constitutional amendment, which would go far beyond all currently existing regulation of responsible business conduct in Europe. See Appendix Section A.1.1 for details on how the proposed Swiss regulation compares to similar legislation in other European countries.

The referendum demands have been debated in the Swiss parliament extensively between November 2017 and March 2020. See Appendix Section A.1.2 for details on the political process on display here. The latest possible date for a popular referendum to be 
held is in November $2020^{2}$.

\section{Study Design}

Our study design relies on a framing experiment (Chong \& Druckman 2007, Mutz 2011) embedded in a survey on public opinion concerning MNEs based in Switzerland. The survey was implemented from 6-28 November 2018. It was designed by the authors and was fielded through Intervista's o nline panel $3 / 3$ wich is o ne of t he largest o nline survey panels in Switzerlan $\mathrm{d}^{4}$. From this panel, a sample of 3010 Swiss citizens older than 18, and hence eligible to vote, was drawn. We used interlocked quotas on age and gender as well as quotas on education and regional provenance of the participants to make the sample representative of the Swiss voting population with respect to these criteria. The survey was administered in German, French, and Italian (the main languages of the country) and was approved by $(. .$.$) 's IRB. The survey included two separate experiments in which$ each respondent took part. These experiments were assigned in random order. However, in analyzing the data we observed that participating in the experiment which is not the subject of this present paper first, before engaging in the experiment subject of this paper, led to some (albeit minor) biases in the main findings d ue t o o rdering effects. See Appendix Section A.2.2 for a detailed discussion of the survey structure. Our main analysis thus relies primarily on data from those study participants who engaged in the experiment for the present paper first $(\mathrm{N}=1564) \mathrm{b}$ ut $\mathrm{r}$ eport t he r esults f or t he overall

\footnotetext{
2 Seehttps://corporatejustice.ch/ for the pro-campaign website, https:// erpresserische-klagen-nein.ch/ for the contra-campaign website and https://www.bj. admin.ch/bj/de/home/wirtschaft/gesetzgebung/konzernverantwortungsinitiative.html for the government position on the issue (latter two websites not available in English).

3 https://www.intervista.ch/about/?lang=en

4 Empirical evidence Ansolabehere \& Schaffner 2014, Baker et al. 2013) suggests that samples from online panels are comparable to traditional random samples in terms of representativeness and experimental results. In Appendix Section A.2.3 we illustrate the representativity of the sample on the distribution of environmental concern.
} 
sample $(\mathrm{N}=3010)$ in the Appendix for comparison.

\subsection{Dependent Variables}

We recorded study participants' preferences towards regulation with two survey items on 'general' demand for regulation and two survey items measuring support for the Responsible Business Initiative (RBI). First, survey participants were shown two statements and were asked to indicate how much they agree or disagree with each statement on a 5 -point Likert scale. The two statements (presented in randomized order) were (translation from German):

- The Swiss government should supervise and regulate the activities of Swiss companies abroad more closely.

- Voluntary measures by Swiss companies at their locations abroad are sufficient to protect people and the environment there.

We also asked participants to indicate their agreement or disagreement on a 5-point Likert scale concerning a battery of statements aimed at eliciting particular perceptions of voluntary business initiatives (see Appendix Section A.4). These statements measured to what extent participants perceive voluntary initiatives by firms to be trustworthy, costly, and indicative of firms' interest in protecting people and the environment.

We then asked participants about whether they would vote for or against the RBI if the vote were held today. We measured support for the RBI using both a trichotomous item (yes/no/don't know) and a 7-point scale to allow respondents to express in more nuanced form uncertainty in their opinion. Before replying to these questions, the respective vignette texts (see below) were shown again to participants. This was meant to keep the (time) distance between exposure to the vignette and the response similar between our 
dependent variables. We also made sure that participants had a homogeneous level of information about the referendum by displaying a summary of the referendum's contents to all participants before eliciting their preferences.

\subsection{Treatment Design}

We randomly exposed study participants to varying information about voluntary measures by Swiss firms operating abroad. In particular, participants were randomly assigned to one of six groups - a placebo group and five treatment groups. Table 1 provides an overview.

Participants assigned to the placebo group were given a very broadly formulated text stating that different opinions exist about whether new government rules for firms operating in other countries are necessary. We opted for a placebo group instead of a control group receiving no information at all to keep the exposure to the amount of text comparable among respondents. Those assigned to one of the treatment groups were presented with information about voluntary measures by firms. This information varied on two dimensions:

- substantive extent, in particular

- whether the voluntary measures were implemented by most firms or only by a few firms, and

- whether companies dealing with natural resources ('high-risk' firms) participated in the voluntary measures.

- credibility, in particular

- whether there was external oversight by an independent non-profit organisation. 
We ensured that all participants (including the placebo group) were aware that Swiss firms which are active in the commodities sector - e.g. firms that deal with minerals, oil, or agricultural products - are at a higher risk of causing negative environmental and social externalities. We did so by including a short sentence in the introduction to the experiment about the higher risks to humans and the environment in the resource business (see Appendix Section A.2.1). For illustration, the most extensive treatment text (experimentally manipulated components are underlined; translated from German) reads as follows:

The Swiss private sector is already dealing with the issue. Most Swiss companies have voluntarily committed themselves to protect people and the environment at their operating sites abroad to a much greater degree. Specifically, they have promised to issue a comprehensive yearly report on risks to people and the environment and according measures to reduce such risks. This report will be checked by an independent, not-for-profit organisation. The full report and the result of the verification will be published on the internet. Among the participating companies are most Swiss companies involved in commodities (such as gold, copper, oil and gas, coffee, cotton).

As shown in Table 1, we used a fractional factorial design. In particular, we tested all possible combinations of treatment conditions within the group that received a treatment text including the statement that 'most firms' engaged in voluntary initiatives. Additionally, we tested a most likely treatment text for the group that was confronted with the statement that 'only few firms' engaged in voluntary initiatives. The rationale was that, theoretically, within that latter group, we would not expect any other treatment but the treatment of including high-risk firms and NGO monitoring to be able to move 
Table 1: Overview on treatment composition

\begin{tabular}{|l||l|l|l|l|l|l|}
\hline Group & Placebo & 1 & 2 & 3 & 4 & 5 \\
\hline \hline $\begin{array}{l}\text { Do firms engage in } \\
\text { voluntary initiatives? }\end{array}$ & $\begin{array}{l}\text { No } \\
\text { mention }\end{array}$ & Yes & Yes & Yes & Yes & Yes \\
\hline $\begin{array}{l}\text { Most firms or only few } \\
\text { firms? }\end{array}$ & - & $\begin{array}{l}\text { Few } \\
\text { firms }\end{array}$ & $\begin{array}{l}\text { Most } \\
\text { firms }\end{array}$ & $\begin{array}{l}\text { Most } \\
\text { firms }\end{array}$ & $\begin{array}{l}\text { Most } \\
\text { firms }\end{array}$ & $\begin{array}{l}\text { Most } \\
\text { firms }\end{array}$ \\
\hline $\begin{array}{l}\text { Are commodity com- } \\
\text { panies involved? }\end{array}$ & - & Yes & $\begin{array}{l}\text { No } \\
\text { mention }\end{array}$ & $\begin{array}{l}\text { No } \\
\text { mention }\end{array}$ & Yes & Yes \\
\hline $\begin{array}{l}\text { Is the report to be } \\
\text { checked by an NGO? }\end{array}$ & - & Yes & $\begin{array}{l}\text { No } \\
\text { mention }\end{array}$ & Yes & $\begin{array}{l}\text { No } \\
\text { mention }\end{array}$ & Yes \\
\hline
\end{tabular}

respondents' opinions.5 We included our translation of the original German treatment texts in Appendix Section A.2.1.

\subsection{Estimation Strategy}

We analyzed the data by comparing conditional means for the different vignette treatments to our placebo, and also relative to each other. We did so by estimating a linear regression model of the following form:

$$
Y_{n i}=\alpha+\beta_{2} T_{2 i}+\beta_{3} T_{3 i}+\beta_{4} T_{4 i}+\beta_{5} T_{5 i}+\beta_{6} T_{6 i}+\gamma X_{i}+\epsilon_{i}
$$

$Y_{i}$ represents a response by participant $i$ on survey item $n$ (dependent variable). The baseline is the placebo treatment $\left(T_{1}\right)$ (see Table 1 ). Without inclusion of control variables, the constant $\alpha$ can hence be understood as the average response absent any treatment. The coefficients $\beta_{2}$ to $\beta_{6}$ indicate treatment effects for the binary vignette treatments $T_{2}$ to $T_{6}$. We control for a vector of socio-demographic and political control variables $X_{i}$ (see Appendix Table A.13 for results without control variables)

$5 \quad$ I.e., we test here whether review by an NGO and the high-risk sector treatment combined could 'compensate' for lack of participation in the voluntary initiatives.

6 Control variables include respondents' gender, age group, self-evaluation of personal economic situ- 


\section{Results}

We start with the distributions on our main dependent variables before proceeding to the analysis of treatment effects on these variables.

\subsection{Support for Regulatory Action}
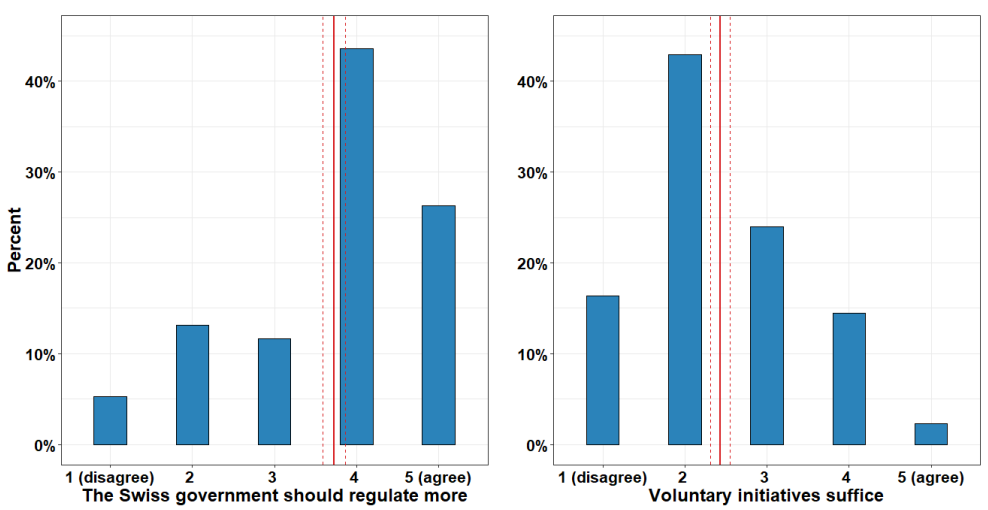

Figure 1: Baseline (i.e. only placebo group) mean and distribution on survey items 'The Swiss government should oversee and regulate the activities of Swiss firms in other countries more strongly.' (left, $\mathrm{N}=266$ ) and 'Voluntary initiatives by Swiss firms to protect humans and the environment at their company locations abroad suffice.' (right, $\mathrm{N}=263$ ). Responses measured on a 5-point Likert scale (5: 'completely agree'; 1 'completely disagree'). The dashed lines report $95 \%$ confidence interval around the means.

Figure 1 displays two histograms for respondent (placebo group) preferences over regulatory action. The left panel presents the distribution of preferences for more state regulation, whereas the right panel shows to what extent study participants perceived voluntary firm measures as sufficient to protect humans and the environment at Swiss firms' operation sites abroad. As can be seen, distributions are lop-sided towards the regulation-friendly sides of the scales, i.e. on average a majority of respondents prefers

ation, education level, employment status, rurality, language, region of Switzerland, self-placement on left-right scale, party ID, and self-stated voting frequency. 
more government intervention and regulation for MNE businesses abroad and disagrees with the statement that voluntary measures by firms suffice.
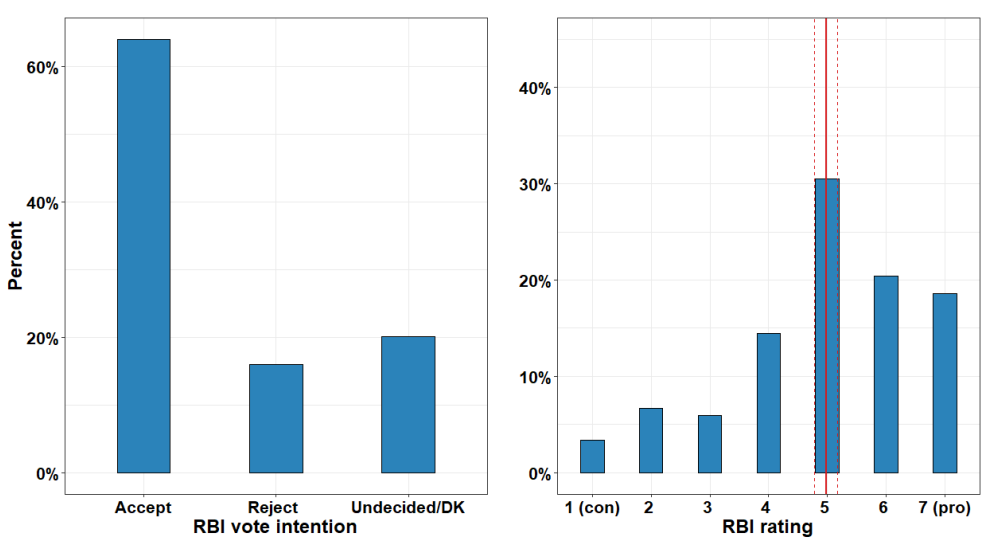

Figure 2: Baseline (i.e. only placebo group) distribution on survey item 'If you were to vote today on the Responsible Business Initiative, how would you vote? I would accept it/reject it/don't know.' (left, $\mathrm{N}=269$ ) and baseline (i.e. only placebo group) mean and distribution on survey item 'On a scale from 1 (totally opposed) to seven (totally in favour), how strongly are you for or against the Responsible Business Initiative?' (right, $\mathrm{N}=269$ ). Responses are measured on a 7 -point Likert scale. The dashed lines report $95 \%$ confidence intervals around the mean.

Figure 2 displays the distribution of public support for the RBI. Asked for for/againstvoting intentions, around $64 \%$ of participants would support the RBI (no: 16\%; don't know: 20\%) (see Figure 2, left panel). Similarly, on a 7-point-scale, average responses are tilted towards higher scores and hence more favourable opinions on the RBI (see Figure 2 right panel) ${ }^{7}$

$7 \quad$ Given that the vote is scheduled only for 2020, the large share of 'don't know'-responses is a reflection of, at the time of the survey field time in November 2018, still modest levels of public attention and campaigning. 


\subsection{How Voluntary Corporate Initiatives Affect Support for Gov- ernment Action}

\subsubsection{Overall Effect of Voluntary Initiatives}

Hypothesis $\mathrm{H}_{1}$ posits that information about voluntary environmental and social protection measures by the private sector reduces public demand for regulation. Indeed, we observe that our treatments have negative effects on respondents' regulatory preferences as measured by our dependent variables (both regulatory support and RBI rating/support). Pooling all our treatment conditions and comparing them to the placebo group (see Appendix Table A.2, we observe that respondents are less likely to agree that the state should be regulating Swiss firms abroad (decrease of 0.13 on a 5 -point-scale, $3.5 \%$ of the placebo group mean, significant at the $10 \%$ level), that respondents are more likely to agree that voluntary measures are sufficient (increase of 0.17 on a 5 -point-scale, $7 \%$ of the placebo group mean, significant at the 5\%-level), and that respondents are less likely to support the RBI (decreased rating by 0.22 on a 7 -point-scale, $4.4 \%$ of the placebo group mean, significant at the 5\%-level; decrease of yes-share by 6 percentage points, $9.4 \%$ of control group mean, significant at the $10 \%$ level; increase of no-share by 6 percentage points, $37.5 \%$ of control group mean, significant at the $5 \%$-level).

\subsubsection{Effects of Substantive Extent and Credibility of Voluntary Initiatives}

Hypothesis $\mathrm{H}_{2}$ and $\mathrm{H}_{3}$ suggest that if the treatment text about voluntary initiatives by firms contains information about the participation of a large share of the private sector $\left(\mathrm{H}_{2}\right)$ or about commitments by high-risk companies $\left(\mathrm{H}_{3}\right)$, public demand for regulation is likely to decrease. Similarly, in Hypothesis $\mathrm{H}_{4}$, we argue that if external oversight is part of the voluntary environmental and social protection measures by the private sector, 
public demand for regulation is likely to decrease.

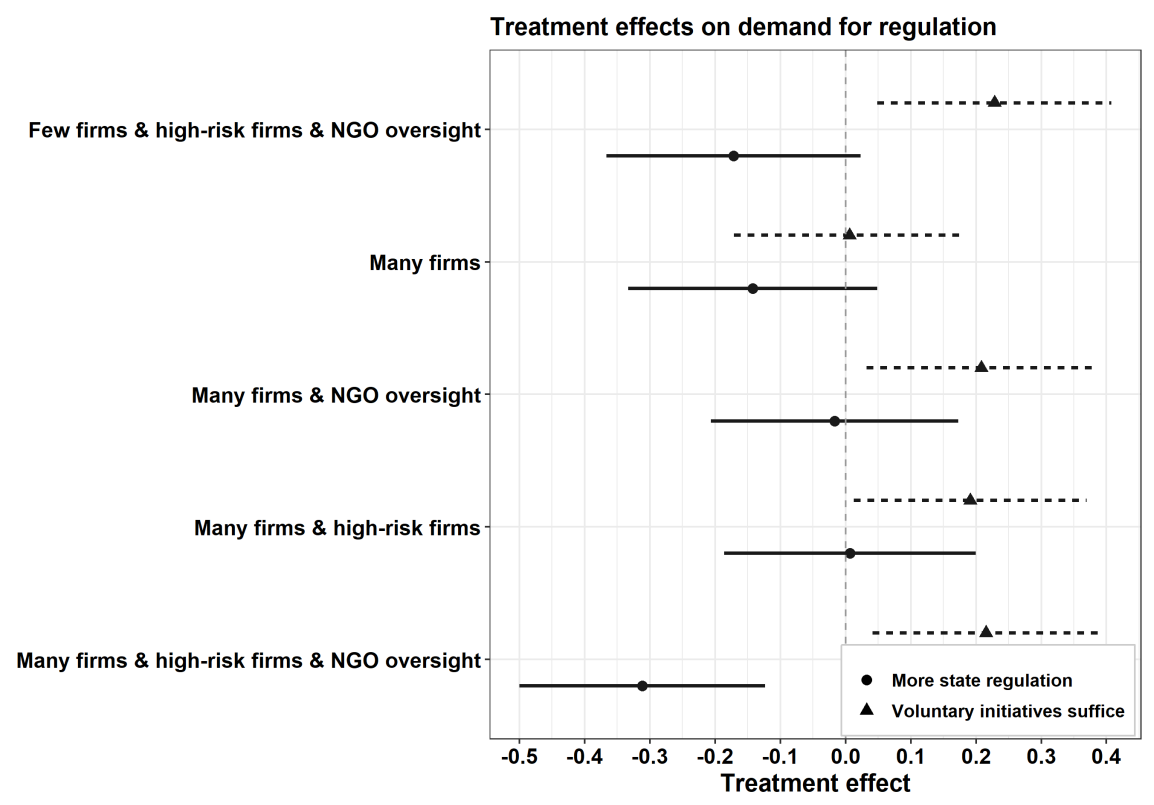

Figure 3: Estimates of treatment effects of vignette conditions relative to the placebo group on the outcome variable 'more state regulation' (item wording: 'The Swiss state should oversee and regulate the activities of Swiss firms in other countries more strongly.') (circles, $\mathrm{N}=1456$ ) and on the outcome variable 'voluntary initiatives suffice' (item wording: 'Voluntary initiatives by Swiss firms to protect humans and the environment at their company locations abroad suffice.') (triangles, $\mathrm{N}=1420$ ). Responses measured on a 5 -point Likert scale (5: 'completely agree'; 1 'completely disagree'). Whiskers report $95 \%$ confidence intervals. The regression includes socio-demographic and political controls. Full results are reported in Appendix Table A.12.

As can be seen from Figures 3 and 4 we observe that a combined vignette highlighting broad participation, inclusion of high-risk firms, and NGO oversight (many, risk, NGOvignette) has the strongest effect on respondents' opinions (see Figure 3). With this combination of treatments in the vignette, preferences for more regulation decrease by about 0.31 on the 5 -point regulatory preference scale, and the perception of the sufficiency of voluntary initiatives increases by about 0.21 on the same scale (see Figure 3 ). At the same time, the rating of RBI approval decreases by about 0.43 on the 7 -point approval 


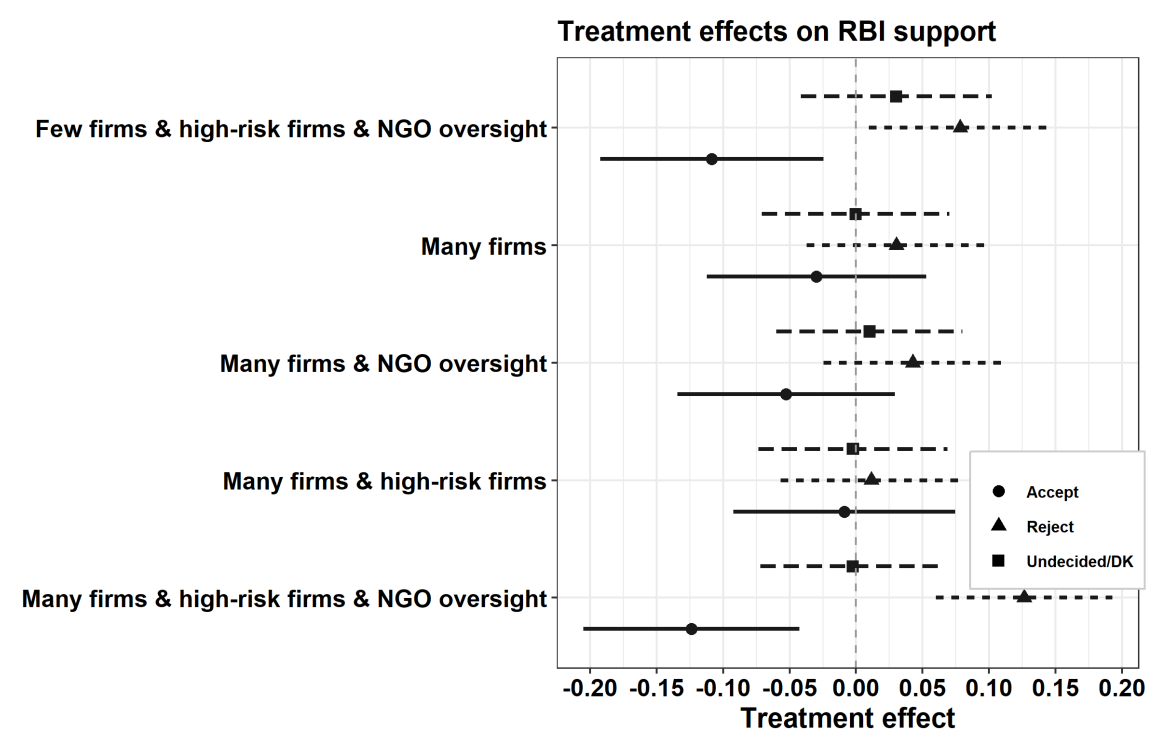

Figure 4: Estimates of treatment effects of vignette conditions relative to the placebo group on the outcome variable 'RBI support' (item wording: 'If you were to vote today on the Responsible Business Initiative, how would you vote? I would accept it/reject it/don't know.' (accept: circles; reject: triangles; don't know: squares, $\mathrm{N}=1472$ ). Whiskers report 95\% confidence intervals. The regression includes socio-demographic and political control variables. Full results are reported in Appendix Table A.12.

scale (see Appendix Figure A.16). Substantively, these results are about the size of one-quarter of a standard deviation. A substantial shift is apparent for the RBI yes share (see Figure 4): it decreases by about 12 percentage points (significant at the 1\%level). The vignette that highlights the inclusion of high-risk firms and NGO oversight despite participation by only some firms (few, risk, NGO-vignette), consistently alters respondents' opinions, albeit to a lesser extent compared to the many, risk, NGO-vignette (see Figure 4). One additional noteworthy finding is that the many, risk, NGO-vignette shifts responses from the RBI-yes share to the RBI-no option, the few, risk, NGO-vignette shifts yes-replies towards both no- and don't know answer categories (see Figure 4). Hence, where only some firms take voluntary action, some respondents seem to be insecure about how to interpret this signal. 
All other vignettes - many, no risk, no NGO, many, risk, no NGO, many, no risk, $N G O$ - move respondents' opinions into the expected direction, albeit to a much smaller extent. Only for the item 'are voluntary measures sufficient' do opinions shift in a statistically significant way for the many, risk, no NGO-vignette and the many, no risk, $N G O$-vignette. On the other outcome variables, treatment effects do not reach conventional levels of statistical significance. Importantly, when comparing treatment conditions among each-other, treatment coefficients for the many, risk, $N G O$-vignette are in many cases substantially and significantly stronger compared to the many/many, risk/many, $N G O$-vignettes.

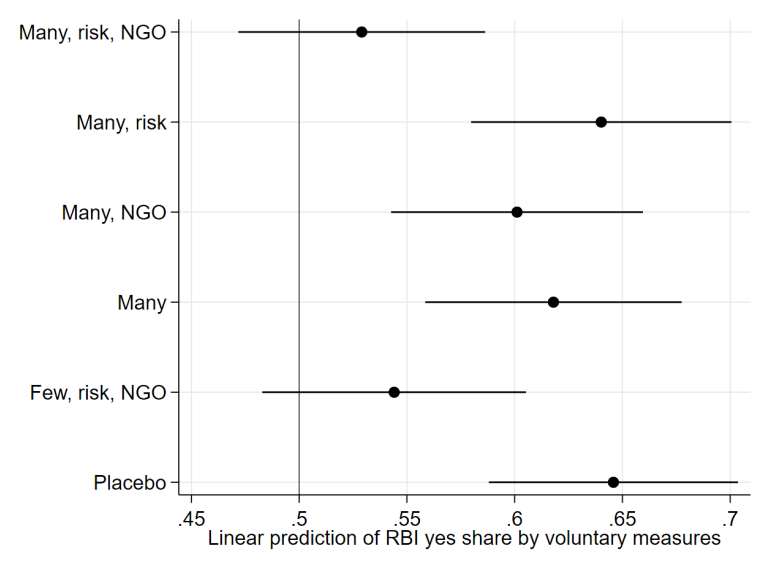

Figure 5: Predictions of RBI support, i.e. share of respondents who would accept the RBI (item wording: 'If you were to vote today on the Responsible Business Initiative, how would you vote? I would accept it/reject it/don't know.' $(\mathrm{N}=1564)$ ), given the differing vignette conditions including the placebo. Whiskers report $95 \%$ confidence intervals. The regression includes sociodemographic and political control variables, as reported in Appendix Table A.12.

Our findings have important implications for policy and the RBI in particular. As noted above (see Figure 22), absent any information on voluntary firm action, the yes share (vs the no share and the 'don't know/undecided' share) exceeds $60 \%$. However, our estimation results (see Figure 44 suggest that voluntary corporate behaviour reduces 
public support towards the point of tipping the balance against the RBI in a referendum. This interpretation follows directly from predicted RBI support, given the different vignettes (see Figure 5). Specifically, w e o bserve that o nly the p redicted values of public support for the many, risk, NGO and the few, risk, NGO-vignettes - both around 54\% - are significantly b elow the p lacebo g roup value of $64 \%$. M ost n otably, the confidence interval for these predicted values crosses the $50 \%$ mark and thus underlines the shift of respondents' policy preferences into a competitive realm around the majority threshold.

Given these results, based on survey items recording respondents' attitudes towards voluntary corporate initiatives, we examined why our treatments conditions were (not) able to affect respondents' regulatory preferences. Appendix Table A.7 summarizes our findings, w hich i ndicate t hat v oluntary c orporate i nitiatives i ndeed c onvey a stronger message when both risk-firms and N GO o versight a re i ncluded. H owever, d ue t o small coecient sizes and low statistical power, these tests do not allow for definite conclusions. In sum, our results here suggest first, that to have a meaningful impact on public opinion, corporate self-regulation must combine several conditions and second, that study participants discern the nuances of differing voluntary business initiatives. They are affected in their regulatory preferences only by strong corporate commitments.

\subsubsection{Subgroup Effects}

As recommended by Mutz (2011), we exploit one of the major advantages of a populationbased survey experiment and assess how regulatory preferences vary across different types of voters/citizens. In order to test for interactions between respondent characteristics and corporate behaviour vignettes, we stratify the primary analysis by binarized indicator variables for respondent's (self-reported) voting probability, political interest, prior knowledge of the RBI, environmental concern, political ideology, as well as age, gender, education, in- 
come, employment status, cultural background (French/Italian vs German-speaking part of Switzerland), settlement type of household location (urban/rural) and, last but not least, survey time (results are presented and discussed in detail in Appendix Section A.3). Note that this is a mainly explanatory analysis based on the variables available to us from our survey instrument. We, therefore, refrain from strong interpretations of these patterns but think they are highly useful for future research, as well as for policymakers, as they provide some indications for which respondents the crowding-out effect is par-ticularly relevant. Overall, we find that the effects of the vignettes are broadly similar across most of the different subgroups, which is important for the external validity of our findings. However, we observe some notable exceptions.

First, with respect to the strength of treatment effects, respondents with a high probability of voting (i.e. they report usually voting in four out of four annual voting days for federal-level elections and referenda in Switzerland as opposed to zero to three) respond much more strongly to the vignettes compared to the full sample (see Appendix Table A.5). In that case, the shift of vote intentions from yes to no occurs for the many, risk, NGO and the few, risk, NGO-vignettes and is with 17 percentage points both substan-tial (25\% of control group means) and highly significant. In contrast, the low-voting-probability group is not moved by the vignette texts relative to the placebo group. These results show that our findings are driven by the particular subgroup of relatively more politicised (and probably also politically more informed) citizens who are most likely to take part in actual decision-making. As noted in Appendix Table A.9, this subgroup also reacts strongly with respect to our mechanism tests: Specifically, participants in that sub-group are more likely to perceive voluntary measures as costly action after we have shown them the few/many, risk, NGO corporate behaviour vignettes, and they see voluntary measures as an indication of caring firms after having read the few, risk, NGO-vignette 
(relative to the control group). Why exactly this is the case, we propose to be a valuable avenue for future research, i.e. what kind of evaluations of firm behaviour do change with voluntary measures.

Second, respondents from various particular subgroups are more susceptible to a crowding-out of their demand for regulation. While these differences are within the groups only statistically significant for one or two of the presented vignettes each, they are indicative of differing patterns of support. This is the case for respondents with/that are: a high (as opposed to low) environmental concern score; females as opposed to males; low as opposed to high education; below median as opposed to above median income; not in formal (self-)employment as opposed to those (self-)employed; in rural/agglomeration as opposed to urban settlement areas; below median vignette screen survey time as opposed to above median screen time. As well, we find some indication that respondents who have already heard of the RBI react with a higher demand for regulation to the many-vignette. Appendix Section A.3 discusses this finding further.

Third, concerning baseline support for government regulation, among the groups mentioned above high probability voters, respondents with high environmental concern, with a left political ideology, below median household income, not (self-)employed, and females report higher baseline support in the control group.

Taken together, this pattern would imply that A) crowding out is stronger where baseline support is higher and B) that crowding out is taking place with subgroups that are less privileged within the political/social system (low education, low income, females, rural populations). This provides an important avenue for future research around the question whether the other respondents do not react as strongly to the presented treatment vignettes because of more nuanced prior beliefs, and/or whether they did not perceive the presented treatment texts to be credible enough. 


\subsubsection{Robustness}

For additional insight, we submitted our analysis to a series of robustness checks. Our estimation strategy, as reported in previous sections, includes control variables to account for minor imbalances in the distribution of covariates between the groups (see Appendix Table A.11. Nevertheless, we also estimated the effect of our treatment conditions on study participants' regulatory preferences without including any other variables besides our treatment conditions in the models. Overall, we found only small differences in estimated treatment effects between models with and without control variables (see Appendix Table A.13). The outcomes of these estimations, as well as a discussion thereof, are included in Appendix Section A.5.

As recommended by Mutz (2011), we as well used a more robust measurement of our concept of demand for regulation: an indicator variable from a PCA dimension reduction on our two RBI-related crowding-out measures, the RBI rating and RBI yes/no voting indicator. While this measure cannot be readily interpreted directly in absolute terms, it is less prone to measurement error compared to a single Likert scale item. As reported in Appendix Figure A.15, our treatment effects for the few/many, risk and NGO treatment vignettes are estimated substantially large, at about $30 \%$ of a control-group standard deviation, and significant at the 1\%-level using this approach as well.

Furthermore, we checked the robustness of our results with regard to the multiple comparisons problem, which might arise when testing multiple hypotheses on the same data sample and as a consequence of which, p-values not reporting the true probability of committing a type-1 error (Benjamini 2010, Nakagawa 2004, Perneger 1998). We implemented the procedure pioneered by Benjamini \& Hochberg (1995) to adjust our p-values such as to reflect this issue and, hence, depict the statistical significance of our findings more accurately (see Appendix Section A.5). On the whole, the comparison 
of the p-values pre- and post adjustment shows that the estimated treatment effects induced by the many, risk, NGO-vignette can be interpreted as robust. Concerning the few, risk, NGO-vignette, such strong conclusions cannot be drawn. Hence, it seems that voluntary corporate initiatives mainly reduce support for government regulation of corporate behaviour abroad if they combine broad corporate participation (from high-risk sectors as well) with external oversight. See Appendix Tables A.14 to A.19 where we compare the 'raw' and adjusted p-values.

\section{Discussion}

We examine in this paper whether voluntary corporate action affects public demand for the regulation of corporate behaviour. We study this question for the case of extraterritorial environmental and social impacts, i.e. impacts of firm operations in other countries. We hence link to a politically highly relevant debate concerning the implementation of the UN Guiding Principles for Business and Human Rights. Theoretically, we contribute by examining whether and which specific type of private sector engagement crowds out public demand for regulation. We theoretically argue that such preemptive corporate action takes away perceived pressure to act in society.

The existing literature has put forward various arguments on why firms may choose to improve on their environmental and social impacts in the absence of stringent regulation. We are concerned with a line of research that focuses on the strategic (Delmas \& Toffel 2008, Lutz et al. 2000) and political reasons (Baron 2014, Werner 2015) for why firms engage in such behaviour.

Whether explicitly intended or not, voluntary corporate initiatives are likely to convey information about corporate behaviour towards the mass public (and also other political stakeholders) and may thus influence public demand for changes to the status quo 
of government regulation. We argued that by voluntarily incurring a cost in efforts to engage in socially and environmentally more sustainable business operations, firms might demonstrate citizens that stricter government-imposed rules are not necessary. We also argued that voluntary corporate responsibility measures vary in strength (and thus impact public demand) with three general characteristics: first, the share of the private sector ('breadth') associated with the measures; second, the type of firms committing to voluntary measures; and third, external oversight (which enhances credibility due to increased reputational costs of non-compliance with self-imposed standards).

Based on a vignette survey experiment with a representative sample of Swiss citizens of voting age, we focus on a case where citizens are actually scheduled to vote in a national referendum on the subject of our study. The main question in this referendum is whether voluntary self-regulation is suffcient for coping with environmental and social impacts of Swiss firms abroad, or whether new government regulation is needed. Compared to many other survey experiments on corporate social responsibility issues, which rely on hypothetical scenarios, this real-life setting makes our study empirically realistic and policy-relevant. More specifically, the connection to an actual policy debate allowed us to model our survey-experimental setup, and in particular, our treatments, based on claims made 'in the real world' about voluntary corporate environmental and social protection efforts (see, e.g., DeCarli 2019, Scherrer 2017, Stöhr \& Michel 2015).

Although our study, thus, is nested within one country case, we propose it provides valuable inputs to public policy (research) beyond that particular context for three reasons. First, other European countries and the European Union currently debate stricter regulation of supply chains of domestic firms (not restricted to particular sectors) abroad (Augenstein et al. 2018, European Parliament 2020, Working Group on Responsible Business Conduct 2019, Zacharakis 2019). Second, Switzerland is a small open economy and 
MNEs are highly relevant for the country - hence, we assess a case where corporate behaviour and the regulation thereof are economically relevant to respondents (Walser \& Bischofberger 2013). Finally, Switzerland is comparable to its European neighbours with regard to its GDP per capita (International Monetary Fund 2018) as well as with regard to the strength of green parties in parliament. Thus, while we do not want to extrapolate beyond our Swiss sample, as economic and post-materialist considerations most likely determine public opinion on the matter it seems sensible to expect similar opinion formation processes in Switzerland and other Western European countries (Allendoerfer 2017, Diekmann 1999, Diekmann \& Preisendörfer 2003, Steg 2016).

Our analysis shows that voluntary initiatives do reduce public support for new and stricter government regulation of corporate environmental and social behaviour abroad. In what is likely to be the most policy-relevant finding, voluntary initiatives characterized by involvement of critical parts of the private sector and third-party oversight have the potential of reducing support for new government regulation from around $60 \%$ down to the tipping point of around 50\%. Whether voluntary initiatives involve broad or narrow participation of the respective industry, as such, makes less of a difference as long as critical actors participate and submit to third party monitoring.

Given the economic stakes and the sincerity of the decision making context, one might have expected that citizens are reluctant to regulate business, and rather lenient in accepting voluntary corporate programs as a solution. In comparison to Malhotra et al. (2018), it is surprising that citizens want to regulate companies more strongly and only react to the most ambitious voluntary corporate programs. Research in other European countries could investigate why this is the case, and whether the extraterritorial nature of the question at hand and/or the context and/or the formulation and presentation of vignettes drives these differences. Overall, still, we would expect for the broader Eu- 
ropean context and the political debate on extraterritorial supply chain oversight that Western-European citizens are willing to regulate corporations.

With rapidly progressing internationalisation of production and consumption, and ever longer and more complex supply chains, the issue of how to deal with social and environmental impacts of home country firms abroad has moved high up on national and international social, trade, and environmental policy agendas (e.g. Alig et al. 2019). Policymakers in wealthy democratic countries are now at the centre of a heated debate among different stakeholders about whether and how to implement more stringent busi-ness conduct standards for firms under their jurisdiction. As the case of Switzerland and the citizen-initiated "Responsible Business Initiative" shows, identifying and implementing policies in this area that are both effective and politically feasible is a challenging task. A better understanding of the incentives and all potential strategic options of stakeholders is, however, a crucial part of this process.

Finally, our arguments and empirical findings can also inform norm-setting debates at the international and global level. The United Nations and other institutions have issued a plethora of new standards over the past years, demanding stricter due diligence from companies with respect to human rights and the environment. Most companies and governments have a responsibility to implement these standards. Such efforts to regulate, or at least monitor, extraterritorial production and sourcing are unfolding in a policy realm that has thus far paid most attention to issues other than social and environ-mental impacts. Our results show that the (Swiss) public supports these recent efforts. They also show that voluntary corporate measures are seen as an important part of the standardsetting and standard implementation effort. Moreover, if the public supports these national standard-setting efforts to the extent we find, corporate actors will also have incentives to comply with global standards voluntarily and to engage in interna- 
tional industry programs to avoid more stringent regulation at the national level. Further research should thus investigate in more detail the factors driving public opinion towards multi-stakeholder programs (e.g. the Alliance for Responsible Mining or the Greenhouse Gas Protocol) and the role for voluntary corporate initiatives within national legislative frameworks especially concerning the implementation of international standards for business conduct.

\section{References}

Abbott, K. W. \& Snidal, D. (2001), 'International 'standards' and international governance', Journal of European Public Policy 8(3), 345-370.

Aklin, M. (2016), 'Re-exploring the Trade and Environment Nexus Through the Diffusion of Pollution', Environmental and Resource Economics 64(4), 663-682.

Albertini, E. (2013), 'Does Environmental Management Improve Financial Performance? A Meta-Analytical Review', Organization \& Environment 26(4), 431-457.

Alhouti, S., Johnson, C. M. \& Holloway, B. B. (2016), 'Corporate social responsibility authenticity: Investigating its antecedents and outcomes', Journal of Business Research 69(3), 1242-1249.

Alig, M., Nathani, C. \& Flury, C. (2019), Umweltauswirkungen einer Marktöffnung im Landwirtschaftsbereich - Analyse drei theoretischer Handelsszenarien, Schlussbericht im Auftrag des Bundesamtes für Umwelt, Federal Office for the Environment FOEN.

Allendoerfer, M. G. (2017), 'Who cares about human rights? Public opinion about human rights foreign policy', Journal of Human Rights 16(4), 428-451. 
Ansolabehere, S. \& Schaffner, B. F. (2014), 'Does Survey Mode Still Matter? Findings from a 2010 Multi-Mode Comparison', Political Analysis 22(3), 285-303.

Arora, S. \& Gangopadhyay, S. (1995), 'Toward a theoretical model of voluntary overcompliance', Journal of Economic Behavior and Organization 28(3), 289-309.

Augenstein, D., Dawson, M. \& Thielbörger, P. (2018), 'The UNGPs in the European Union: The Open Coordination of Business and Human Rights?', Business and Human Rights Journal 3(1), 1-22.

Babiak, K. \& Trendafilova, S. (2011), 'CSR and Environmental Responsibility: Motives and Pressures to Adopt Green Management Practices', Corporate Social Responsibility and Environmental Management 18, 11-24.

Baker, R., Brick, J. M., Bates, N. A., Battaglia, M., Couper, M. P., Dever, J. A., Gile, K. J. \& Tourangeau, R. (2013), 'Summary Report of the AAPOR Task Force on Nonprobability Sampling', Journal of Survey Statistics and Methodology 1(2), 90-143.

Baron, D. P. (2014), 'Self-Regulation in Private and Public Politics', Quarterly Journal of Political Science 9(2), 231-267.

Baron, D. P., Agus Harjoto, M. \& Jo, H. (2011), 'The Economics and Politics of Corporate Social Performance', Business and Politics 13(2), 1-46.

Barrett, S. (1991), 'Environmental Regulation For Competitive Advantage', Business Strategy Review 2(1), 1-15.

Benjamini, Y. (2010), 'Simultaneous and selective inference: Current successes and future challenges', Biometrical Journal 52(6), 708-721. 
Benjamini, Y. \& Hochberg, Y. (1995), 'Controlling the False Discovery Rate: A Practical and Powerful Approach to Multiple Testing', Journal of the Royal Statistical Society: Series B (Methodological) 57(1), 289-300.

Berger, V., Winistörfer, H., Weissert, S., Helm, E. \& Schüz, M. (2013), Swiss Corporate Sustainability Survey 2012 Nachhaltigkeit in Schweizer Unternehmen, Technical report, Zürcher Hochschule für Angewandte Wissenschaften, Winterthur.

Bernauer, T., Kammerer, D. \& Sejas, J. (2007), 'Determinants of Green Innovation - Ten Years after Porter's Win-Win Proposition: How to Study the Effects of Environmental Regulation?', Politische Vierteljahresschrift 39, 323-341.

Bhattacharya, C. \& Sen, S. (2003), 'Consumer-Company Identification: A Framework for Understanding Consumers' Relationships with Companies', Journal of Marketing 67(2), $76-88$.

Bode, C. \& Singh, J. (2018), 'Taking a hit to save the world? E mployee participation in a corporate social initiative', Strategic Management Journal 39(4), 1003-1030.

Botero, S., Cornejo, R. C., Gamboa, L., Pavao, N. \& Nickerson, D. W. (2015), 'Says Who? An Experiment on Allegations of Corruption and Credibility of Sources', Political Research Quarterly 68(3), 493-504.

Brekke, K. A. \& Pekovic, S. (2018), 'Why Are Firms Environmentally Responsible? A Review and Assessment of the Main Mechanisms', International Review of Environmental and Resource Economics 12(4), 355-398.

Buchanan, J. M. \& Stubblebine, W. C. (1962), 'Externality', Economica 29(116), 371.

Burbano, V. C. (2016), 'Social Responsibility Messages and Worker Wage Requirements: 
Field Experimental Evidence from Online Labor Marketplaces', Organization Science 27(4), 1010-1028.

Carnahan, S., Kryscynski, D. \& Olson, D. (2017), 'When Does Corporate Social Responsibility Reduce Employee Turnover? Evidence from Attorneys Before and After 9/11', Academy of Management Journal 60(5), 1932-1962.

Chernev, A. \& Blair, S. (2015), 'Doing Well by Doing Good: The Benevolent Halo of Corporate Social Responsibility', Journal of Consumer Research 41(6), 1412-1425.

Chong, D. \& Druckman, J. N. (2007), 'Framing Theory', Annual Review of Political Science 10(1), 103-126.

Daudigeos, T., Roulet, T. \& Valiorgue, B. (2018), 'How Scandals Act as Catalysts of Fringe Stakeholders' Contentious Actions Against Multinational Corporations', Business \& Society pp. 1-32.

DeCarli, L. (2019), 'Und dann zeigt die ganze Welt mit dem Finger auf ein Unternehmen', TagesAnzeiger .

Delmas, M. A. \& Burbano, V. C. (2011), 'The Drivers of Greenwashing', California Management Review 54(1), 64-87.

Delmas, M. A. \& Montes-Sancho, M. J. (2009), 'Voluntary agreements to improve environmental quality: Symbolic and substantive cooperation', Strategic Management Journal 31(6), 575-601.

Delmas, M. A. \& Toffel, M. W. (2008), 'Organizational responses to environmental demands: Opening the black box', Strategic Management Journal 29(10), 1027-1055. 
Denicolò, V. (2008), 'A signaling model of environmental overcompliance', Journal of Economic Behavior and Organization 68(1), 293-303.

Diekmann, A. (1999), 'The Wealth of Nations and Environmental Concern', Environment and Behavior 31(4), 540-549.

Diekmann, A. \& Preisendörfer, P. (2003), 'Green and Greenback- The behavioral effect of environmental attitudes in low- and high cost situations', Rationality and Society 15(4), 441-472.

EconomieSuisse (2017), 'Unternehmens-Verantwortungs-Initiative schadet ihrem eigenen Ziel', https://www.economiesuisse.ch/de/artikel/konzern-initiative-schadet-ihremeigenen-ziel.

Endrikat, J., Guenther, E. \& Hoppe, H. (2014), 'Making sense of conflicting empirical findings: A meta-analytic review of the relationship between corporate environmental and financial performance', European Management Journal 32(5), 735-751.

European Parliament (2020), Annual report 2018 on the human rights and democracy in the world and the European Union's policy on the matter, Technical report, Brussels.

Falkner, R. (2003), 'Private Environmental Governance and International Relations: Exploring the Links', Global Environmental Politics 3(2), 72-87.

Federal Department of Foreign Affairs FDFA (2013), Commodities. Report of the interdepartamental platform on commodities to the Federal Council, Technical report.

Federal Foreign Office (2016), 'National Action Plan Implementation of the UN Guiding Principles on Business and Human Rights'. 
Flammer, C. (2015), 'Does Corporate Social Responsibility Lead to Superior Financial Performance? A Regression Discontinuity Approach', Management Science 61(11), 2549-2568.

Flammer, C. \& Luo, J. (2017), 'Corporate social responsibility as an employee governance tool: Evidence from a quasi-experiment: CSR as an Employee Governance Tool', Strategic Management Journal 38(2), 163-183.

Fleckinger, P. \& Glachant, M. (2011), 'Negotiating a voluntary agreement when firms self-regulate', Journal of Environmental Economics and Management 62(1), 41-52.

Fooks, G., Gilmore, A., Collin, J., Holden, C. \& Lee, K. (2013), 'The Limits of Corporate Social Responsibility: Techniques of Neutralization, Stakeholder Management and Political CSR', Journal of Business Ethics 112(2), 283-299.

Gardner, T., Benzie, M., Börner, J., Dawkins, E., Fick, S., Garrett, R., Godar, J., Grimard, A., Lake, S., Larsen, R., Mardas, N., McDermott, C., Meyfroidt, P., Osbeck, M., Persson, M., Sembres, T., Suavet, C., Strassburg, B., Trevisan, A., West, C. \& Wolvekamp, P. (2019), 'Transparency and sustainability in global commodity supply chains', World Development 121, 163-177.

Glachant, M. (2007), 'Non-binding voluntary agreements', Journal of Environmental Economics and Management 54(1), 32-48.

Hainmueller, J., Hiscox, M. J. \& Sequeira, S. (2015), 'Consumer Demand for Fair Trade: Evidence from a Multistore Field Experiment', Review of Economics and Statistics 97(2), 242-256.

Hecking, C. (2017), Deutsche Firmen missachten Menschenrechte im Ausland, Online Bericht, Spiegel. 
Hofer, K. E., Marti, C. \& Bütler, M. (2017), 'Ready to reform: How popular initiatives can be successful', European Journal of Political Economy 48, 16-39.

Hong, H. G. \& Liskovich, I. (2016), 'Crime, Punishment and the Value of Corporate Social Responsibility', SSRN Electronic Journal .

Howard-Grenville, J., Nash, J. \& Coglianese, C. (2008), 'Constructing the License to Operate: Internal Factors and Their Influence on Corporate Environmental Decisions', Law \& Policy 30(1), 73-107.

International Monetary Fund (2018), 'World Economic Outlook Database'.

James, S. (2018), 'The structural-informational power of business: Credibility, signalling and the UK banking reform process', Journal of European Public Policy 25(11), 16291647.

Jensen, N. M. \& Malesky, E. J. (2018), 'Nonstate Actors and Compliance with International Agreements: An Empirical Analysis of the OECD Anti-Bribery Convention', International Organization 72(1), 33-69.

Johnson, T. \& Rickard, V. (2017), 'United Nations, Uniting Nations: International Support Cues and American Attitudes on Environmental Sustainability*, Social Science Quarterly 98(3), 876-893.

Kaplan, D. M. (2019), 'distcomp: Comparing distributions', The Stata Journal $\mathbf{1 9}(4), 832-848$.

Kinderman, D. (2016), 'Time for a reality check: Is business willing to support a smart mix of complementary regulation in private governance?', Policy and Society 35(1), 29-42. 
Koch, M. (2018), DGB wirft Bundesregierung mangelnden Einsatz für Menschenrechte vor, Technical report, Handelsblatt.

Konisky, D. M. (2008), 'Bureaucratic and Public Attitudes toward Environmental Regulation and the Economy', State and Local Government Review 40(3), 139-149.

Lambin, E. F., Gibbs, H. K., Heilmayr, R., Carlson, K. M., Fleck, L. C., Garrett, R. D., le Polain de Waroux, Y., McDermott, C. L., McLaughlin, D., Newton, P., Nolte, C., Pacheco, P., Rausch, L. L., Streck, C., Thorlakson, T. \& Walker, N. F. (2018), 'The role of supply-chain initiatives in reducing deforestation', Nature Climate Change 8(2), 109116.

Locke, R. M. (2013), The Promise and Limits of Private Power: Promoting Labor Standards in a Global Economy, Cambridge University Press, Cambridge.

Lutter, S., Pfister, S., Giljum, S., Wieland, H. \& Mutel, C. (2016), 'Spatially explicit assessment of water embodied in European trade: A product-level multi-regional inputoutput analysis', Global Environmental Change 38, 171-182.

Lutz, S., Lyon, T. P. \& Maxwell, J. W. (2000), 'Quality Leadership When Regulatory Standards Are Forthcoming', The Journal of Industrial Economics 48(3), 331-348.

Lyon, T. P., Delmas, M. A., Maxwell, J. W., Bansal, P., Chiroleu-Assouline, M., Crifo, P., Durand, R., Gond, J.-P., King, A., Lenox, M., Toffel, M., Vogel, D. \& Wijen, F. (2018), 'CSR Needs CPR: Corporate Sustainability and Politics', California Management Review 60(4), 5-24.

Lyon, T. P. \& Montgomery, A. W. (2015), 'The Means and End of Greenwash', Organization and Environment 28(2), 223-249. 
Malhotra, N., Monin, B. \& Tomz, M. (2018), 'Does Private Regulation Preempt Public Regulation?', American Political Science Review pp. 1-19.

Maxwell, J. W. \& Decker, C. S. (2006), 'Voluntary environmental investment and responsive regulation', Environmental and Resource Economics 33(4), 425-439.

Maxwell, J. W., Lyon, T. P. \& Hackett, S. C. (2000), 'Self Regulation and Social Welfare: The Political Economy of Corporate Environmentalism', The Journal of Law and Economics 43(2), 583-618.

McDonnell, M.-H., King, B. G. \& Soule, S. A. (2015), 'A Dynamic Process Model of Private Politics: Activist Targeting and Corporate Receptivity to Social Challenges', American Sociological Review 80(3), 654-678.

Meyer, N. (2013), 'Political contestation of self-regulation in the shadow of hierarchy', Journal of European Public Policy 20(5), 760-776.

Mutz, D. C. (2011), Population Based Survey Experiments, Princeton University Press, Princeton.

Nakagawa, S. (2004), 'A farewell to Bonferroni: The problems of low statistical power and publication bias', Behavioral Ecology 15(6), 1044-1045.

OECD (2011), OECD Guidelines for Multinational Enterprises, 2011 Edition, OECD.

OECD (2018), 'OECD Due Diligence Guidance for Responsible Business Conduct'.

O’Rourke, D. (2003), 'Outsourcing Regulation: Analyzing Nongovernmental Systems of Labor Standards and Monitoring', Policy Studies Journal 31(1), 1-29.

Perneger, T. V. (1998), 'What's wrong with Bonferroni adjustments', British Medical Journal 316(7139), 1236-1238. 
Peters, G. P., Minx, J. C., Weber, C. L. \& Edenhofer, O. (2011), 'Growth in emission transfers via international trade from 1990 to 2008', Proceedings of the National Academy of Sciences 108(21), 8903-8908.

Pigou, A. C. (1920), The Economics of Welfare, Palgrave Classics in Economics, fourth edition 2013 edn, Palgrave Macmillan, Houndmills, Basingstoke, Hampshire ; New York.

Pope, S. \& Lim, A. (2019), 'The Governance Divide in Global Corporate Responsibility: The Global Structuration of Reporting and Certification Frameworks, 1998-2017', Organization Studies pp. 1-34.

Porter, M. E. \& Van Der Linde, C. (1995), 'Toward a New Conception of the EnvironmentCompetitiveness Relationship', The Journal of Economic Perspectives 9(4), 97-118.

Rexhäuser, S. \& Rammer, C. (2014), 'Environmental Innovations and Firm Profitability: Unmasking the Porter Hypothesis', Environmental and Resource Economics 57(1), 145167.

Ruggie, J. G. (2013), Just Business: Multinational Corporations and Human Rights, 1 edn, W. W. Norton \& Company, New York.

Ruggie, J. G. (2018), 'Multinationals as global institution: Power, authority and relative autonomy: Multinationals as global institution', Regulation \& Governance 12(3), 317333.

Scherrer, A. (2017), 'Unternehmensverantwortung? Ja, aber...' $\quad$ https://www.srf.ch/news/wirtschaft/internationale-konzerneunternehmensverantwortung-ja-aber.

Sen, S., Du, S. \& Bhattacharya, C. B. (2016), 'Corporate social responsibility: A consumer psychology perspective', Current Opinion in Psychology 10, 70-75. 
Serdült, U. (2014), Referendums in Switzerland, in M. Qvortrup, ed., 'Referendums Around the World: The Continued Growth of Direct Democracy', Palgrave Macmillan UK, London, pp. 65-121.

URL: https://doi.org/10.1057/9781137314703_4

Spiegel Online (2019), Wirtschaft wettert gegen Verpflichtung zu Menschenrechten, Online Bericht, Spiegel.

Steg, L. (2016), 'Values, Norms, and Intrinsic Motivation to Act Proenvironmentally', Annual Review of Environment and Resources 41(1), 277-292.

Stöhr, P. \& Michel, A. (2015), Corporate Social Responsibility aus Sicht der Unternehmen, Technical report, EconomieSuisse, SwissHoldings AG, Zürich.

Tosun, J., Koos, S. \& Shore, J. (2016), 'Co-governing common goods: Interaction patterns of private and public actors', Policy and Society 35(1), 1-12.

UNEP, ed. (2011), Decoupling Natural Resource Use and Environmental Impacts from Economic Growth. OCLC: 838605225.

United Nations (2011), 'Guiding Principles on Business and Human Rights'.

Urpelainen, J. (2011), 'Frontrunners and Laggards: The Strategy of Environmental Regulation under Uncertainty', Environmental and Resource Economics 50(3), 325-346.

Vogel, D. (2006), The Market for Virtue: The Potential and Limits of Corporate Social Responsibility, paperback edn, Brookings Inst. Press, Washington, DC. OCLC: 604843196.

Wackernagel, M., Onisto, L., Bello, P., Linares, C., Falfan, I. S. L., Garcia, J. M., Guer- 
rero, I. S. \& Guerrero, M. G. S. (1999), 'National natural capital accounting with the ecological footrpint concept', Ecological Economics 29, 375-390.

Wagner, M. (2003), The Porter Hypothesis Revisited, Literature Review, University Lüneburg, Lüneburg.

Walser, R. \& Bischofberger, A. (2013), Multis: Zerrbild und Wirklichkeit, Technical report, Avenir Suisse.

Werner, T. (2015), 'Gaining Access by Doing Good: The Effect of Sociopolitical Reputation on Firm Participation in Public Policy Making', Management Science 61(8), 19892011.

Weydt, E. \& Küstner, K. (2019), Deutsche Politik bremst UN-Standards aus, Online Bericht, Arbeitsgemeinschaft der öffentlich-rechtlichen Rundfunkanstalten der Bundesrepublik Deutschland (ARD).

Working Group on Responsible Business Conduct (2019), Shadow EU Action Plan on the Implementation of the UN Guiding Principles on Business and Human Rights within the EU, Action Plan, European Parliament, Brussels.

Zacharakis, Z. (2019), 'Für die Wirtschaft derart schädlich', Die Zeit .

Ziegler, A., Busch, T. \& Hoffmann, V. H. (2011), 'Disclosed corporate responses to climate change and stock performance: An international empirical analysis', Energy Economics 33(6), 1283-1294. 


\section{Online Appendix for 'VOLUNTARY BUSINESS INITIATIVES CAN REDUCE PUBLIC PRESSURE FOR REGULATING FIRM BEHAVIOUR ABROAD'}

\section{A.1 Demand for Regulation: The Case of the Responsible Busi- ness Initiative}

The following section introduces our case, the Responsible Business Initiative in Switzerland, by which civil society organizations and citizens in Switzerland seek to implement a strict and binding implementation of the "UN Guiding Principles on Business and Human Rights", and thus improve the environmental and human rights performance of Swiss companies in foreign countries.

The direct democratic political system in Switzerland gives citizens the right for a citizens' initiative for a partial revision of the Swiss Constitution (also called 'petition for a popular referendum', German: "Eidgenössischen Volksinitiative auf Teilrevision der Bundesverfassung"). This is a far-reaching mean for citizens to directly amend the Constitution from outside parliament, without judicial review. As discussed by Serdült 2014, 72f.), with such an initiative, "[p]arliament in such a case has no control over the proposed text, which can take the form of a general proposal or of a specific draft. In cases where parliament agrees with a general proposition, it is supposed to draft the respective constitutional provisions and submit it to a vote. In cases where it does not agree, the proposition is put to the people for a vote [...]. Should the people accept, a corresponding bill has to be drafted by the National Assembly, which is then again put forward to the people for a binding vote (requiring a double majority)." The only two requirements to start such an initiative is a collection of 100,000 signatures of Swiss citizens within 
18 months, and its formal correctness (compliance with ius cogens and comprising only one well-defined subject). Hence, citizens can propose far-reaching institutional changes as well as submit extreme policy, though these are rarely accepted at the ballot box in political practice. Note that parliament can react to initiatives in two ways: First, by coupling the initiative with a direct counter-proposal. As noted by Serdült $(2014,73)$, "counter-proposals are usually less extreme than citizens' initiatives; however, they tend to incorporate some of the demands by the initiators and thus have, in general, a higher chance of passing." If a direct counter-proposal is put on the ballot by the legislative, citizens vote yes/no for both initiative and counter-proposal and answer a tie-break question (which proposal should be accepted in case of a dual yes vote). Second, the legislative can agree on a so-called indirect counter-proposal. This is a law, which both parliamentary chambers agree upon. While this law is not put before the people, it takes up the core demands of an initiative in a less extreme form, intending to provide incentives to the initiators of the initiative to pull back their requests before the vote happens.

The following subsection lists the proposed initiative text, i.e. what citizens will vote on to ensure compliance of Switzerland with the UN Guiding Principles on Business and Human Rights. Next, we present the broader context of the initiative, details on the institutional setting, and its timeline, and place our survey therein.

\section{A.1.1 Responsible Business Initiative: English translation of the proposed amendment to the constitution by the initiative}

The Federal Constitution will be amended as follows:

Art 101a: Responsibility of business

1 The Confederation shall take measures to strengthen respect for human rights and the environment through business. 
2 The law shall regulate the obligations of companies that have their registered office, central administration, or principal place of business in Switzerland according to the following principles:

a. Companies must respect internationally recognised human rights and international environmental standards, also abroad; they must ensure that human rights and environmental standards are also respected by companies under their control. Whether a company controls another is to be determined according to the factual circumstances. Control may also result through the exercise of power in a business relationship.

b. Companies are required to carry out appropriate due diligence. This means in particular that they must: identify real and potential impacts on internationally recognised human rights and the environment; take appropriate measures to prevent the violation of internationally recognised human rights and international environmental standards, cease existing violations, and account for the actions taken. These duties apply to controlled companies as well as to all business relationships. The scope of the due diligence to be carried out depends on the risks to the environment and human rights. In the process of regulating mandatory due diligence, the legislator is to take into account the needs of small and medium-sized companies that have limited risks of this kind.

c. Companies are also liable for damage caused by companies under their control where they have, in the course of business,committed violations of internationally recognised human rights or international environmental standards. They are not liable under this provision however if they can prove that they took all due care per paragraph b to avoid the loss or damage, or that the damage would have occurred even if all due care had been taken.

d. The provisions based on the principles of paragraphs a $-\mathrm{c}$ apply irrespective of the 
law applicable under private international law.

\section{A.1.2 Responsible Business Initiative: Context and Timeline}

In the last (almost) decade, an international debate highlighted regulatory gaps between countries and emphasised countries' duty and corporations' responsibility to guarantee social and environmental minimum standards in production. The debate has been initiated by the United Nations' release of the 'UN Guiding Principles on Business and Human Rights' in 2011 (United Nations 2011). The paradigm posited in that document consists of three main elements:

1. states' duty to protect their citizens from threats (also from corporations),

2. corporate responsibility to respect human rights, and

3. individuals' right to compensation for human rights violations by corporations.

Notably, the Guiding Principles promote a state duty to protect citizens from environmental damages and human rights violations ABROAD. This would require countries (in particular affluent Western countries), to regulate the behaviour of domestic firms and production conditions within those firms' supply chains on other countries' territory (hence, extraterritorial regulation). Even though this agenda is being promoted by international organisations (see also, UNEP 2011, OECD 2018), individual states are called upon to influence the extraterritorial behaviour of their companies.

To this day, the United Kingdom ('Modern Slavery Act', 2015) and France ('Duty of Vigilance Law', 2017) have enacted extraterritorial legislation on these issues. Both these laws require companies meeting particular criteria (e.g. concerning company size and turnover) to report on labour conditions (UK) and potential environmental and social risks in their supply chains (FR). In 2021, the European Union will enact the Conflict 
Minerals Regulation, which requires EU companies active in the minerals sector to ensure they import particular minerals and metals from responsible and conflict-free sources only. However, the regulation proposed in Switzerland goes far beyond the regulations implemented in the UK, France and the EU, since it would cover both environmental and social risks, since it would not be restricted to a particular economic sector and finally, since it would apply to a larger share of companies with supply chains extending beyond Swiss borders (i.e. particular small and medium-sized firms as well).

As outlined above, the direct democratic institutional framework, in which this regulation (known as RBI) is proposed, is the so-called 'petition for a popular referendum' (German: Volksinitiative). By collecting 100,000 signatures within 18 months, Swiss citizens (and organisations) are permitted to initiate popular referenda on constitutional amendments. Hence, these referenda have the potential to create far-reaching competencies for government intervention - in the case of the RBI, in companies' business conduct. This particular petition has been submitted by an alliance of humanitarian and environmental civil society organisations in 2016. Their demands are outlined in Appendix Section A.1.1. However, since its submission the RBI has been stuck in Parliament without being voted upon to this day (for Swiss direct democratic institutions see Serdült 2014).

The reason is that the Swiss Parliament has decided to draft a so-called 'indirect counter-proposal' (see above). The policy-making process, thus, has turned into a strategic game between the petitioners and the different chambers and committees inside the Swiss Parliament (see, e.g. Hofer et al. 2017). In the case of the RBI, both chambers of the Swiss Parliament opted to write a counter-proposal in November of 2017. However, they were unable to agree on the content of the counter-proposal to this day - with left and green parties supporting more stringent regulation, liberal and right-wing parties op- 
posing it (see a timeline of negotiations below). Hence, as of now, a popular referendum on the RBI is still the most likely outcome.

- April 21, 2015: Responsible Business Initiative registered and starting to collect signatures

- October 10, 2016: Responsible Business Initiative submitted to federal chancellery with 120 '418 signatures

- November 2017: Ständerat (upper chamber) committee opts to write an indirect counter-proposal

- December 2017: Nationalrat (lower chamber) committee decides against indirect counter-proposal

- February 2018: Nationalrat (lower chamber) committee reconsidering its decision, opts to write an indirect counter-proposal

- June 2018: Nationalrat (lower chamber) accepts indirect counter-proposal

- October 2018: Ständerat (upper chamber) committee decides to use sub-committee

- March 2019: Sub-committee result

- March 2019: Ständerat (upper chamber) rejects indirect counter-proposal

- March 2019: Nationalrat (lower chamber) committee maintains indirect counterproposal

- June 2019: Nationalrat (lower chamber) decides to maintain indirect counterproposal again 
- December 2019: Ständerat (upper chamber) rejects indirect counter-proposal, agrees to have one final round of negotiations with Nationalrat (lower chamber).

- March 2020: Final round of negotiations between both chambers in Parliament: Decision on existence and content of indirect counter-proposal must be reached.

- November 2020: Latest possible date for a popular referendum

\section{A.2 Survey Instrument and Research Design}

\section{A.2.1 Wording of the Experimental Vignettes (English Translation)}

The following text was used to introduce respondents to the vignette task. Below the introductory paragraph, we list all the treatments (our translations from the German originals). The treatment 'titles' (not shown to respondents) are printed in bold letters.

"Swiss companies operating abroad sometimes cause damage to people and the environment. The risk of such damage can vary greatly from company to company. For example, it is often higher for Swiss companies that deal with raw materials (e.g. gold, copper, oil and gas, coffee, cotton). Such risks can be reduced by voluntary measures taken by the Swiss companies themselves or by government-set rules.

[screen-break]

Placebo text: The question of how risks should be reduced is a recurring topic of discussion in politics and society. In particular, there are different opinions on how Swiss companies should behave at home and abroad and whether rules should be established for companies. 
Few firms, with high-risk firms, with NGO oversight: The Swiss private sector is already dealing with the issue. However, only a few Swiss companies have voluntarily committed themselves to protect people and the environment at their operating sites abroad to a much greater degree. Specifically, they have promised to issue a comprehensive yearly report on risks to people and the environment and according measures to reduce such risks. This report will be checked by an independent, not-for-profit organisation. The full report and the result of the verification will be published on the internet. Among the participating companies are most Swiss companies involved in commodities (such as gold, copper, oil and gas, coffee, cotton).

Many firms, no high-risk firms, without NGO mention: The Swiss private sector is already dealing with the issue. Most Swiss companies have voluntarily committed themselves to protect people and the environment at their operating sites abroad to a much greater degree. Specifically, they have promised to issue a comprehensive yearly report on risks to people and the environment and according measures to reduce such risks. The full report will be published on the internet.

Many firms, no high-risk firms, with NGO oversight: The Swiss private sector is already dealing with the issue. Most Swiss companies have voluntarily committed themselves to protect people and the environment at their operating sites abroad to a much greater degree. Specifically, they have promised to issue a comprehensive yearly report on risks to people and the environment and according measures to reduce such risks. This report will be checked by an independent, not-for-profit organisation. The full report and 
the result of the verification will be published on the internet.

Many firms, with high-risk firms, without NGO mention: The Swiss private sector is already dealing with the issue. Most Swiss companies have voluntarily committed themselves to protect people and the environment at their operating sites abroad to a much greater degree. Specifically, they have promised to issue a comprehensive yearly report on risks to people and the environment and according measures to reduce such risks. The full report will be published on the internet. Among the participating companies are most Swiss companies involved in commodities (such as gold, copper, oil and gas, coffee, cotton).

Many firms, with high-risk firms, with NGO: The Swiss private sector is already dealing with the issue. Most Swiss companies have voluntarily committed themselves to protect people and the environment at their operating sites abroad to a much greater degree. Specifically, they have promised to issue a comprehensive yearly report on risks to people and the environment and according measures to reduce such risks. This report will be checked by an independent, not-for-profit organisation. The full report and the result of the verification will be published on the internet. Among the participating companies are most Swiss companies involved in commodities (such as gold, copper, oil and gas, coffee, cotton)."

\section{A.2.2 Sample and Survey Structure}

On the introductory page of the survey, participants were informed about the purpose of the survey and guaranteed anonymity. At the end of the survey, the participants were 
provided with a debriefing statement, which read that certain information had to be strongly simplified for scientific purposes. Furthermore, the debriefing included a link to the Swiss administration's website, where official information about the survey's content with 'real world' political implications was available.

In the survey, participants first responded to questions relevant to the sampling strategy. They were then confronted with two experiments (experiment A and experiment B) in a randomised order. From now on, the experiment generating the data for this paper will be referred to as experiment B. Despite being related in terms of content (international environmental and human rights standards and regulation for Switzerlandbased MNEs), the two experiments differed on dependent and independent variables and on the tasks, participants were asked to perform - a vignette and a conjoint in experiment A, only a vignette in experiment B. All respondents were required to complete both experiments, however, we evenly randomised the order of the two experiments in order to control for unwanted carryover effects from the first experiment to the second. If participants were confronted with experiment A first before entering experiment B, these questions might have contaminated the responses to the experiment. We chose not to ask questions between the experiments since asking participants about their preferences between the experiments might have had different effects on the two. This, in turn, would have jeopardised the control introduced by the randomised order of the experiments. After having completed both experiments, the participants concluded the survey by responding to questions about environmental and political attitudes and a standard set of socio-demographic questions.

Appendix Table A.1 summarises the distribution of responses to a question measuring respondents' perceived ability to explain the content of the RBI to someone else. Given random assignment to either experiment $A$ first or experiment $B$ first, we would expect 
an even distribution of responses in Appendix Table A.1. This, however, is not the case - the chi-squared test strongly suggests that order assignment and responses are not independent. In particular, the table shows that individuals, who were confronted with experiment A first, deem themselves (at least 'maybe') more able to explain the content of the RBI to someone else. This indicates that the questions embedded in experiment A are likely to have had a content-related carryover effect on respondents' perceived level of information about the issue.

Therefore, we were forced to distinguish between a 'pure' and a 'full' sample in our data analysis, as exemplified by Appendix Table A.2. The pure sample was used for the data analysis reported in the main paper. It refers to the group of participants who responded to experiment B right at the beginning of the survey - the experiment B first group - where carryover effects are not an issue by design. Hence, these responses yield the most accurate estimates of our treatment effects. Accordingly, the full sample pools all respondents regardless of the order in which they were administered the survey components. The experiment A first group will from now on, be referred to as the 'contaminated' sample.

The carryover effect is documented in greater detail in the following: Appendix Tables A.3 and A.2 contain estimated effects of the pooled treatments compared to the placebo group. Specifically, A.2 shows the coefficient estimates for the pure sample in the left panel and the full sample in the right panel. We observe that across all dependent variables that the estimated pooled treatment effect is less substantive in the full sample. The reason is that the full sample pools both the pure sample and the contaminated one. Appendix Table A.3 summarises the coefficient estimates for the contaminated sample, where we find that the effect of the pooled treatment is not significantly different from 0 on any dependent variables. Overall, it seems to be the case that by exposing respondents to information related to adverse social and environmental impacts of Swiss MNEs abroad 
and potential regulatory instruments to curb these impacts, experiment A has primed respondents towards regulation - particularly towards the RBI - and made them 'immune' to the treatments in experiment B related to voluntary measures by the private sector.

We can rule out that the differences between the pure and the contaminated sample have been primarily caused by a drop in the attentiveness of the participants. Excluding respondents based on the screening time of the treatments in experiment B does little in terms of correcting for the difference in results between the pure sample and the contaminated sample (see Appendix Table A.4.

In the following Sections of the Appendix, tables show results for the pure sample on the left panel (corresponding to the results reported in the main paper) and the full sample on the right panel. The coefficients always represent the estimates for the effects of the treatment relative to the placebo group.

Table A.1: Would you deem yourself able to explain the content of the RBI to someone else?

\begin{tabular}{|l|l|l|}
\hline & Exp. A first & Exp. B first \\
\hline Maybe & 582 & 496 \\
\hline No & 506 & 875 \\
\hline Yes & 358 & 193 \\
\hline
\end{tabular}

Chi-squared: $13.3, \mathrm{p}<0.01$. 
Table A.2: Pooled treatment effects

\begin{tabular}{|c|c|c|c|c|c|c|c|c|c|c|c|c|}
\hline & \multicolumn{6}{|c|}{ Pure sample } & \multicolumn{6}{|c|}{$\begin{array}{|cc|} & \text { Full sample }\end{array}$} \\
\hline & $\begin{array}{l}(1) \\
\text { Regulation pref. }\end{array}$ & $\begin{array}{l}(2) \\
\text { VM sufficient }\end{array}$ & $\begin{array}{c}(3) \\
\text { RBI rating }\end{array}$ & $\begin{array}{c}(4) \\
\text { RBI yes share }\end{array}$ & $\begin{array}{c}(5) \\
\text { RBI no share }\end{array}$ & $\stackrel{(6)}{\text { RBI undecided share }}$ & $\begin{array}{c}(7) \\
\text { Regulation pref. }\end{array}$ & $\begin{array}{c}(8) \\
\text { VM sufficient }\end{array}$ & $\begin{array}{c}(9) \\
\text { RBI rating }\end{array}$ & $\begin{array}{l}(10) \\
\text { RBI yes share }\end{array}$ & $\begin{array}{l}(11) \\
\text { RBI no share }\end{array}$ & $\begin{array}{c}(12) \\
\text { RBI undecided share }\end{array}$ \\
\hline Any voluntary corporate program $=1$ & $\begin{array}{l}-0.13^{+} \\
(0.08)\end{array}$ & $\begin{array}{l}0.17^{*} \\
(0.07)\end{array}$ & $\begin{array}{l}-0.22^{*} \\
(0.10)\end{array}$ & $\begin{array}{c}-0.06^{+} \\
(0.03)\end{array}$ & $\begin{array}{l}0.06^{*} \\
(0.03)\end{array}$ & $\begin{array}{c}0.00 \\
(0.03)\end{array}$ & $\begin{array}{l}-0.12^{*} \\
(0.05)\end{array}$ & $\begin{array}{l}0.16^{* *} \\
(0.05)\end{array}$ & $\begin{array}{l}-0.16^{*} \\
(0.07)\end{array}$ & $\begin{array}{c}-0.05^{+} \\
(0.02)\end{array}$ & $\begin{array}{l}0.04^{*} \\
(0.02)\end{array}$ & $\begin{array}{l}0.01 \\
(0.02)\end{array}$ \\
\hline Constant & $\begin{array}{c}5.11^{* * *} \\
(0.64)\end{array}$ & $\begin{array}{l}1.56^{* *} \\
(0.59)\end{array}$ & $\begin{array}{c}5.73^{* * *} \\
(0.87)\end{array}$ & $\begin{array}{l}1.07^{* * *} \\
(0.28)\end{array}$ & $\begin{array}{l}-0.18 \\
(0.23)\end{array}$ & $\begin{array}{c}0.11 \\
(0.24)\end{array}$ & $\begin{array}{l}4.55^{* * *} \\
(0.58)\end{array}$ & $\begin{array}{c}2.08^{* * *} \\
(0.55)\end{array}$ & $\begin{array}{c}5.04^{* * *} \\
(0.79)\end{array}$ & $\begin{array}{c}1.03^{* * *} \\
(0.26)\end{array}$ & $\begin{array}{l}-0.10 \\
(0.21)\end{array}$ & $\begin{array}{c}0.07 \\
(0.22)\end{array}$ \\
\hline Controls & Yes & Yes & Yes & Yes & Yes & Yes & Yes & Yes & Yes & Yes & Yes & Yes \\
\hline $\mathrm{N}$ & 1458.00 & 1422.00 & 1473.00 & 1474.00 & 1474.00 & 1474.00 & 2781.00 & 2714.00 & 2816.00 & 2818.00 & 2818.00 & 2818.00 \\
\hline r2_a & 0.14 & 0.14 & 0.16 & 0.09 & 0.09 & 0.02 & 0.15 & 0.15 & 0.17 & 0.10 & 0.10 & 0.03 \\
\hline Control_mean & 3.73 & 2.43 & 4.98 & 0.64 & 0.16 & 0.20 & 3.76 & 2.47 & 4.97 & 0.63 & 0.16 & 0.21 \\
\hline Control_sd & 1.14 & 1.00 & 1.57 & 0.48 & 0.37 & 0.40 & 1.11 & 1.04 & 1.53 & 0.48 & 0.37 & 0.41 \\
\hline
\end{tabular}


Table A.3: Pooled treatment effect in the contaminated sample

\begin{tabular}{|c|c|c|c|c|c|c|}
\hline & \multicolumn{6}{|c|}{ Dependent variable: } \\
\hline & $\begin{array}{l}\text { Regulation pref. } \\
\text { (1) }\end{array}$ & $\begin{array}{c}\text { VM sufficient } \\
(2) \\
\end{array}$ & $\begin{array}{c}\text { RBI rating } \\
(3) \\
\end{array}$ & $\begin{array}{c}\text { RBI yes share } \\
(4)\end{array}$ & $\begin{array}{c}\text { RBI no share } \\
(5)\end{array}$ & $\begin{array}{c}\text { RBI undecided share } \\
(6)\end{array}$ \\
\hline Any voluntary corporate program $=1$ & $\begin{array}{c}-0.123 \\
(0.076)\end{array}$ & $\begin{array}{c}0.120 \\
(0.074)\end{array}$ & $\begin{array}{c}-0.064 \\
(0.103)\end{array}$ & $\begin{array}{l}-0.022 \\
(0.034)\end{array}$ & $\begin{array}{c}0.006 \\
(0.027)\end{array}$ & $\begin{array}{c}0.016 \\
(0.029)\end{array}$ \\
\hline Observations & 1,318 & 1,289 & 1,338 & 1,339 & 1,339 & 1,339 \\
\hline Adjusted $\mathrm{R}^{2}$ & 0.152 & 0.162 & 0.162 & 0.102 & 0.108 & 0.050 \\
\hline Residual Std. Error & $1.010(\mathrm{df}=1276)$ & $0.986(\mathrm{df}=1247)$ & $1.389(\mathrm{df}=1296)$ & $0.459(\mathrm{df}=1297)$ & $0.358(\mathrm{df}=1297)$ & $0.391(\mathrm{df}=1297)$ \\
\hline
\end{tabular}

Table A.4: Pooled treatment effect in the contaminated sample controlling for screening time

\begin{tabular}{|c|c|c|c|c|c|c|}
\hline & \multicolumn{6}{|c|}{ Dependent variable: } \\
\hline & $\begin{array}{l}\text { Regulation pref. } \\
\text { (1) }\end{array}$ & $\begin{array}{c}\text { VM sufficient } \\
(2)\end{array}$ & $\begin{array}{c}\text { RBI rating } \\
\text { (3) }\end{array}$ & $\begin{array}{c}\text { RBI yes share } \\
(4)\end{array}$ & $\begin{array}{c}\text { RBI no share } \\
(5)\end{array}$ & $\begin{array}{c}\text { RBI undecided share } \\
(6)\end{array}$ \\
\hline Any voluntary corporate program $=1$ & $\begin{array}{c}-0.152^{*} \\
(0.086)\end{array}$ & $\begin{array}{c}0.105 \\
(0.082)\end{array}$ & $\begin{array}{c}-0.054 \\
(0.119)\end{array}$ & $\begin{array}{l}-0.046 \\
(0.038)\end{array}$ & $\begin{array}{c}0.006 \\
(0.030)\end{array}$ & $\begin{array}{c}0.040 \\
(0.032)\end{array}$ \\
\hline $\begin{array}{l}\text { Observations } \\
\text { Adjusted } \mathrm{R}^{2} \\
\text { Residual Std. Error }\end{array}$ & $\begin{array}{c}1,092 \\
0.142 \\
1.009(\mathrm{df}=1050)\end{array}$ & $\begin{array}{c}1,065 \\
0.169 \\
0.954(\mathrm{df}=1023)\end{array}$ & $\begin{array}{c}1,101 \\
0.150 \\
1.411(\mathrm{df}=1059)\end{array}$ & $\begin{array}{c}1,101 \\
0.091 \\
0.454(\mathrm{df}=1059)\end{array}$ & $\begin{array}{c}1,101 \\
0.109 \\
0.353(\mathrm{df}=1059)\end{array}$ & $\begin{array}{c}1,101 \\
0.036 \\
0.376(\mathrm{df}=1059)\end{array}$ \\
\hline
\end{tabular}

Linear regression of a pooled treatment group indicator on indicators of support for regulation (see model header) in the contaminated sample, i.e. the sample which did see another experiment beforehand. Individuals $40 \%$ below the median experiment B treatment screening time in the sample have been excluded. Standard errors displayed in parentheses. Control variables are used where indicated (gender, age group, self-evaluation of personal economic situation, education level, employment status, rurality, language, parentheses. Control variables are used where indicated (gender, age group, self-evaluation of personal econol
region of Switzerland, self-placement on left-right scale, party ID, and self-stated usual voting frequency))

* $\left(.{ }^{* *},{ }^{* * *}\right)$ indicates $\mathrm{p}<0.05(0.1,0.01,0.001)$

\section{A.2.3 Properties of the Sampled Population}

As we draw on a quota sample, our survey is representative for the general population of Switzerland only with respect to the interlocked quotas on age and gender as well as quotas on education and regional provenance of the participants. However, as can be seen from Figure A.1, when comparing the distribution of a core non-quota characteristic (environmental concern) from our surveyed population to the distribution of the same variable in a dual-mode representative survey fielded as well in 2018 (Swiss Environmental Panel, first wave), we observe a highly comparable distribution. 


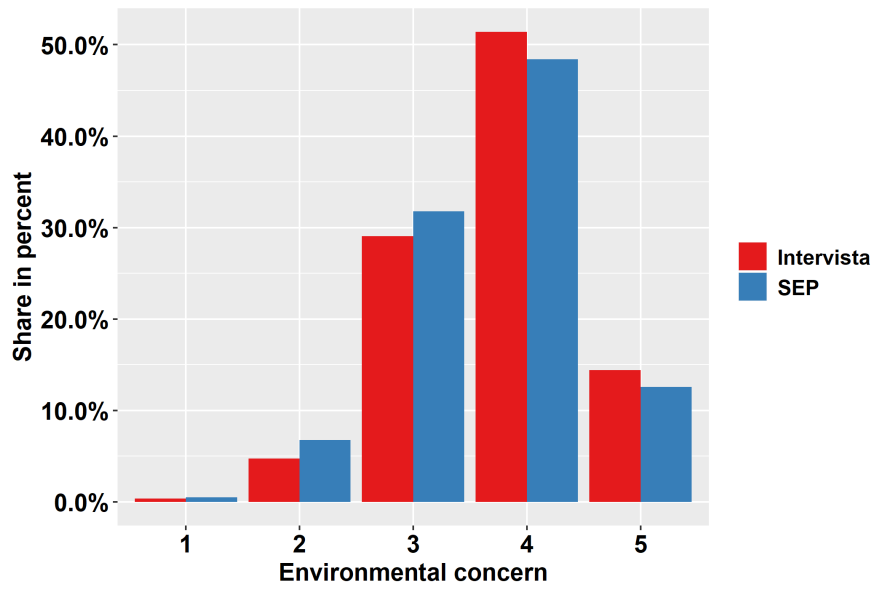

Figure A.1: The blue bars $(\mathrm{N}=4813)$ show the distribution of the environmental concern scale (Diekmann \& Preisendörfer 2003) as measured in the first wave of the Swiss Environmental Panel (SEP), a 2018 dual-mode survey based on a random sample of the Swiss population drawn by the Federal Statistical Office (FSO). In comparison, the red bars $(\mathrm{N}=3010)$, indicate the distribution of environmental concern among participants in our quota sample drawn from Intervista's online panel. A global test of the equality of distribution functions (Kaplan 2019) shows that both functions likely do not differ statistically (p-value 0.708). 


\section{A.3 Subgroup Analyses}

The following Appendix Section presents subgroup analyses for the item "RBI support" (item wording: 'If you were to vote today on the Responsible Business Initiative, how would you vote? I would accept it/reject it/don't know.'). We report subgroup effects for several relevant characteristics and attitudes we enquired from respondents, from the political, economic and social realm as well as for demographics. These variables present a standard set of potential political, social, economic and demographic mediators of the treatment effect. As we did not pre-register any hypothesised relationships between these covariates and our treatment effects, we refrain from strong interpretations. Additionally, as we did not experimentally manipulate the mediating variables, we only observe correlational evidence. Still, these patterns are informative for future research, as it allows to develop hypotheses on which particular voters are moved by voluntary corporate programs and why this might be the case.

We report subgroup effects by several socio-political covariates:

- Voting probability (high: self-reported usual participation in 4 out of 4 annual election days; low: 0-3), Appendix Table A.5 and Appendix Figure A.2.

- Self-reported high-probability voters respond much more strongly to the corporate behaviour vignettes, differences are significant on the $0.1 \%$-level for the many/few, risk, NGO and on the 10\%-level for the many, $N G O$-vignette. These respondents also show a higher baseline support level for the RBI.

- Political interest (high: scores 4, 5; low: scores 1-3 on a 5-point Likert scale), Appendix Figure A.3.

- High or low self-reported political interest does not differentiate reactions to vignettes. 
- Prior knowledge of RBI initiative ("Have you ever heard of this initiative or read anything about it? [Yes; No; Don't know]"), Appendix Table A.6 and Appendix Table A.4

- Starting from a comparable baseline support level, the subgroup of individuals with prior exposure to the RBI (25\% of respondents report "having heard" of the RBI, see Appendix Table A.4) reacts very similarly to the experimental vignettes. There is one notable exception, though: While the many-vignette decreases demand for regulation among those unfamiliar with the RBI, it increases this demand (significant at the 10\%-level; difference between groups significant at the 1\%-level) for the heaving-heard-group. This raises the question, why prior exposure might lead to differing responses. As knowledge was not experimentally assigned, one potential reason are differing background characteristics of respondents. Whether relatively weak experimental vignettes can also be perceived as shallow, given more knowledge is an interesting additional question for future research. While we tested for these mechanisms ourselves (see Appendix Table A.10), our tests do not have enough power to meaningfully differentiate responses (although, e.g. the vignettes not including high-risk firms and NGO oversight see slightly higher evaluations of being "window-dressing"). We hence recommend future research in this direction, at best exploiting experimental variation in knowledge of the issue.

- Environmental concern (High/low: Above/below median score), 8 Appendix Figure A.5.)

- Respondents with high environmental concern respond more strongly to the

$8 \quad$ Environmental concern is an additive index from a scale developed by Diekmann \& Preisendörfer (2003). 
corporate behaviour vignettes, although only the reaction to the few, risk, $N G O$-vignette is significantly different on the 10\%-level. Baseline support levels are much higher in the respondent subgroup with high environmental concern.

- Political ideology (Left: self-reported score of 0-5; Right: of 6-10 on an 11-point Likert scale), Appendix Figure A.6.

- Political ideology does not differentiate reactions significantly, although in tendency left-leaning respondents seem to be more in support for vignettes including NGO oversight, while right-leaning respondents react particularly strong to the many, risk, NGO -vignette. Baseline support for the RBI is higher among left-leaning respondents.

We as well report subgroup effects by several relevant demographic, economic, social and cultural characteristics of respondents, namely:

- Age (above/below median age), Appendix Figure A.7.

- Differentiating respondents by above/below median age does not meaningfully differentiate respondents. Note that additional analyses (available on request) revealed that in tendency the very young (below 30) and very old (above 60) age group reacted more strongly to the treatments.

- Gender (binary indicator variable, 1: female; 0: male), Appendix Figure A.8.

- Females react more strongly to most of the presented vignettes, although this difference is significant on the 5\%-level only for the many, $N G O$-vignette. Females also show stronger baseline support for the RBI. 
- Education (1: Higher education, i.e. university; 0: else), Appendix Figure A.9

- Respondents with lower education react more strongly to most of the presented vignettes, although this difference is significant on the $10 \%$-level only for the few, risk, NGO-vignette.

- Income (Above/below median income (9000 CHF)), Appendix Figure A.10.

- Respondents with lower income react more strongly to the presented vignettes, this difference is significant on the 5\%-level for the few, risk, NGO-and the many, risk-vignette, and significant on the 10\%-level for the many-vignette. These respondents also show stronger baseline support for the RBI.

- Employment ((Self-)employed vs. rest), Appendix Figure A.11.

- Respondents who are not (self-)employed react more strongly to the presented vignettes, although this difference is significant on the 10\%-level only for the many, $N G O$-vignette. These respondents also show stronger baseline support for the RBI.

- Language/culture (German speaking vs. Italian/French speaking, Appendix Figure A.12.

- Language/culture does not meaningfully differentiate respondents.

- Settlement type (Respondent from urban settlement vs. rural/agglomeration), Appendix Figure A.13.

- Respondents who are from rural areas/agglomeration react more strongly to the presented vignettes, although this difference is significant on the $5 \%$-level only for the many, risk-vignette. 
Finally, we differentiate the sample by attentiveness to the survey:

- Time to read treatment/placebo screen text on voluntary measures (above/below median time), Appendix Figure A.14

- Respondents below the median react more strongly to the presented vignettes, although this difference is significant on the 10\%-level only for the many, risk, $N G O$-vignette. 
Table A.5: How voluntary firm behaviour affects public support for the RBI for different levels of political participation

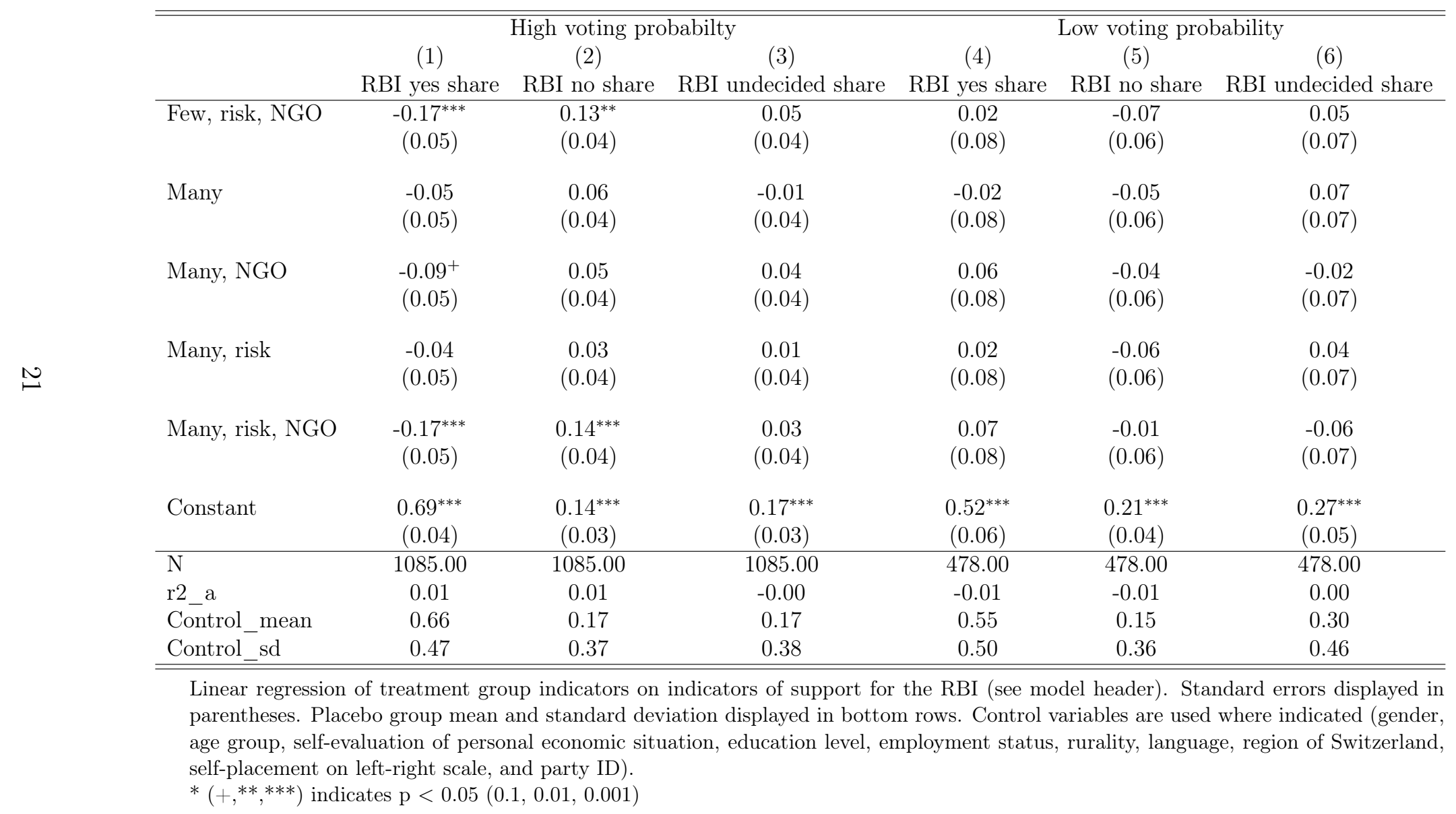




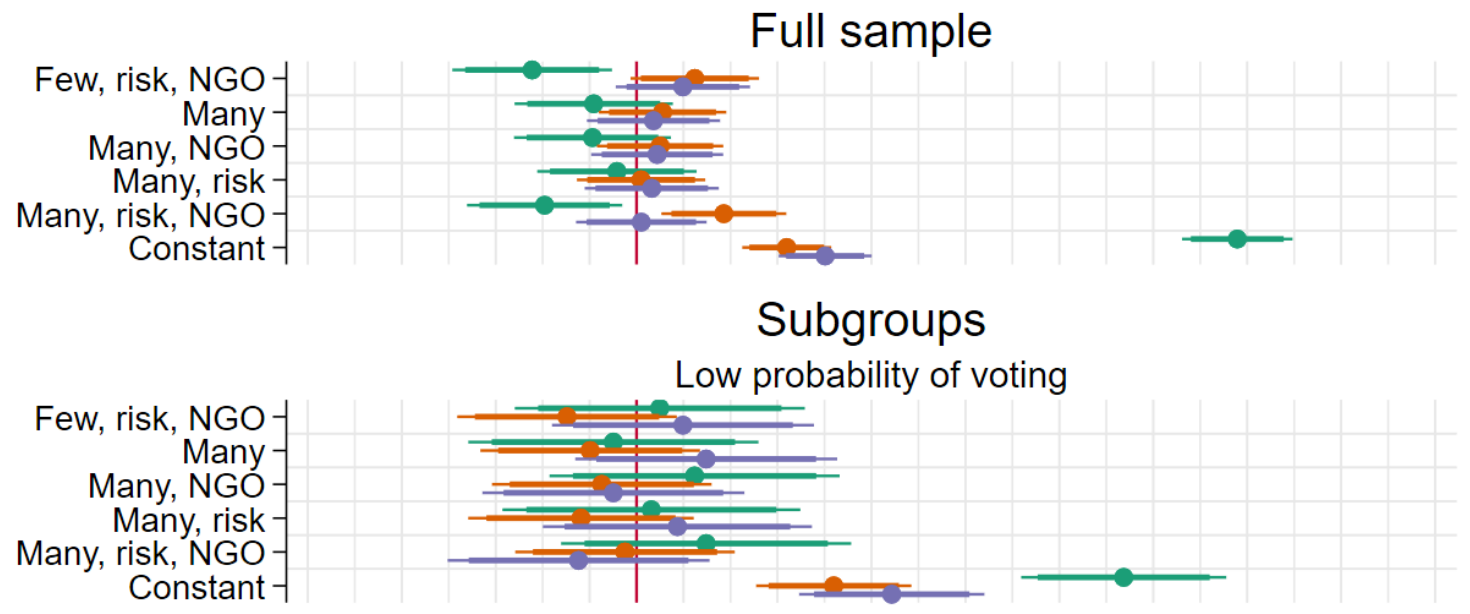

High probability of voting

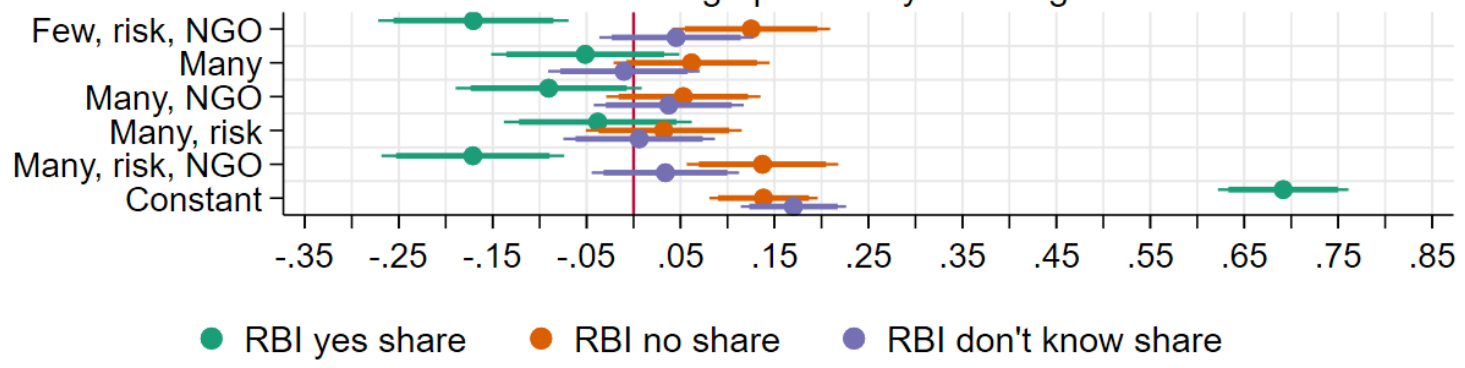

Figure A.2: Full sample and subgroup-analysis (subgroup indicated in header, as defined in the beginning of Appendix Section A.3, for treatment effect estimates of vignette conditions relative to the placebo group on outcome variable 'RBI support'. Constant shows baseline levels of yes/no/don't know shares. Whiskers report $95 \%$ and $90 \%$ confidence intervals. 


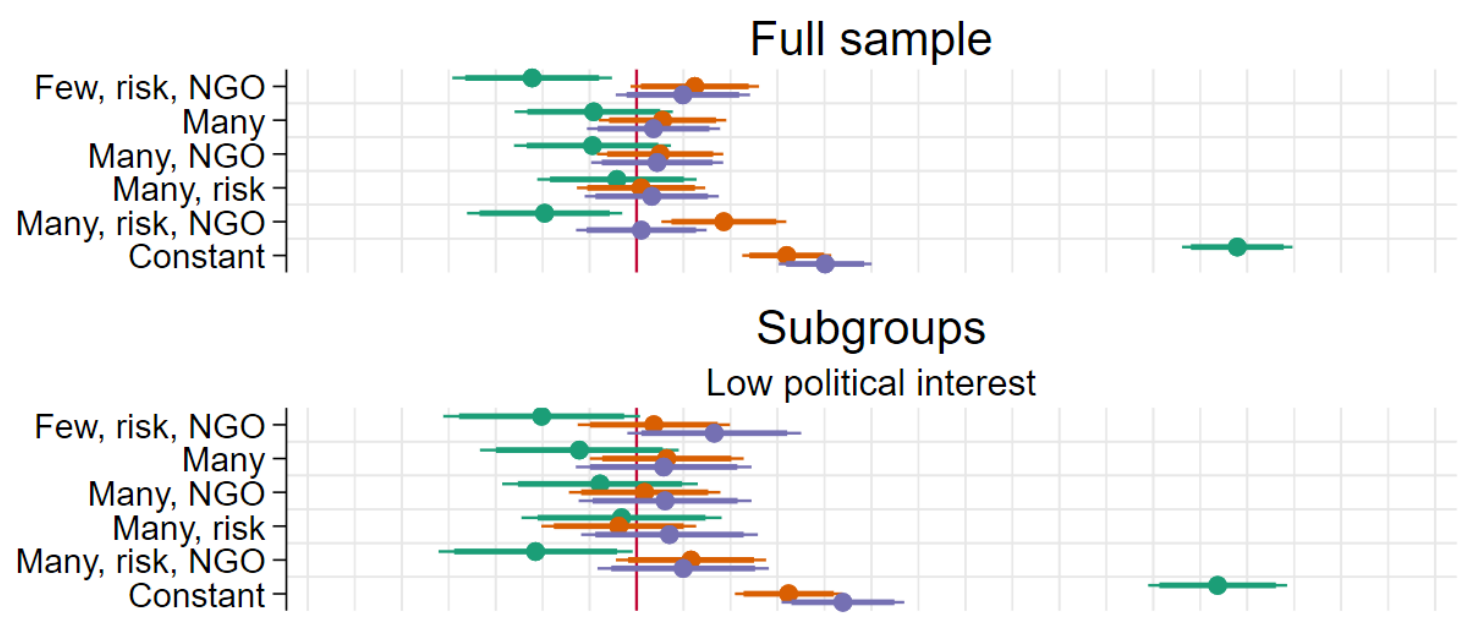

High political interest

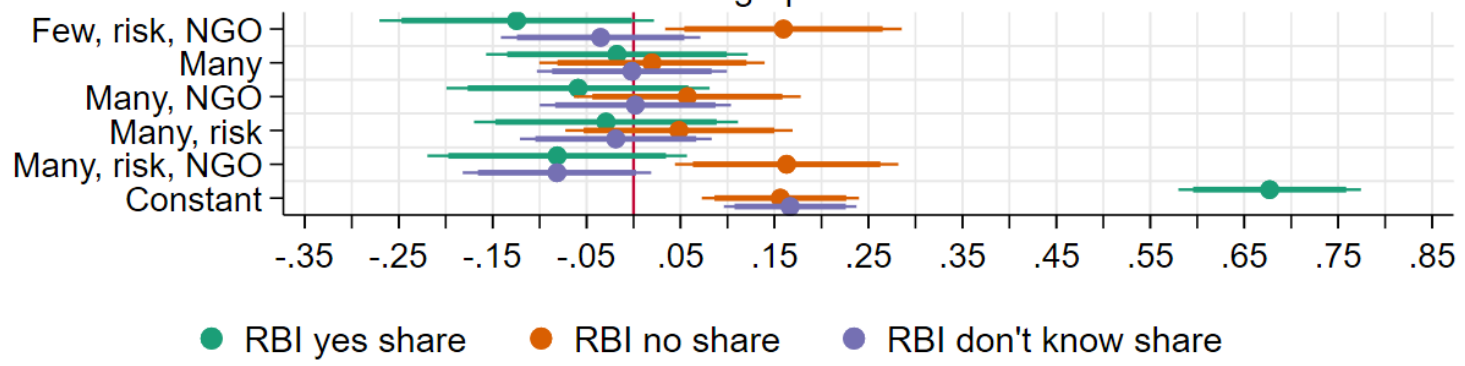

Figure A.3: Full sample and subgroup-analysis (subgroup indicated in header, as defined in the beginning of Appendix Section A.3, for treatment effect estimates of vignette conditions relative to the placebo group on outcome variable 'RBI support'. Constant shows baseline levels of yes/no/don't know shares. Whiskers report $95 \%$ and $90 \%$ confidence intervals. 
Table A.6: Knowledge on the Responsible Business Initiative

\begin{tabular}{lccc|ccc}
\hline \hline & \multicolumn{3}{c}{ Have heard of RBI? } & \multicolumn{3}{c}{ Can explain RBI? } \\
& freq & pct & cumpct & freq & pct & cumpct \\
\hline Yes & 384 & 24.55 & 24.55 & 104 & 27.08 & 27.08 \\
No & 1115 & 71.29 & 95.84 & 94 & 24.48 & 51.56 \\
Don't know & 65 & 4.16 & 100.00 & 186 & 48.44 & 100.00 \\
\hline Total & 1564 & 100.00 & & 384 & 100.00 & \\
\hline \hline
\end{tabular}

Raw distribution for questions 1) "Swiss citizens are expected to vote on the popular initiative 'for responsible companies' (Responsible Business Initiative) in the next 12 months. Have you ever heard of this initiative or read anything about it? [Yes; No; Don't know] and 2) "Would you be able to describe to another person what this initiative is about?" [Yes; No; Don't know] for respondents who report having heard/read about the RBI. 


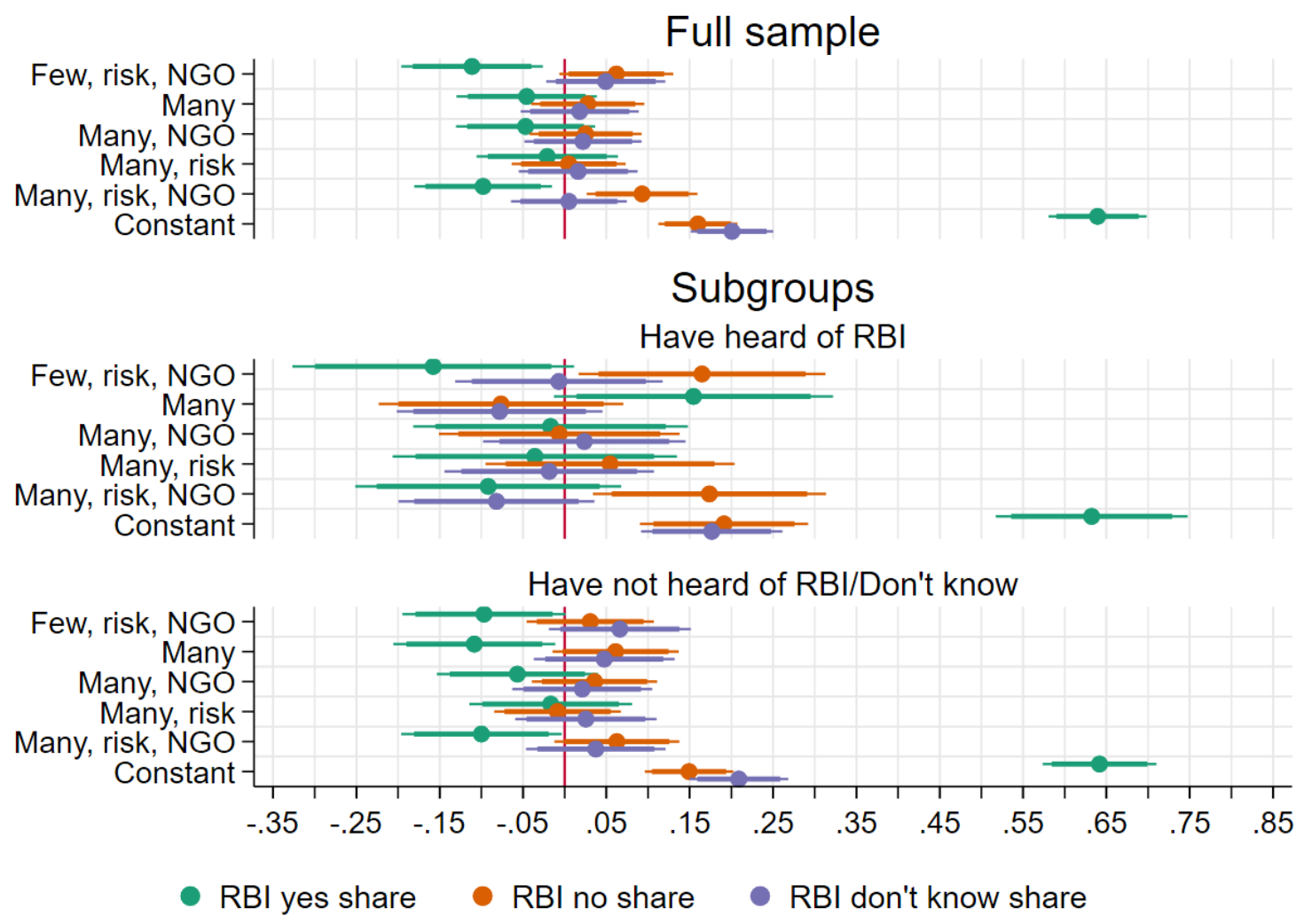

Figure A.4: Full sample and subgroup-analysis (subgroup indicated in header, as defined in the beginning of Appendix Section A.3, for treatment effect estimates of vignette conditions relative to the placebo group on outcome variable 'RBI support'. Constant shows baseline levels of yes/no/don't know shares. Whiskers report $95 \%$ and $90 \%$ confidence intervals. 

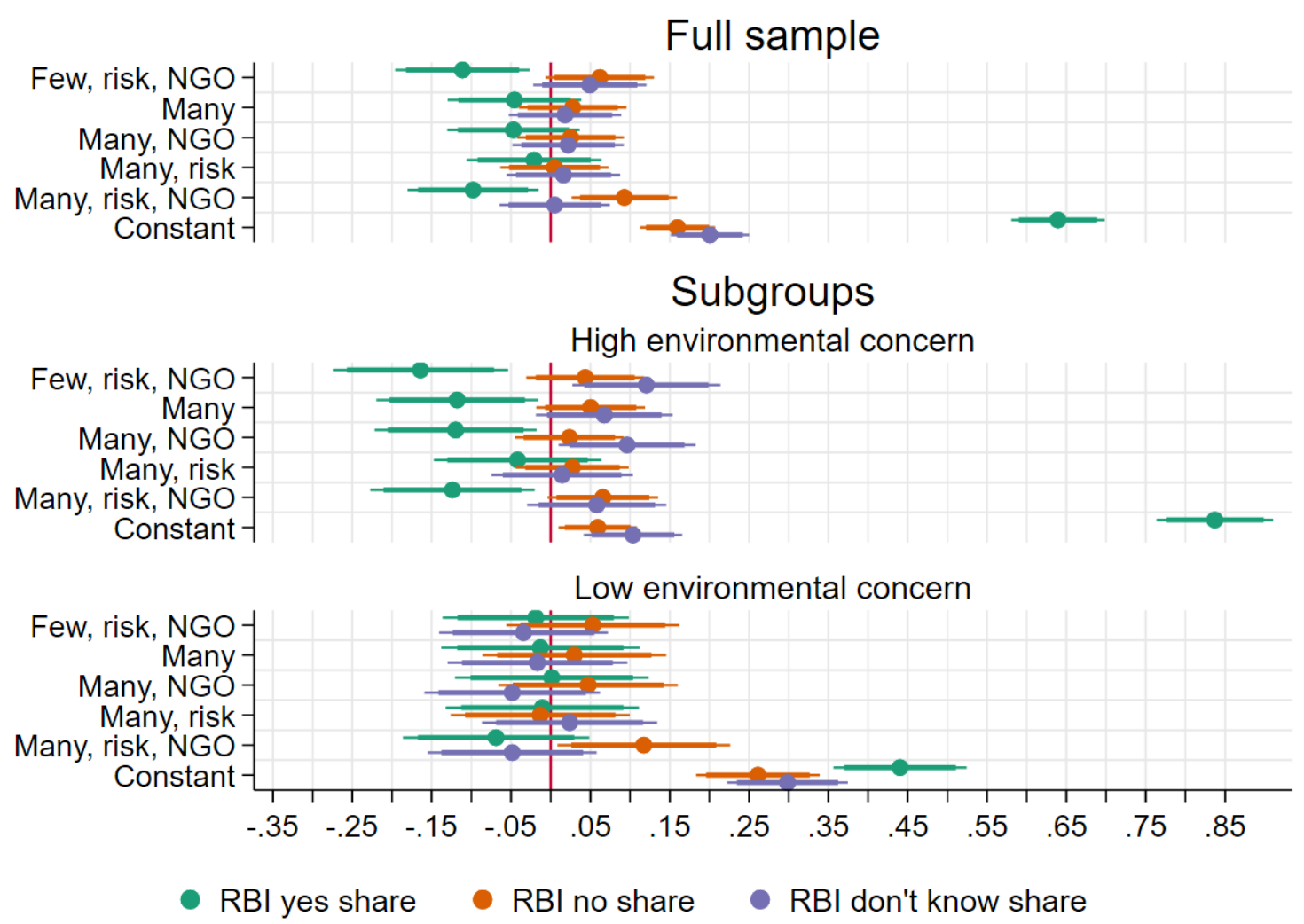

Figure A.5: Full sample and subgroup-analysis (subgroup indicated in header, as defined in the beginning of Appendix Section A.3, for treatment effect estimates of vignette conditions relative to the placebo group on outcome variable 'RBI support'. Constant shows baseline levels of yes/no/don't know shares. Whiskers report $95 \%$ and $90 \%$ confidence intervals. 


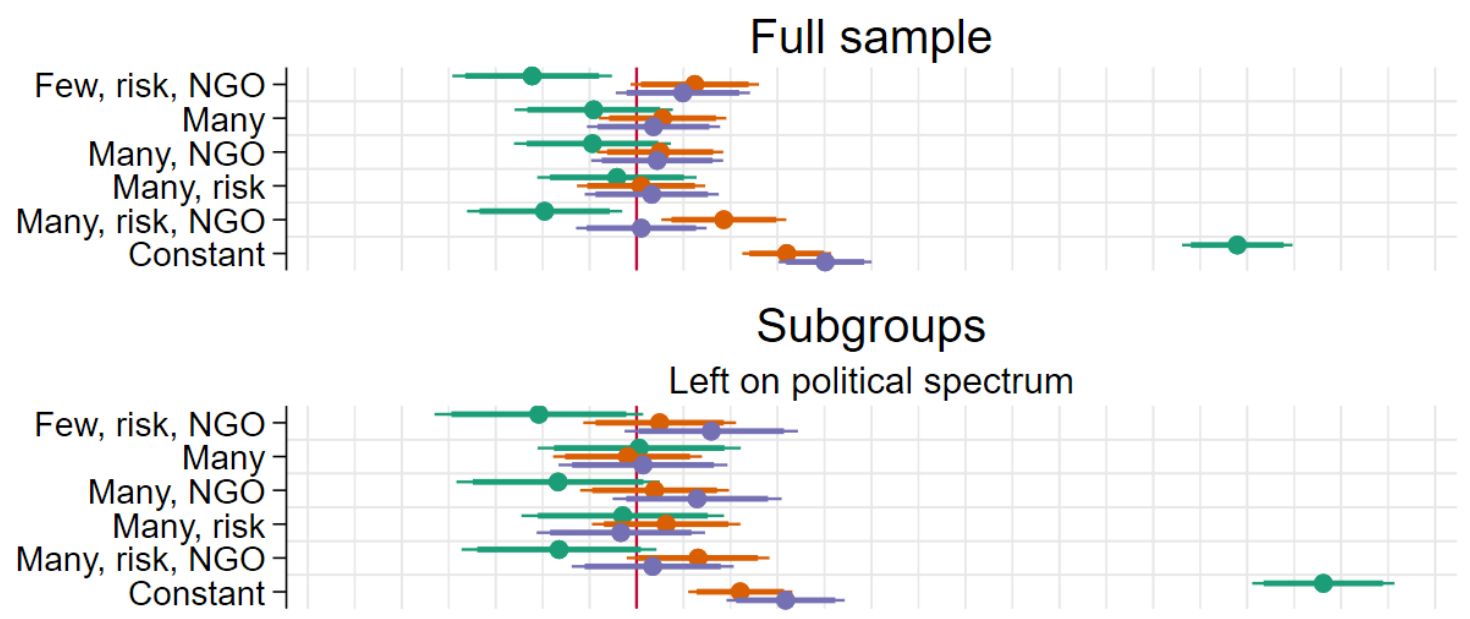

Right on political spectrum

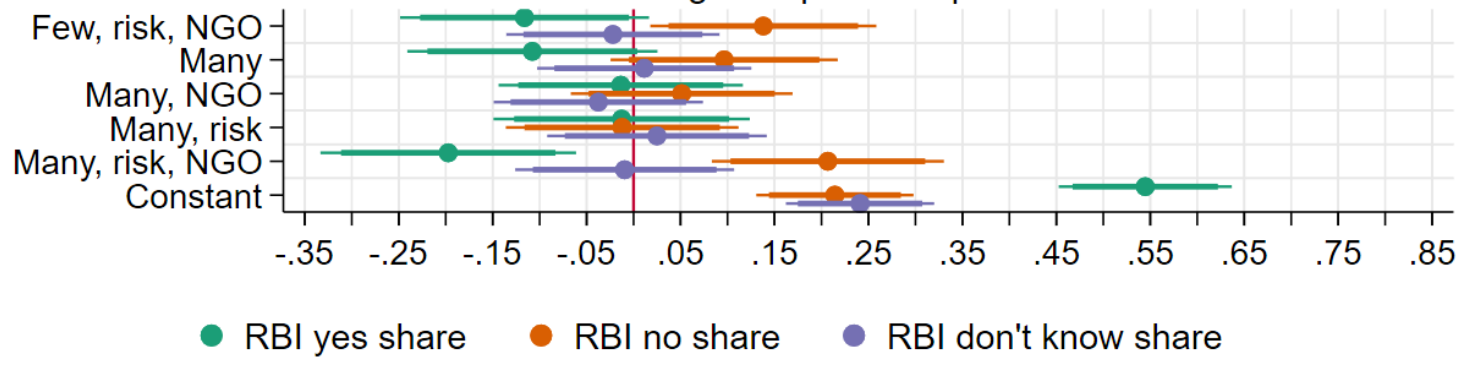

Figure A.6: Full sample and subgroup-analysis (subgroup indicated in header, as defined in the beginning of Appendix Section A.3, for treatment effect estimates of vignette conditions relative to the placebo group on outcome variable 'RBI support'. Constant shows baseline levels of yes/no/don't know shares. Whiskers report $95 \%$ and $90 \%$ confidence intervals. 

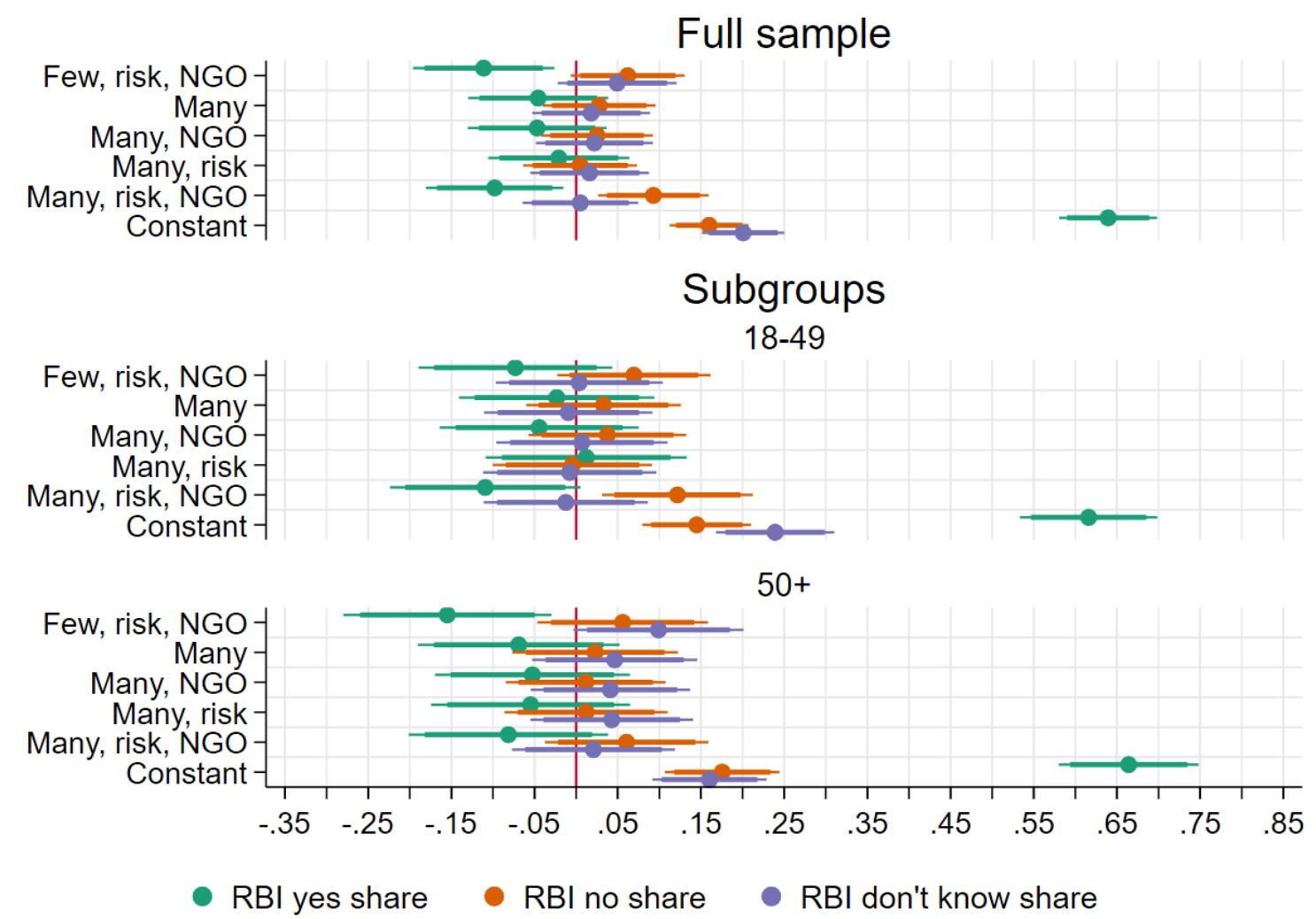

Figure A.7: Full sample and subgroup-analysis (subgroup indicated in header, as defined in the beginning of Appendix Section A.3, for treatment effect estimates of vignette conditions relative to the placebo group on outcome variable 'RBI support'. Constant shows baseline levels of yes/no/don't know shares. Whiskers report $95 \%$ and $90 \%$ confidence intervals. 

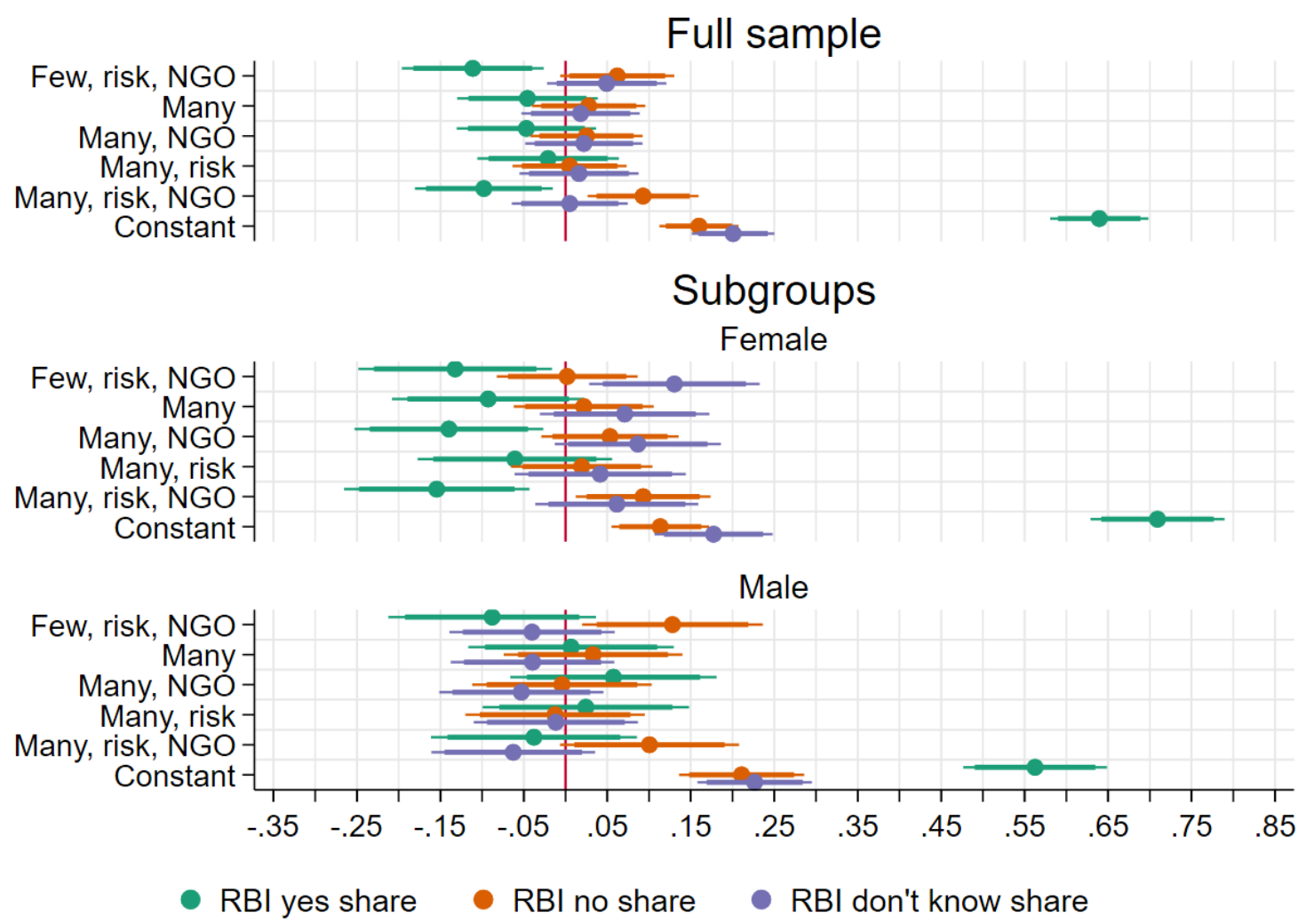

Figure A.8: Full sample and subgroup-analysis (subgroup indicated in header, as defined in the beginning of Appendix Section A.3, for treatment effect estimates of vignette conditions relative to the placebo group on outcome variable 'RBI support'. Constant shows baseline levels of yes/no/don't know shares. Whiskers report $95 \%$ and $90 \%$ confidence intervals. 


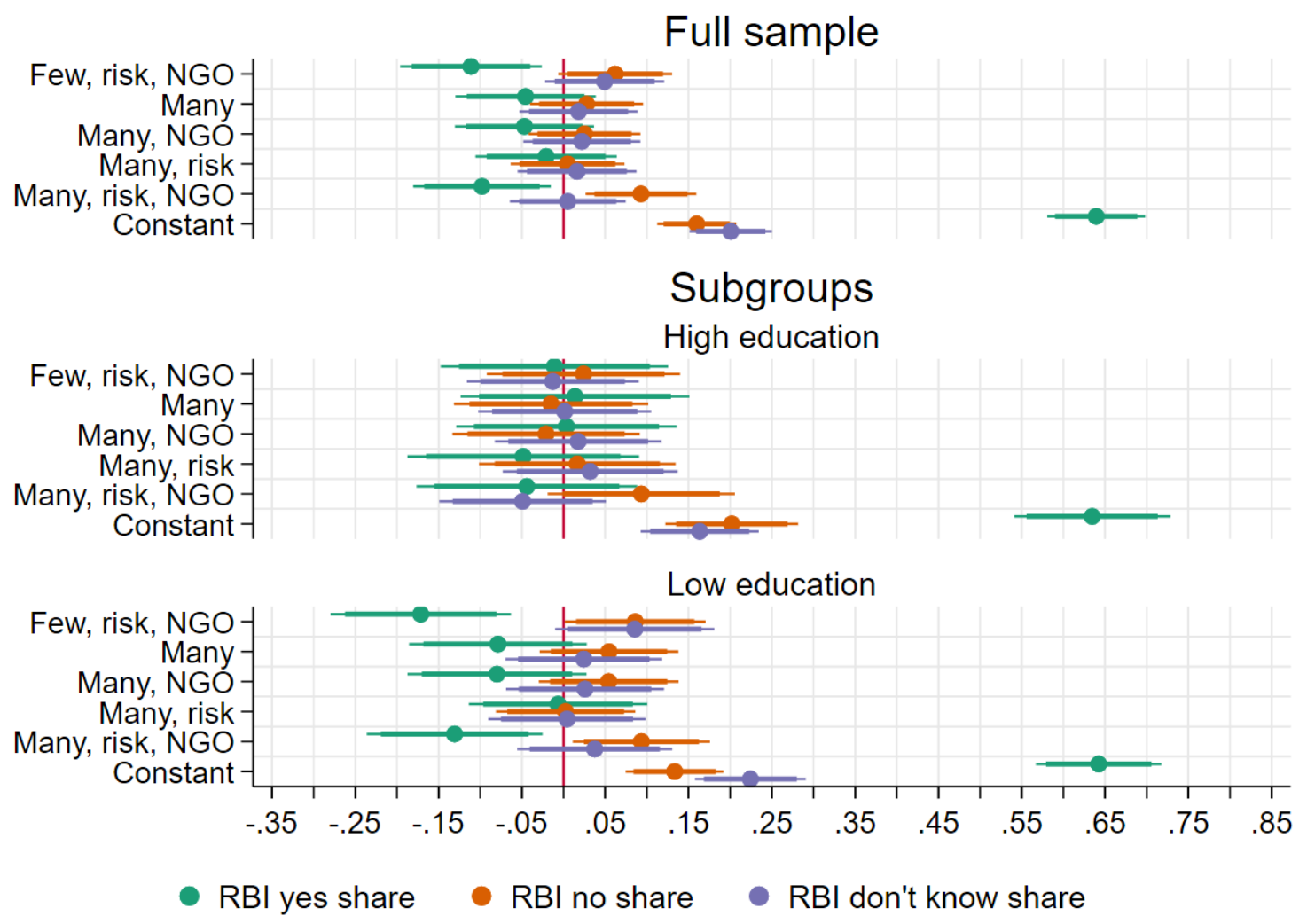

Figure A.9: Full sample and subgroup-analysis (subgroup indicated in header, as defined in the beginning of Appendix Section A.3, for treatment effect estimates of vignette conditions relative to the placebo group on outcome variable 'RBI support'. Constant shows baseline levels of yes/no/don't know shares. Whiskers report $95 \%$ and $90 \%$ confidence intervals. 


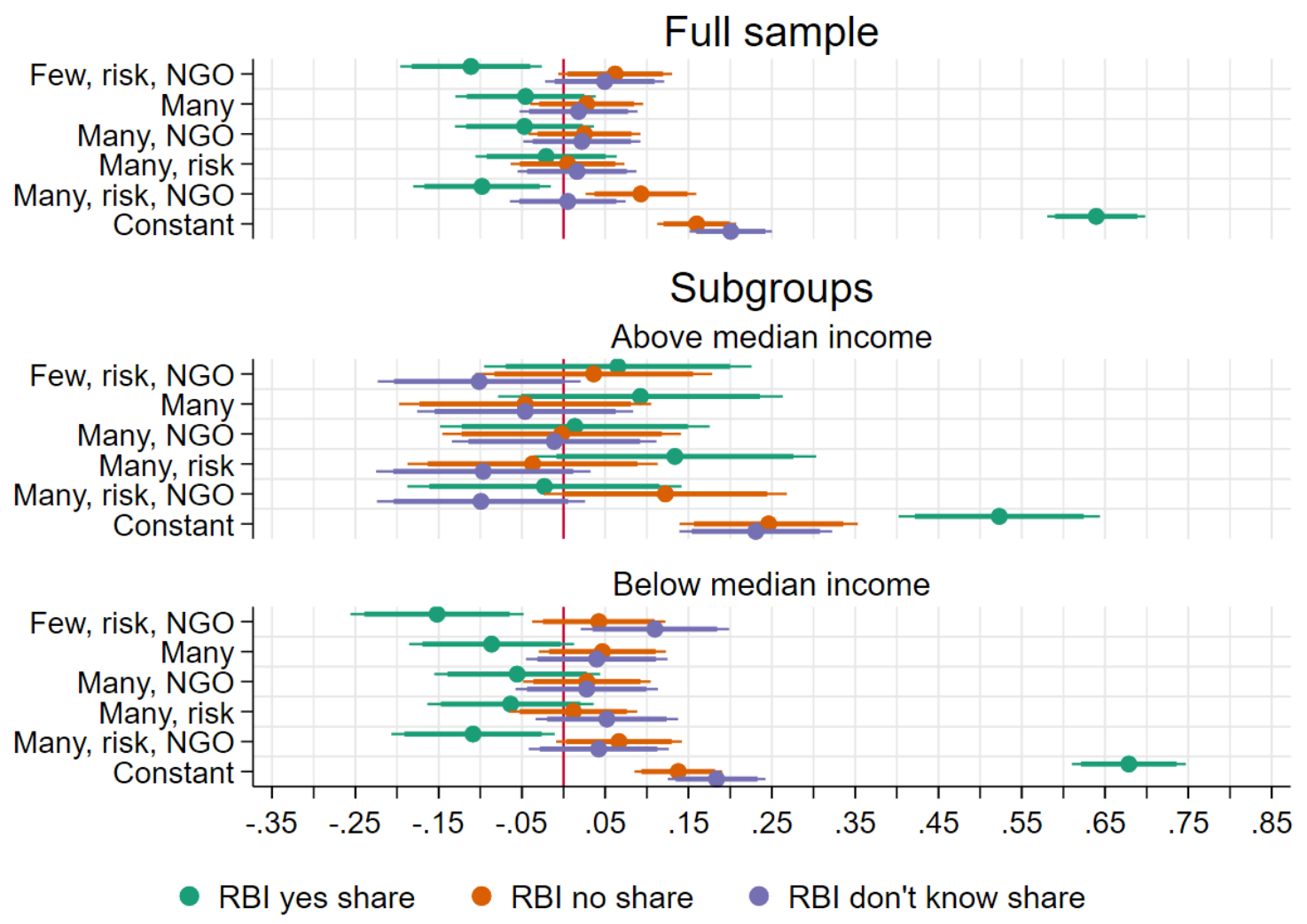

Figure A.10: Full sample and subgroup-analysis (subgroup indicated in header, as defined in the beginning of Appendix Section A.3, for treatment effect estimates of vignette conditions relative to the placebo group on outcome variable 'RBI support'. Constant shows baseline levels of yes/no/don't know shares. Whiskers report $95 \%$ and $90 \%$ confidence intervals. 


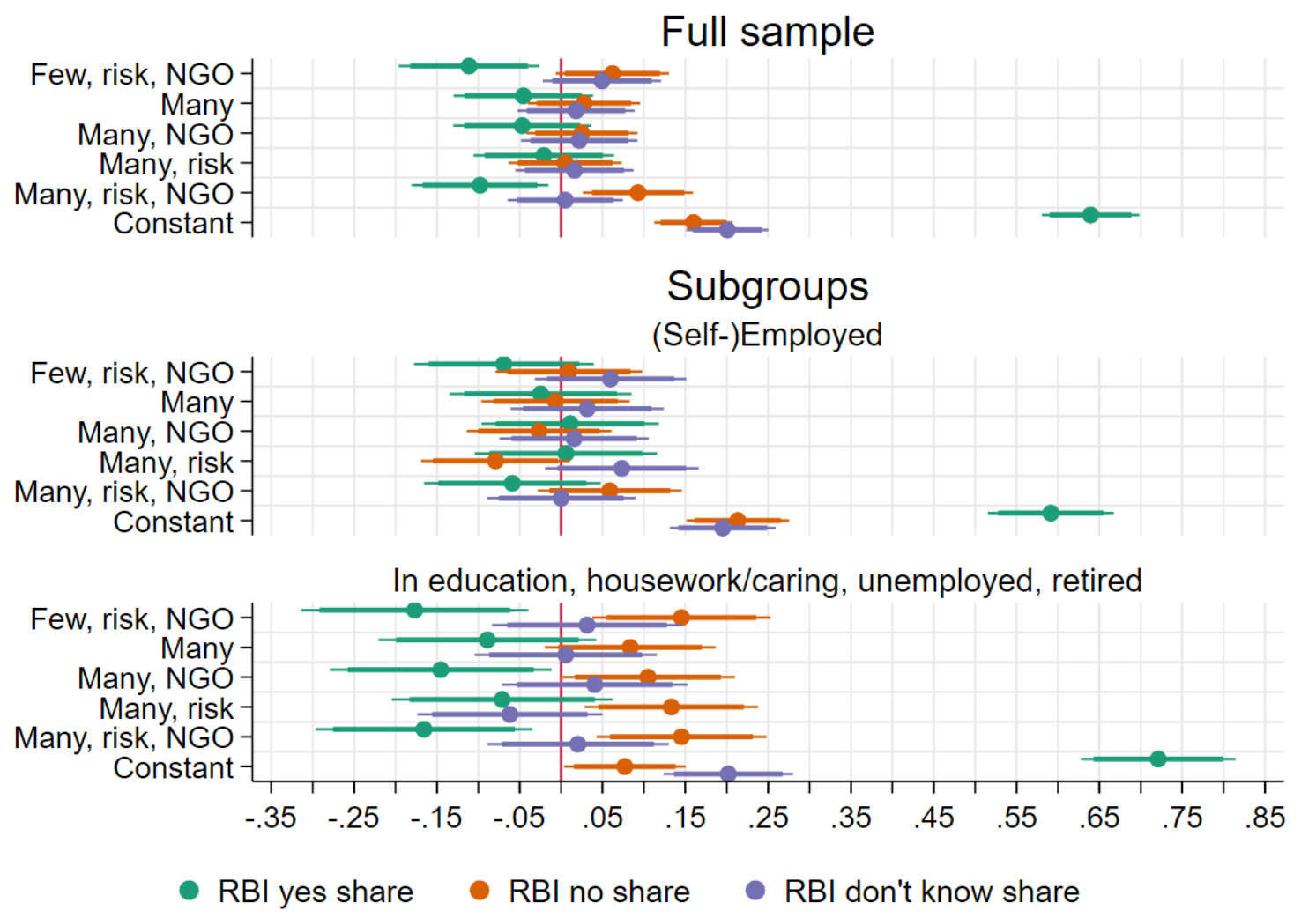

Figure A.11: Full sample and subgroup-analysis (subgroup indicated in header, as defined in the beginning of Appendix Section A.3, for treatment effect estimates of vignette conditions relative to the placebo group on outcome variable 'RBI support'. Constant shows baseline levels of yes/no/don't know shares. Whiskers report $95 \%$ and $90 \%$ confidence intervals. 

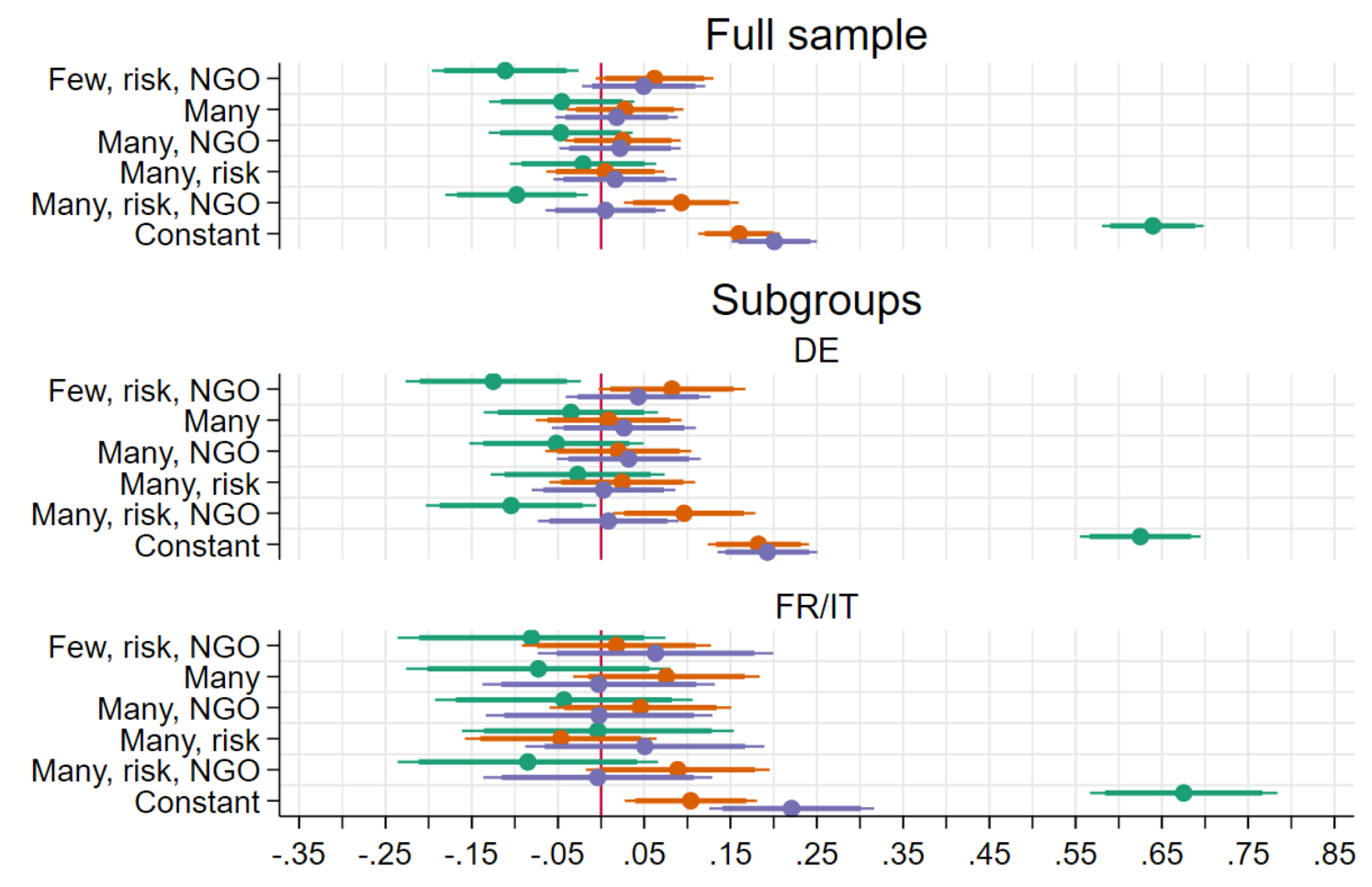

RBI yes share $\quad \mathrm{RBI}$ no share $\mathrm{RBI}$ don't know share

Figure A.12: Full sample and subgroup-analysis (subgroup indicated in header, as defined in the beginning of Appendix Section A.3, for treatment effect estimates of vignette conditions relative to the placebo group on outcome variable 'RBI support'. Constant shows baseline levels of yes/no/don't know shares. Whiskers report $95 \%$ and $90 \%$ confidence intervals. 


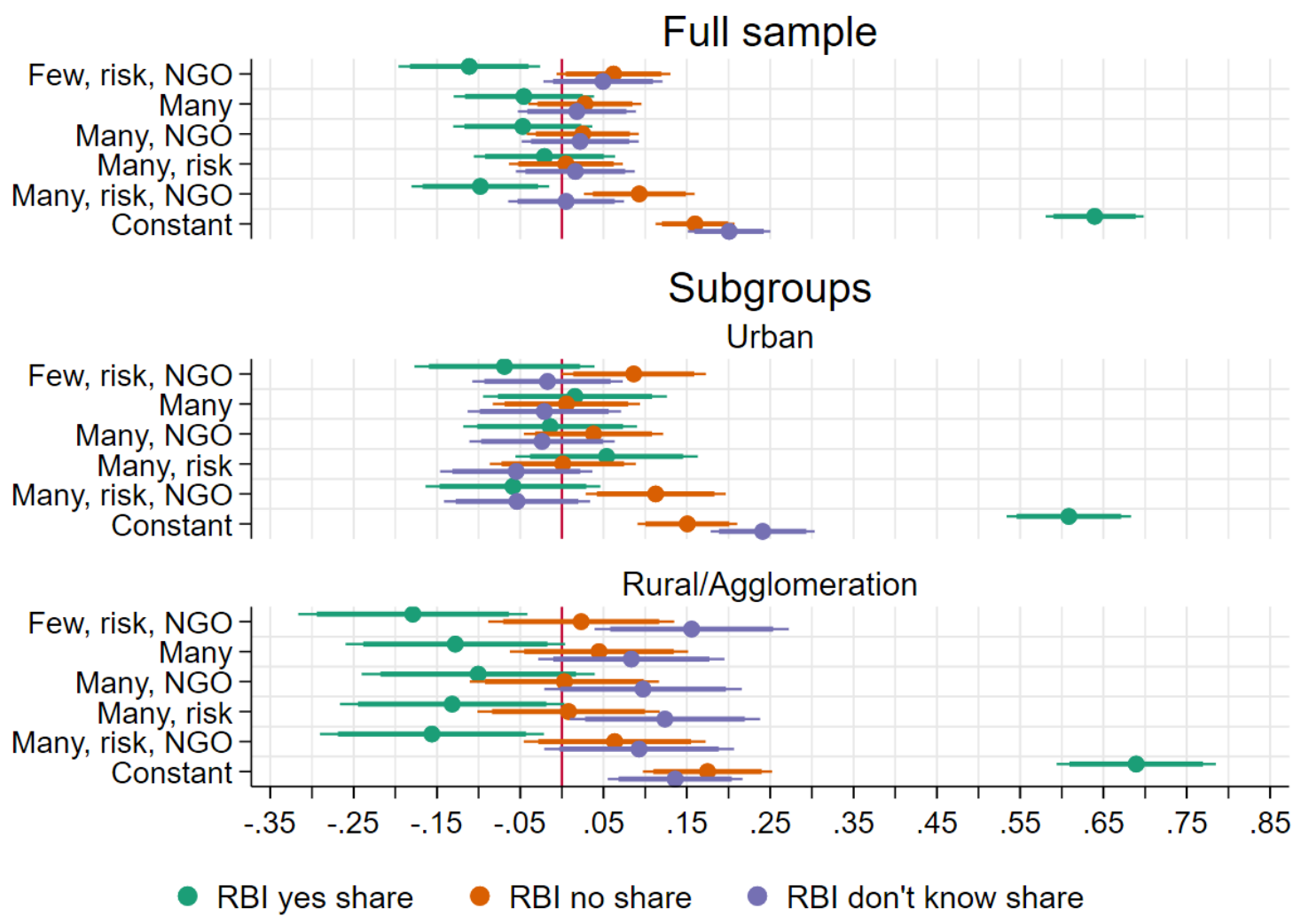

Figure A.13: Full sample and subgroup-analysis (subgroup indicated in header, as defined in the beginning of Appendix Section A.3, for treatment effect estimates of vignette conditions relative to the placebo group on outcome variable 'RBI support'. Constant shows baseline levels of yes/no/don't know shares. Whiskers report $95 \%$ and $90 \%$ confidence intervals. 


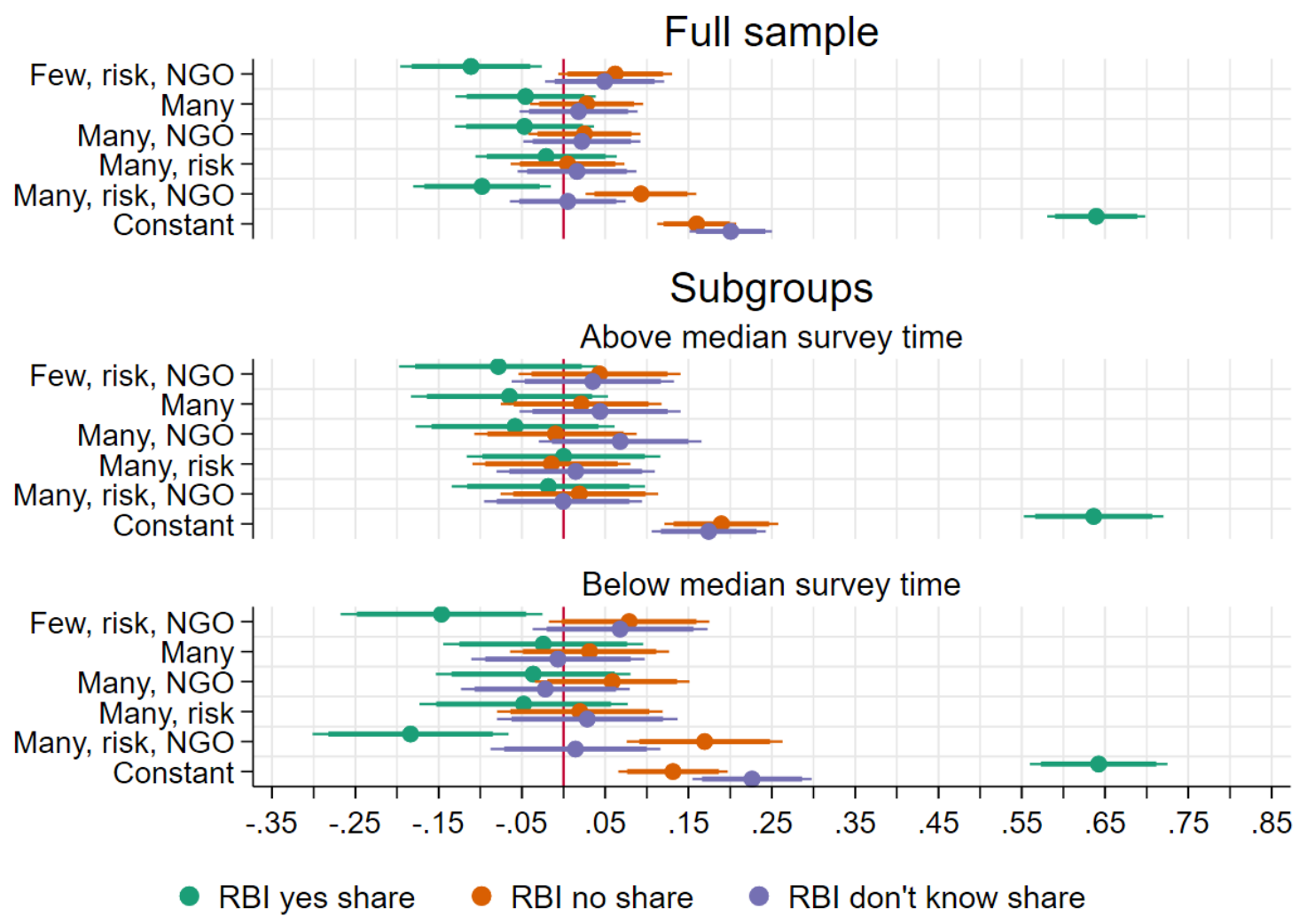

Figure A.14: Full sample and subgroup-analysis (subgroup indicated in header, as defined in the beginning of Appendix Section A.3, for treatment effect estimates of vignette conditions relative to the placebo group on outcome variable 'RBI support'. Constant shows baseline levels of yes/no/don't know shares. Whiskers report $95 \%$ and $90 \%$ confidence intervals. 


\section{A.4 Treatment Mechanisms}

Given our main findings, the following section addresses why some vignettes might move respondent opinions more compared to others. Appendix Table A.7 reports results from a model including control variables, Appendix Table A.8 shows, for comparison, that our results hold in models without control variables as well. Finally, Appendix Table A.9 displays results for the particular subgroup of individuals with/without high likelihood of voting (as discussed in the Section 5.2.3 of the main text) and Appendix Table A.10 for the particular subgroup of individuals with/without prior knowledge of the RBI (as discussed in Appendix Section A.3.

These tables are structured as follows: Model 1 (6) has as dependent variable the question of whether voluntary corporate initiatives are merely green window-dressing - hence, making the firms appear environment-friendly, but not addressing potential issues in a meaningful manner. In tendency, the vignettes including both high-risk firms and NGO oversight, move respondents to disagree here, particularly the vignette containing many only slightly to the positive. This could be one explanation of why the vignettes work: Where risk-firms and oversight are included, overall corporate measures are perceived to be serious and credible. Note, however, that coefficients do not differ significantly between vignettes and are significantly different from zero in only one case.

Model 2 (7) measures the effects of our treatments on the perception that voluntary corporate initiatives are costly for corporations. This is consistently so (and coefficients are statistically different from zero at the $5 \%$ (model 2 and model 7 ) level) where only a few firms engage in these measures.

Model 3 (8) tests whether participants perceive voluntary initiatives to indicate that corporations care a lot about the protection of people and the environment abroad. Where respondents receive the few, risk, NGO-vignette, they are significantly more likely to 
interpret voluntary measures in this light.

Model 4 (9) summarises the effect of our treatments on whether participants perceive voluntary initiatives to be proof that corporations cause social and environmental harm. In tendency, coefficients are positive but do only for some coefficients reach statistical significance.

Finally, model 5 (10) shows whether participants think that voluntary initiatives prevent societal bureaucratic costs depending on the treatment conditions. In tendency, as soon as 'many' firms are included in the vignette, coefficients are positive. Again, they do only for some vignettes reach statistical significance.

Overall, results point into a direction where voluntary measures are a stronger signal when both risk-firms and NGO oversight are included, albeit costly for companies. This is in line with the findings mentioned above. However, both a small coefficient size and a lack of statistical power do not allow us to draw definite conclusions here. 
Table A.7: Mechanisms by which voluntary firm behaviour affects public support

\begin{tabular}{|c|c|c|c|c|c|c|c|c|c|c|}
\hline & (1) & (2) & $\begin{array}{l}\text { Pure samp } \\
\text { (3) }\end{array}$ & le & (5) & (6) & (7) & $\begin{array}{l}\text { Full samp } \\
\text { (8) }\end{array}$ & le & $(10)$ \\
\hline & Window dressing & VM costly & Signal caring firms & Indicate damage & Prevent regulatory costs & Window dressing & VM costly & Signal caring firms & Indicate damage & Prevent regulatory costs \\
\hline Few, risk, NGO & $\begin{array}{l}-0.04 \\
(0.10)\end{array}$ & $\begin{array}{l}0.19^{*} \\
(0.10)\end{array}$ & $\begin{array}{l}0.23^{*} \\
(0.10)\end{array}$ & $\begin{array}{l}-0.00 \\
(0.10)\end{array}$ & $\begin{array}{l}-0.05 \\
(0.10)\end{array}$ & $\begin{array}{l}-0.03 \\
(0.07)\end{array}$ & $\begin{array}{l}0.20^{* *} \\
(0.07)\end{array}$ & $\begin{array}{l}0.13^{*} \\
(0.07)\end{array}$ & $\begin{array}{l}-0.03 \\
(0.07)\end{array}$ & $\begin{array}{l}-0.02 \\
(0.07)\end{array}$ \\
\hline Many & $\begin{array}{c}0.02 \\
(0.10)\end{array}$ & $\begin{array}{l}-0.01 \\
(0.10)\end{array}$ & $\begin{array}{l}-0.06 \\
(0.09)\end{array}$ & $\begin{array}{c}0.02 \\
(0.10)\end{array}$ & $\begin{array}{c}0.03 \\
(0.10)\end{array}$ & $\begin{array}{c}0.04 \\
(0.07)\end{array}$ & $\begin{array}{c}0.01 \\
(0.07)\end{array}$ & $\begin{array}{l}-0.04 \\
(0.07)\end{array}$ & $\begin{array}{c}0.03 \\
(0.07)\end{array}$ & $\begin{array}{c}0.11 \\
(0.07)\end{array}$ \\
\hline Many, NGO & $\begin{array}{c}0.14 \\
(0.10)\end{array}$ & $\begin{array}{c}0.14 \\
(0.10)\end{array}$ & $\begin{array}{l}-0.02 \\
(0.09)\end{array}$ & $\begin{array}{c}0.15 \\
(0.10)\end{array}$ & $\begin{array}{c}0.05 \\
(0.10)\end{array}$ & $\begin{array}{l}-0.06 \\
(0.07)\end{array}$ & $\begin{array}{c}0.04 \\
(0.07)\end{array}$ & $\begin{array}{c}0.04 \\
(0.07)\end{array}$ & $\begin{array}{c}0.09 \\
(0.07)\end{array}$ & $\begin{array}{c}0.07 \\
(0.07)\end{array}$ \\
\hline Many, risk & $\begin{array}{l}0.12 \\
(0.10)\end{array}$ & $\begin{array}{l}0.29^{* *} \\
(0.10)\end{array}$ & $\begin{array}{l}0.07 \\
(0.09)\end{array}$ & $\begin{array}{l}0.20^{*} \\
(0.10)\end{array}$ & $\begin{array}{c}0.08 \\
(0.10)\end{array}$ & $\begin{array}{l}-0.08 \\
(0.07)\end{array}$ & $\begin{array}{l}0.16^{*} \\
(0.07)\end{array}$ & $\begin{array}{c}0.07 \\
(0.07)\end{array}$ & $\begin{array}{c}0.05 \\
(0.07)\end{array}$ & $\begin{array}{l}0.18^{*} \\
(0.07)\end{array}$ \\
\hline Many, risk, NGO & $\begin{array}{l}-0.04 \\
(0.09)\end{array}$ & $\begin{array}{c}0.14 \\
(0.09)\end{array}$ & $\begin{array}{c}0.05 \\
(0.09)\end{array}$ & $\begin{array}{c}0.07 \\
(0.10)\end{array}$ & $\begin{array}{c}0.09 \\
(0.10)\end{array}$ & $\begin{array}{r}-0.12^{+} \\
(0.07)\end{array}$ & $\begin{array}{c}0.08 \\
(0.07)\end{array}$ & $\begin{array}{c}0.03 \\
(0.07)\end{array}$ & $\begin{array}{c}0.01 \\
(0.07)\end{array}$ & $\begin{array}{c}0.04 \\
(0.07)\end{array}$ \\
\hline Constant & $\begin{array}{l}4.00^{* * * *} \\
(0.62)\end{array}$ & $\begin{array}{l}4.05^{* * *} \\
(0.61)\end{array}$ & $\begin{array}{c}2.34^{* * *} \\
(0.61)\end{array}$ & $\begin{array}{l}4.89^{* * *} \\
(0.62)\end{array}$ & $\begin{array}{c}3.17^{* * *} \\
(0.63)\end{array}$ & $\begin{array}{c}3.69^{* * *} \\
(0.58)\end{array}$ & $\begin{array}{l}4.11^{* * *} \\
(0.56)\end{array}$ & $\begin{array}{c}2.31^{* * *} \\
(0.56)\end{array}$ & $\begin{array}{l}4.07^{* * *} \\
(0.58)\end{array}$ & $\begin{array}{c}2.78^{* * *} \\
(0.58)\end{array}$ \\
\hline Controls & Yes & Yes & Yes & Yes & Yes & Yes & Yes & Yes & Yes & Yes \\
\hline & 1404.00 & 1367.00 & 1443.00 & 1369.00 & 1361.00 & 2674.00 & 2618.00 & 2761.00 & 2616.00 & 2602.00 \\
\hline r2_a & 0.06 & 0.05 & 0.05 & 0.09 & 0.03 & 0.04 & 0.06 & 0.05 & 0.06 & 0.03 \\
\hline Control_mean & 3.11 & 3.06 & 3.41 & 2.84 & 3.32 & 3.12 & 3.14 & 3.52 & 2.82 & 3.30 \\
\hline Control_sd & 1.10 & 0.96 & 1.12 & 1.15 & 1.07 & 1.09 & 1.03 & 1.09 & 1.09 & 1.04 \\
\hline
\end{tabular}


Table A.8: Mechanisms by which voluntary firm behaviour affects public opinion - results without control variables

\begin{tabular}{|c|c|c|c|c|c|c|c|c|c|c|}
\hline & \multicolumn{5}{|c|}{$\begin{array}{l}\text { Pure sample } \\
\end{array}$} & \multicolumn{5}{|c|}{ Full sample } \\
\hline & (1) & $(2)$ & (3) & (4) & (5) & $(6)$ & (7) & (8) & (9) & (10) \\
\hline & Window dressing & VM costly & Signal caring firms & Indicate damage & Prevent regulatory costs & Window dressing & VM costly & Signal caring firms & Indicate damage & Prevent regulatory costs \\
\hline Few, risk, NGO & $\begin{array}{c}-0.05 \\
(0.10)\end{array}$ & $\begin{array}{l}0.16^{+} \\
(0.09)\end{array}$ & $\begin{array}{l}0.19^{*} \\
(0.09)\end{array}$ & $\begin{array}{c}0.01 \\
(0.10)\end{array}$ & $\begin{array}{c}-0.08 \\
(0.09)\end{array}$ & $\begin{array}{c}-0.01 \\
(0.07)\end{array}$ & $\begin{array}{c}0.16^{*} \\
(0.07)\end{array}$ & $\begin{array}{c}0.09 \\
(0.07)\end{array}$ & $\begin{array}{c}-0.02 \\
(0.07)\end{array}$ & $\begin{array}{l}-0.05 \\
0.07)\end{array}$ \\
\hline Many & $\begin{array}{c}-0.02 \\
(0.10)\end{array}$ & $\begin{array}{c}0.00 \\
(0.09)\end{array}$ & $\begin{array}{l}-0.09 \\
(0.09)\end{array}$ & $\begin{array}{c}0.03 \\
(0.10)\end{array}$ & $\begin{array}{c}0.01 \\
(0.09)\end{array}$ & $\begin{array}{c}0.04 \\
(0.07)\end{array}$ & $\begin{array}{l}-0.02 \\
(0.07)\end{array}$ & $\begin{array}{c}-0.09 \\
(0.07)\end{array}$ & $\begin{array}{c}0.07 \\
(0.07)\end{array}$ & $\begin{array}{c}0.06 \\
(0.07)\end{array}$ \\
\hline Many, NGO & $\begin{array}{c}0.09 \\
(0.09)\end{array}$ & $\begin{array}{c}0.11 \\
(0.09)\end{array}$ & $\begin{array}{c}-0.04 \\
(0.09)\end{array}$ & $\begin{array}{c}0.12 \\
(0.10)\end{array}$ & $\begin{array}{c}0.03 \\
(0.09)\end{array}$ & $\begin{array}{l}-0.05 \\
(0.07)\end{array}$ & $\begin{array}{c}-0.00 \\
(0.07)\end{array}$ & $\begin{array}{c}-0.00 \\
(0.07)\end{array}$ & $\begin{array}{c}0.10 \\
(0.07)\end{array}$ & $\begin{array}{c}0.01 \\
(0.07)\end{array}$ \\
\hline Many, risk & $\begin{array}{c}0.07 \\
(0.10)\end{array}$ & $\begin{array}{l}0.24^{*} \\
(0.09)\end{array}$ & $\begin{array}{c}0.05 \\
(0.09)\end{array}$ & $\begin{array}{l}0.18^{+} \\
(0.10)\end{array}$ & $\begin{array}{c}0.08 \\
(0.10)\end{array}$ & $\begin{array}{c}-0.10 \\
(0.07)\end{array}$ & $\begin{array}{l}0.11^{+} \\
(0.07)\end{array}$ & $\begin{array}{c}0.03 \\
(0.07)\end{array}$ & $\begin{array}{c}0.06 \\
(0.07)\end{array}$ & $\begin{array}{l}0.13^{+} \\
(0.07)\end{array}$ \\
\hline Many, risk, NGO & $\begin{array}{c}-0.05 \\
(0.09)\end{array}$ & $\begin{array}{c}0.14 \\
(0.09)\end{array}$ & $\begin{array}{c}0.00 \\
(0.09)\end{array}$ & $\begin{array}{c}0.08 \\
(0.10)\end{array}$ & $\begin{array}{c}0.06 \\
(0.09)\end{array}$ & $\begin{array}{c}-0.10 \\
(0.07)\end{array}$ & $\begin{array}{c}0.05 \\
(0.07)\end{array}$ & $\begin{array}{l}-0.03 \\
(0.07)\end{array}$ & $\begin{array}{c}0.03 \\
(0.07)\end{array}$ & $\begin{array}{c}-0.01 \\
(0.07)\end{array}$ \\
\hline Constant & $\begin{array}{c}3.11^{* * *} \\
(0.07)\end{array}$ & $\begin{array}{c}3.06^{* * *} \\
(0.07)\end{array}$ & $\begin{array}{c}3.41^{* * *} \\
(0.06)\end{array}$ & $\begin{array}{c}2.84^{* * *} \\
(0.07)\end{array}$ & $\begin{array}{c}3.32^{* * *} \\
(0.07)\end{array}$ & $\begin{array}{c}3.12^{2 * *} \\
(0.05)\end{array}$ & $\begin{array}{c}3.14^{* * *} \\
(0.05)\end{array}$ & $\begin{array}{c}3.52^{* * *} \\
(0.05)\end{array}$ & $\begin{array}{c}2.82^{* * *} \\
(0.05)\end{array}$ & $\begin{array}{c}3.30^{* * *} \\
(0.05)\end{array}$ \\
\hline $\mathrm{N}$ & 1476.00 & 1437.00 & 1524.00 & 1437.00 & 1429.00 & 2829.00 & 2774.00 & 2935.00 & 2769.00 & 2751.00 \\
\hline $\mathrm{r} 2{ }_{-}^{\mathrm{a}}$ & -0.00 & 0.00 & 0.00 & 0.00 & -0.00 & 0.00 & 0.00 & 0.00 & -0.00 & 0.00 \\
\hline Control_mean & 3.11 & 3.06 & 3.41 & 2.84 & 3.32 & 3.12 & 3.14 & 3.52 & 2.82 & 3.30 \\
\hline Control_sd & 1.10 & 0.96 & 1.12 & 1.15 & 1.07 & 1.09 & 1.03 & 1.09 & 1.09 & 1.04 \\
\hline
\end{tabular}


Table A.9: Mechanisms by which voluntary firm behaviour affects public opinion - high and low probability of voting group

\begin{tabular}{|c|c|c|c|c|c|c|c|c|c|c|}
\hline & $\begin{array}{c}(1) \\
\text { Window dressing }\end{array}$ & $\begin{array}{c}(2) \\
\text { VM costly }\end{array}$ & $\begin{array}{c}\text { High voting pro } \\
\text { (3) } \\
\text { Signal caring firms }\end{array}$ & $\begin{array}{l}\text { bability } \\
\text { (4) } \\
\text { Indicate damage }\end{array}$ & $\begin{array}{c}(5) \\
\text { Prevent regulatory costs }\end{array}$ & $\begin{array}{c}(6) \\
\text { Window dressing }\end{array}$ & $\begin{array}{c}(7) \\
\text { VM costly }\end{array}$ & $\begin{array}{l}\text { Low voting prol } \\
\text { (8) } \\
\text { Signal caring firms }\end{array}$ & $\begin{array}{l}\text { bability } \\
\text { (9) } \\
\text { Indicate damage }\end{array}$ & $\begin{array}{c}(10) \\
\text { Prevent regulatory costs }\end{array}$ \\
\hline Few, risk, NGO & $\begin{array}{l}-0.18 \\
(0.12)\end{array}$ & $\begin{array}{l}0.31^{* *} \\
(0.12)\end{array}$ & $\begin{array}{l}0.29^{*} \\
(0.12)\end{array}$ & $\begin{array}{l}-0.08 \\
(0.12)\end{array}$ & $\begin{array}{l}-0.02 \\
(0.12)\end{array}$ & $\begin{array}{c}0.27 \\
(0.18)\end{array}$ & $\begin{array}{l}-0.05 \\
(0.18)\end{array}$ & $\begin{array}{c}0.14 \\
(0.17)\end{array}$ & $\begin{array}{c}0.16 \\
(0.18)\end{array}$ & $\begin{array}{c}0.00 \\
(0.19)\end{array}$ \\
\hline Many & $\begin{array}{l}-0.02 \\
(0.12)\end{array}$ & $\begin{array}{c}0.05 \\
(0.12)\end{array}$ & $\begin{array}{l}-0.09 \\
(0.12)\end{array}$ & $\begin{array}{l}-0.05 \\
(0.12)\end{array}$ & $\begin{array}{c}0.08 \\
(0.12)\end{array}$ & $\begin{array}{c}0.12 \\
(0.17)\end{array}$ & $\begin{array}{l}-0.08 \\
(0.17)\end{array}$ & $\begin{array}{c}0.01 \\
(0.16)\end{array}$ & $\begin{array}{c}0.15 \\
(0.18)\end{array}$ & $\begin{array}{c}0.01 \\
(0.18)\end{array}$ \\
\hline Many, NGO & $\begin{array}{l}0.05 \\
(0.12)\end{array}$ & $\begin{array}{l}0.15 \\
(0.11)\end{array}$ & $\begin{array}{l}-0.01 \\
(0.11)\end{array}$ & $\begin{array}{c}0.13 \\
(0.12)\end{array}$ & $\begin{array}{l}0.07 \\
(0.11)\end{array}$ & $\begin{array}{l}0.30^{+} \\
(0.17)\end{array}$ & $\begin{array}{c}0.08 \\
(0.18)\end{array}$ & $\begin{array}{l}-0.02 \\
(0.17)\end{array}$ & $\begin{array}{c}0.12 \\
(0.18)\end{array}$ & $\begin{array}{c}0.02 \\
(0.19)\end{array}$ \\
\hline Many, risk & $\begin{array}{c}0.11 \\
(0.12)\end{array}$ & $\begin{array}{l}0.34^{* *} \\
(0.12)\end{array}$ & $\begin{array}{c}0.09 \\
(0.12)\end{array}$ & $\begin{array}{l}0.17 \\
(0.12)\end{array}$ & $\begin{array}{l}0.07 \\
(0.12)\end{array}$ & $\begin{array}{c}0.12 \\
(0.18)\end{array}$ & $\begin{array}{c}0.23 \\
(0.18)\end{array}$ & $\begin{array}{l}-0.05 \\
(0.17)\end{array}$ & $\begin{array}{l}0.32^{+} \\
(0.19)\end{array}$ & $\begin{array}{c}0.14 \\
(0.19)\end{array}$ \\
\hline Many, risk, NGO & $\begin{array}{l}-0.04 \\
(0.11)\end{array}$ & $\begin{array}{l}0.19^{+} \\
(0.11)\end{array}$ & $\begin{array}{c}0.00 \\
(0.11)\end{array}$ & $\begin{array}{c}0.01 \\
(0.11)\end{array}$ & $\begin{array}{c}0.12 \\
(0.11)\end{array}$ & $\begin{array}{l}-0.04 \\
(0.17)\end{array}$ & $\begin{array}{c}0.08 \\
(0.18)\end{array}$ & $\begin{array}{c}0.14 \\
(0.17)\end{array}$ & $\begin{array}{c}0.21 \\
(0.18)\end{array}$ & $\begin{array}{c}0.02 \\
(0.18)\end{array}$ \\
\hline Constant & $\begin{array}{l}4.69^{* * *} \\
(0.79)\end{array}$ & $\begin{array}{c}3.60^{* * *} \\
(0.78)\end{array}$ & $\begin{array}{c}2.59^{* * *} \\
(0.78)\end{array}$ & $\begin{array}{l}4.97^{* * *} \\
(0.78)\end{array}$ & $\begin{array}{l}2.84^{* * *} \\
(0.79)\end{array}$ & $\begin{array}{l}2.88^{* *} \\
(1.09)\end{array}$ & $\begin{array}{l}3.95^{* * *} \\
(1.11)\end{array}$ & $\begin{array}{l}1.93^{+} \\
(1.07)\end{array}$ & $\begin{array}{l}5.06^{* * *} \\
(1.14)\end{array}$ & $\begin{array}{l}2.72^{*} \\
(1.17)\end{array}$ \\
\hline Controls & Yes & Yes & Yes & Yes & Yes & Yes & Yes & Yes & Yes & Yes \\
\hline $\mathrm{N}$ & 997.00 & 977.00 & 1025.00 & 975.00 & 968.00 & 407.00 & 390.00 & 418.00 & 394.00 & 393.00 \\
\hline r2_-a & 0.09 & 0.07 & 0.06 & 0.11 & 0.04 & 0.02 & 0.01 & 0.05 & 0.07 & 0.01 \\
\hline Control_mean & 3.16 & 3.01 & 3.39 & 2.92 & 3.32 & 2.99 & 3.20 & 3.47 & 2.67 & 3.33 \\
\hline Control_sd & 1.15 & 0.98 & 1.17 & 1.20 & 1.10 & 0.97 & 0.92 & 0.98 & 1.03 & 0.99 \\
\hline
\end{tabular}


Table A.10: Mechanisms by which voluntary firm behaviour affects public opinion - respondents report (not) having heard of the RBI

\begin{tabular}{|c|c|c|c|c|c|c|c|c|c|c|}
\hline & $\begin{array}{c}(1) \\
\text { Window dressing }\end{array}$ & $\begin{array}{c}(2) \\
\text { VM costly }\end{array}$ & $\begin{array}{c}\text { Not having hearc } \\
(3) \\
\text { Signal caring firms }\end{array}$ & $\begin{array}{l}\mathrm{d} \text { of RBI } \\
(4) \\
\text { Indicate damage }\end{array}$ & $\begin{array}{c}(5) \\
\text { Prevent regulatory costs }\end{array}$ & $\begin{array}{c}(6) \\
\text { Window dressing }\end{array}$ & $\begin{array}{c}(7) \\
\text { VM costly }\end{array}$ & $\begin{array}{c}\text { Having heard } \\
(8) \\
\text { Signal caring firms }\end{array}$ & $\begin{array}{l}\text { of RBI } \\
\text { Indicate damage }\end{array}$ & $\begin{array}{l}(10) \\
\text { Prevent regulatory costs }\end{array}$ \\
\hline Few, risk, NGO & $\begin{array}{l}-0.09 \\
(0.11)\end{array}$ & $\begin{array}{c}0.14 \\
(0.12)\end{array}$ & $\begin{array}{c}0.18 \\
(0.11)\end{array}$ & $\begin{array}{c}0.12 \\
(0.12)\end{array}$ & $\begin{array}{c}0.05 \\
0.12) \\
(0.12\end{array}$ & $\begin{array}{c}0.13 \\
(0.19)\end{array}$ & $\begin{array}{c}0.18 \\
(0.18)\end{array}$ & $\begin{array}{l}0.36^{+} \\
(0.18)\end{array}$ & $\begin{array}{l}-0.26 \\
(0.19)\end{array}$ & $\begin{array}{c}-0.31^{+} \\
(0.19)\end{array}$ \\
\hline Many & $\begin{array}{l}-0.03 \\
(0.11)\end{array}$ & $\begin{array}{c}0.02 \\
(0.11)\end{array}$ & $\begin{array}{l}-0.08 \\
(0.11)\end{array}$ & $\begin{array}{c}0.02 \\
(0.11)\end{array}$ & $\begin{array}{c}0.09 \\
(0.11)\end{array}$ & $\begin{array}{c}0.22 \\
(0.19)\end{array}$ & $\begin{array}{l}-0.16 \\
(0.18)\end{array}$ & $\begin{array}{l}-0.04 \\
(0.19)\end{array}$ & $\begin{array}{c}0.02 \\
(0.19)\end{array}$ & $\begin{array}{l}-0.27 \\
(0.19)\end{array}$ \\
\hline Many, NGO & $\begin{array}{c}0.09 \\
(0.11)\end{array}$ & $\begin{array}{c}0.16 \\
(0.11)\end{array}$ & $\begin{array}{c}-0.05 \\
(0.11)\end{array}$ & $\begin{array}{c}0.09 \\
(0.11)\end{array}$ & $\begin{array}{c}0.08 \\
(0.11)\end{array}$ & $\begin{array}{c}0.22 \\
(0.19)\end{array}$ & $\begin{array}{c}0.04 \\
(0.18)\end{array}$ & $\begin{array}{c}0.10 \\
(0.18)\end{array}$ & $\begin{array}{c}0.21 \\
(0.19)\end{array}$ & $\begin{array}{c}0.01 \\
(0.19)\end{array}$ \\
\hline Many, risk & $\begin{array}{c}0.02 \\
(0.11)\end{array}$ & $\begin{array}{l}0.29^{*} \\
(0.11)\end{array}$ & $\begin{array}{c}0.01 \\
(0.11)\end{array}$ & $\begin{array}{l}0.30^{* *} \\
(0.11)\end{array}$ & $\begin{array}{c}0.11 \\
(0.11)\end{array}$ & $\begin{array}{l}0.42^{*} \\
(0.19)\end{array}$ & $\begin{array}{c}0.20 \\
(0.19)\end{array}$ & $\begin{array}{c}0.18 \\
(0.19)\end{array}$ & $\begin{array}{c}0.09 \\
(0.19)\end{array}$ & $\begin{array}{c}0.00 \\
(0.19)\end{array}$ \\
\hline Many, risk, NGO & $\begin{array}{c}-0.09 \\
(0.11)\end{array}$ & $\begin{array}{c}0.15 \\
(0.11)\end{array}$ & $\begin{array}{c}0.08 \\
(0.11)\end{array}$ & $\begin{array}{c}0.15 \\
(0.11)\end{array}$ & $\begin{array}{l}0.23^{*} \\
(0.11)\end{array}$ & $\begin{array}{c}0.05 \\
(0.18)\end{array}$ & $\begin{array}{c}0.01 \\
(0.18)\end{array}$ & $\begin{array}{c}0.03 \\
(0.18)\end{array}$ & $\begin{array}{c}-0.22 \\
(0.18)\end{array}$ & $\begin{array}{l}-0.25 \\
(0.18)\end{array}$ \\
\hline Constant & $\begin{array}{l}3.55^{* * *} \\
(0.74)\end{array}$ & $\begin{array}{l}3.75^{* * *} \\
(0.76)\end{array}$ & $\begin{array}{c}2.86^{* * *} \\
(0.74)\end{array}$ & $\begin{array}{l}4.14^{* * *} \\
(0.75)\end{array}$ & $\begin{array}{l}3.50^{* * *} \\
(0.76)\end{array}$ & $\begin{array}{l}4.93^{* * *} \\
(1.27)\end{array}$ & $\begin{array}{l}5.00^{* * *} \\
(1.20)\end{array}$ & $\begin{array}{l}1.90 \\
(1.26)\end{array}$ & $\begin{array}{c}7.40^{* * *} \\
(1.26)\end{array}$ & $\begin{array}{l}3.04^{*} \\
(1.26)\end{array}$ \\
\hline Controls & Yes & Yes & Yes & Yes & Yes & Yes & Yes & Yes & Yes & Yes \\
\hline $\mathrm{N}$ & 978.00 & 951.00 & 1014.00 & 958.00 & 945.00 & 426.00 & 416.00 & 429.00 & 411.00 & 416.00 \\
\hline r2_a & 0.05 & 0.02 & 0.03 & 0.08 & 0.03 & 0.13 & 0.15 & 0.08 & 0.17 & 0.08 \\
\hline Control_mean & 3.13 & 3.10 & 3.48 & 2.73 & 3.27 & 3.07 & 2.97 & 3.25 & 3.11 & 3.46 \\
\hline Control_sd & 1.04 & 0.93 & 1.09 & 1.10 & 1.03 & 1.24 & 1.05 & 1.17 & 1.24 & 1.16 \\
\hline
\end{tabular}




\section{A.5 Robustness Tests}

The following Appendix Section reports on robustness tests we conducted.

First of all, adjusting for covariates (including control variables) makes sense in our case. We checked for the balance of means in covariates between the placebo and our five treatment groups. Although we did not find a clear pattern of imbalances in the distribution of covariates, as was expected, some variables show significant differences that were caused by the random assignment of respondents to the treatment conditions. We draw on models with control variables for the "pure" sample as main specifications and report those results in the main text. Below we report and compare the results with (included in Section 5 of the main paper) and without control variables in tabular form see Appendix Tables A.12 for the models with control variables and Appendix Table A.13 for the models without control variables. Given the carryover effects observed between the different parts of the survey, we will focus on the comparison of the models reported the left panel (models 1 to 6) of Appendix Tables A.12 and Appendix Table A.13 labelled as 'Pure sample' in both samples. For details on the distinction between 'pure' and 'full' sample, see Appendix Section A.2.2.

Model 1 (in both tables) estimates treatment effects on the dependent variable whether citizens would want more regulation of corporate behaviour abroad. The results do not differ substantively between the estimations with and without control variables. We observe a slightly (0.08 on a 5-point Likert scale) stronger effect (also of higher statistical significance) on the many, risk, $N G O$-vignette in the model with control variables.

Model 2 (in both tables) uses the statement that voluntary measures are sufficient to reduce environmental and social risks abroad as the dependent variable. Coefficients are statistically significantly different from zero for all vignettes except the many-vignette with and without control variables. Coefficients in the control variables model only differ 
Table A.11: Balance tests for placebo group vs. five voluntary measures treatment groups

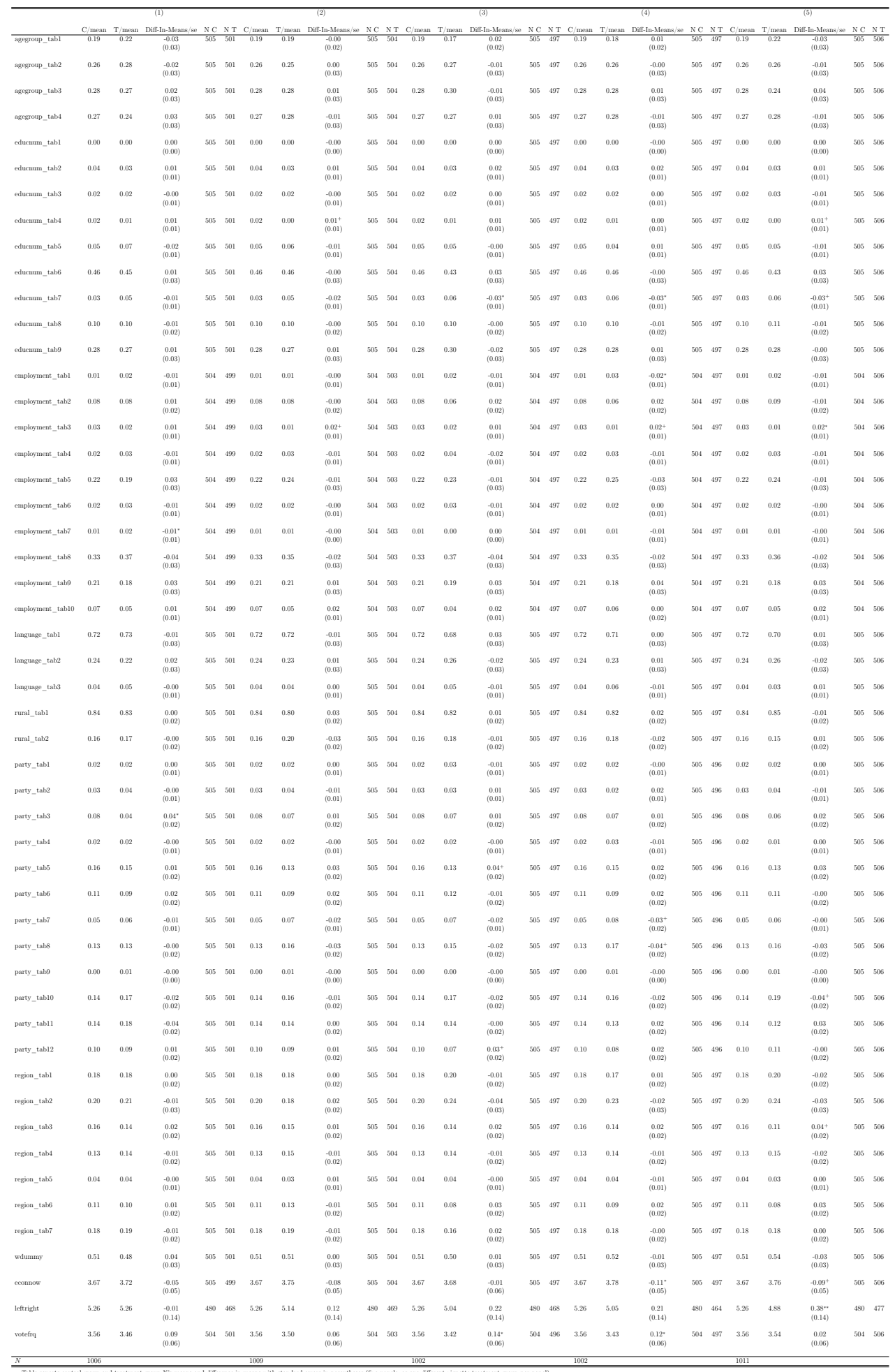


by small amounts ranging from 0.01 to 0.02 on a 5 -point Likert scale from the coefficients in the model without control variables.

Model 3 (in both tables) shows whether respondents rate the RBI differently depending on the treatment conditions (see also: A.16. With and without control variables, the few, risk, NGO and the many, risk, NGO are the only models to induce statistically significant effects in attitudes towards the RBI. We observe a difference between the two models on the many, risk, NGO-vignette and the few, risk, NGO-vignette (0.12 and 0.05 on a 7-point Likert scale respectively).

Models 4 to 6 (in both tables) summarise the effect of our vignettes on whether participants would accept/reject the RBI or whether they do not know yet. Coefficient sizes are almost identical with and without control variables, the differences amounting to 0.03 at most. Statistical significance is increased for some coefficients in the model with control variables. 
Table A.12: How voluntary firm behaviour affects public opinion

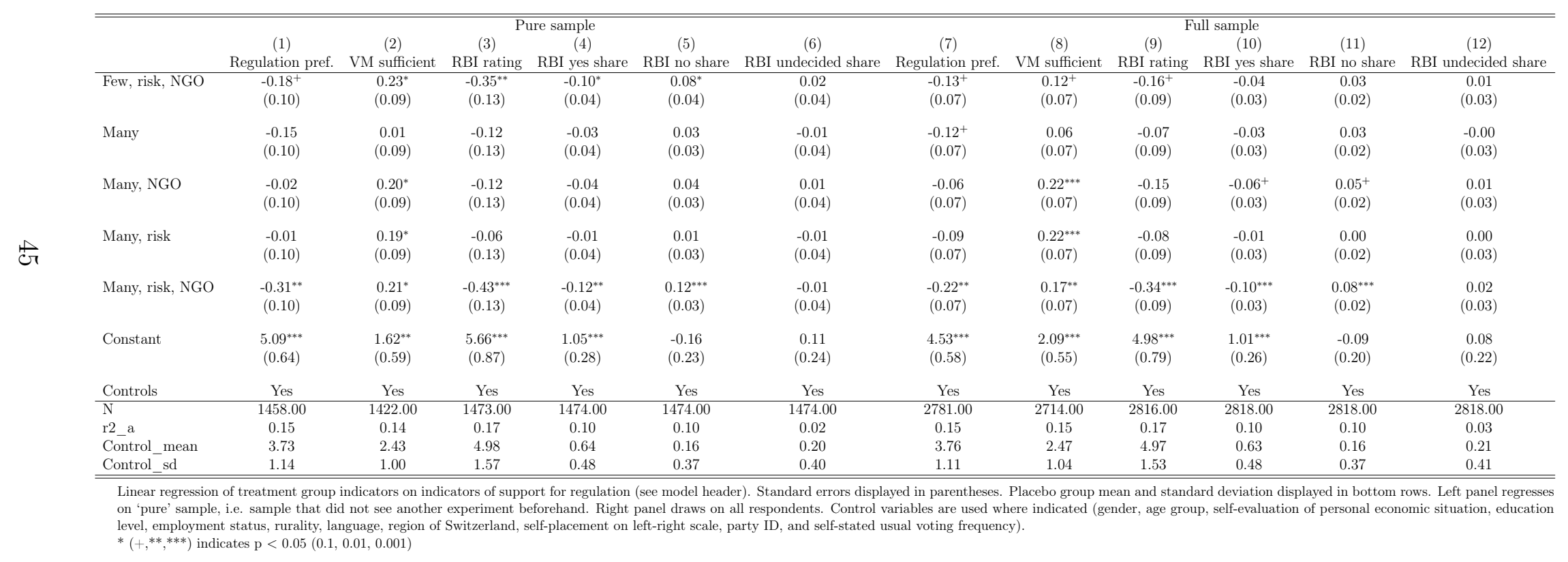


Table A.13: How voluntary firm behaviour affects public opinion - results without control variables

\begin{tabular}{|c|c|c|c|c|c|c|c|c|c|c|c|c|}
\hline & $\begin{array}{c}(1) \\
\text { Regulation pref. }\end{array}$ & $\begin{array}{c}(2) \\
\text { VM sufficient }\end{array}$ & $\begin{array}{r}{ }^{(3)}{ }^{\mathrm{P}} \\
\text { RBI rating } \\
\end{array}$ & $\begin{array}{c}\text { ure sample } \\
\text { (4) } \\
\text { RBI yes share }\end{array}$ & $\begin{array}{l}(5) \\
\text { RBI no share }\end{array}$ & $\begin{array}{c}(6) \\
\text { RBI undecided share }\end{array}$ & $\begin{array}{l}(7) \\
\text { Regulation pref. }\end{array}$ & $\begin{array}{c}(8) \\
\text { VM sufficient }\end{array}$ & $\begin{array}{l}{ }^{(9)}{ }^{\mathrm{F}} \\
\text { RBI rating }\end{array}$ & $\begin{array}{c}\begin{array}{c}\text { Full sample } \\
(10) \\
\text { RBI yes share }\end{array} \\
\end{array}$ & $\begin{array}{c}\text { (11) } \\
\text { RBI no share }\end{array}$ & $\begin{array}{c}(12) \\
\text { RBI undecided share }\end{array}$ \\
\hline Few, risk, NGO & $\begin{array}{l}-0.15 \\
(0.10)\end{array}$ & $\begin{array}{l}0.25^{* *} \\
(0.10)\end{array}$ & $\begin{array}{l}-0.30^{*} \\
(0.14)\end{array}$ & $\begin{array}{l}-0.11^{*} \\
(0.04)\end{array}$ & $\begin{array}{l}0.06^{+} \\
(0.03)\end{array}$ & $\begin{array}{c}0.05 \\
(0.04)\end{array}$ & \begin{tabular}{|l|l|}
$-0.15^{*}$ \\
$(0.07)$
\end{tabular} & $\begin{array}{l}0.13^{+} \\
(0.07)\end{array}$ & $\begin{array}{l}-0.16 \\
(0.10)\end{array}$ & $\begin{array}{l}-0.04 \\
(0.03)\end{array}$ & $\begin{array}{c}0.03 \\
(0.02)\end{array}$ & $\begin{array}{c}0.02 \\
(0.03)\end{array}$ \\
\hline Many & $\begin{array}{l}-0.15 \\
(0.10)\end{array}$ & $\begin{array}{c}0.07 \\
(0.09)\end{array}$ & $\begin{array}{l}-0.15 \\
(0.14)\end{array}$ & $\begin{array}{l}-0.05 \\
(0.04)\end{array}$ & $\begin{array}{c}0.03 \\
(0.03)\end{array}$ & $\begin{array}{l}0.02 \\
(0.04)\end{array}$ & \begin{tabular}{|c}
-0.11 \\
$(0.07)$
\end{tabular} & $\begin{array}{l}0.05 \\
(0.07)\end{array}$ & $\begin{array}{l}-0.04 \\
(0.10)\end{array}$ & $\begin{array}{l}-0.03 \\
(0.03)\end{array}$ & $\begin{array}{c}0.02 \\
(0.02)\end{array}$ & $\begin{array}{l}0.00 \\
(0.03)\end{array}$ \\
\hline Many, NGO & $\begin{array}{l}0.01 \\
(0.10)\end{array}$ & $\begin{array}{l}0.21^{*} \\
(0.09)\end{array}$ & $\begin{array}{l}-0.05 \\
(0.14)\end{array}$ & $\begin{array}{l}-0.05 \\
(0.04)\end{array}$ & $\begin{array}{c}0.03 \\
(0.03)\end{array}$ & $\begin{array}{l}0.02 \\
(0.04)\end{array}$ & $\begin{array}{l}-0.02 \\
(0.07)\end{array}$ & $\begin{array}{l}0.18^{* *} \\
(0.07)\end{array}$ & $\begin{array}{l}-0.05 \\
(0.10)\end{array}$ & $\begin{array}{l}-0.04 \\
(0.03)\end{array}$ & $\begin{array}{c}0.03 \\
(0.02)\end{array}$ & $\begin{array}{l}0.01 \\
(0.03)\end{array}$ \\
\hline Many, risk & $\begin{array}{l}-0.01 \\
(0.10)\end{array}$ & $\begin{array}{l}0.19^{*} \\
(0.10)\end{array}$ & $\begin{array}{l}-0.08 \\
(0.14)\end{array}$ & $\begin{array}{l}-0.02 \\
(0.04)\end{array}$ & $\begin{array}{l}0.00 \\
(0.03)\end{array}$ & $\begin{array}{l}0.02 \\
(0.04)\end{array}$ & \begin{tabular}{|l}
-0.06 \\
$(0.07)$
\end{tabular} & $\begin{array}{l}0.17^{*} \\
(0.07)\end{array}$ & $\begin{array}{l}-0.02 \\
(0.10)\end{array}$ & $\begin{array}{l}0.00 \\
(0.03)\end{array}$ & $\begin{array}{l}-0.01 \\
(0.02)\end{array}$ & $\begin{array}{l}0.01 \\
(0.03)\end{array}$ \\
\hline Many, risk, NGO & $\begin{array}{l}-0.23^{*} \\
(0.10)\end{array}$ & $\begin{array}{l}0.20^{*} \\
(0.09)\end{array}$ & $\begin{array}{l}-0.31^{*} \\
(0.14)\end{array}$ & $\begin{array}{l}-0.10^{*} \\
(0.04)\end{array}$ & $\begin{array}{l}0.09^{* *} \\
(0.03)\end{array}$ & $\begin{array}{l}0.01 \\
(0.04)\end{array}$ & $\begin{array}{c}-0.17^{*} \\
(0.07)\end{array}$ & $\begin{array}{l}0.12^{+} \\
(0.07)\end{array}$ & $\begin{array}{l}-0.22^{*} \\
(0.10)\end{array}$ & $\begin{array}{l}-0.07^{*} \\
(0.03)\end{array}$ & $\begin{array}{l}0.06^{*} \\
(0.02)\end{array}$ & $\begin{array}{l}0.01 \\
(0.03)\end{array}$ \\
\hline Constant & $\begin{array}{l}3.73^{* * *} \\
(0.07)\end{array}$ & $\begin{array}{l}2.43^{* * *} \\
(0.07)\end{array}$ & $\begin{array}{l}4.98^{* * *} \\
(0.10)\end{array}$ & $\begin{array}{l}0.64^{* * *} \\
(0.03)\end{array}$ & $\begin{array}{l}0.16^{* * *} \\
(0.02)\end{array}$ & $\begin{array}{l}0.20^{* * *} \\
(0.03)\end{array}$ & $\begin{array}{l}3.76^{* * *} \\
(0.05)\end{array}$ & $\begin{array}{l}2.47^{* * * *} \\
(0.05)\end{array}$ & $\begin{array}{l}4.97^{* * *} \\
(0.07)\end{array}$ & $\begin{array}{l}0.63^{* * *} \\
(0.02)\end{array}$ & $\begin{array}{l}0.16^{* * *} \\
(0.02)\end{array}$ & $\begin{array}{c}0.21^{1 * * *} \\
(0.02)\end{array}$ \\
\hline $\mathrm{N}$ & 1541.00 & 1499.00 & 1562.00 & 1564.00 & 1564.00 & 1564.00 & 2959.00 & 2881.00 & 3004.00 & 3007.00 & 3007.00 & 3007.00 \\
\hline $\begin{array}{l}\mathrm{r} 2 \text { _a } \\
\text { Control_mean }\end{array}$ & $\begin{array}{l}0.000 \\
3.73\end{array}$ & $\begin{array}{l}0.00 \\
2.43\end{array}$ & $\begin{array}{l}0.000 \\
4.98\end{array}$ & $\begin{array}{l}0.000 \\
0.64\end{array}$ & $\begin{array}{l}0.00 \\
0.16\end{array}$ & $\begin{array}{c}-0.00 \\
0.20\end{array}$ & $\mid \begin{array}{l}0.00 \\
3.76\end{array}$ & $\begin{array}{l}0.00 \\
2.47\end{array}$ & $\begin{array}{l}0.000 \\
4.97\end{array}$ & $\begin{array}{l}0.00 \\
0.63\end{array}$ & $\begin{array}{l}0.00 \\
0.16\end{array}$ & $\begin{array}{r}-0.00 \\
0.21\end{array}$ \\
\hline Control_sd & 1.14 & 1.00 & 1.57 & 0.48 & 0.37 & 0.40 & 1.11 & 1.04 & 1.53 & 0.48 & 0.37 & 0.41 \\
\hline
\end{tabular}


Second, as we use several outcome measures for the same underlying concept of demand for regulation, we follow Mutz (2011) and assess whether our results are affected by measurement error. We derive a more robust measurement of our dependent variable, a combined score from a PCA dimension reduction on our two crowding-out measures, the RBI rating and RBI yes and no voting indicator, standardized with zero mean and a variance of one. While this measure cannot be interpreted directly, it should be less prone to measurement error compared to a single Likert scale item. As reported in Appendix Figure A.15, our results are very similar when using this approach.

Third, since we conduct a test of multiple hypotheses on the same sample of data, we tested our results for robustness with regard to multiple comparisons. To that end, we adjusted the p-values of the coefficients reported in the main paper and the left panel (models 1 to 6 ) of Appendix Table A.12 using the procedure suggested by Benjamini \& Hochberg (1995). This procedure corrects (increases) the p-values based on the false discovery rate - the expected share of 'false rejections of the null hypothesis' among all rejections. The output of this robustness test for our treatment conditions is summarised by Appendix Tables A.14 to A.19 and discussed in greater detail below. In the discussion, we focus on those vignettes, whose coefficients' p-values reached conventional levels (i.e. $\mathrm{p}<10 \%$ ) of statistical significance in the regressions reported in Appendix Table A.12.

Appendix Table A.14 reports raw and adjusted p-values for our treatment conditions in model 1. Model 1 uses participants' support for government regulation of corporate behaviour abroad as the dependent variable. Given the adjusted p-values, we see that even though p-values increase considerably, the many, risk, NGO-vignette retains statistical significance at the $5 \%$ level.

Appendix Table A.15 summarises raw and adjusted p-values for model 2. The dependent variable here is the perception that voluntary measures suffice to address envi- 


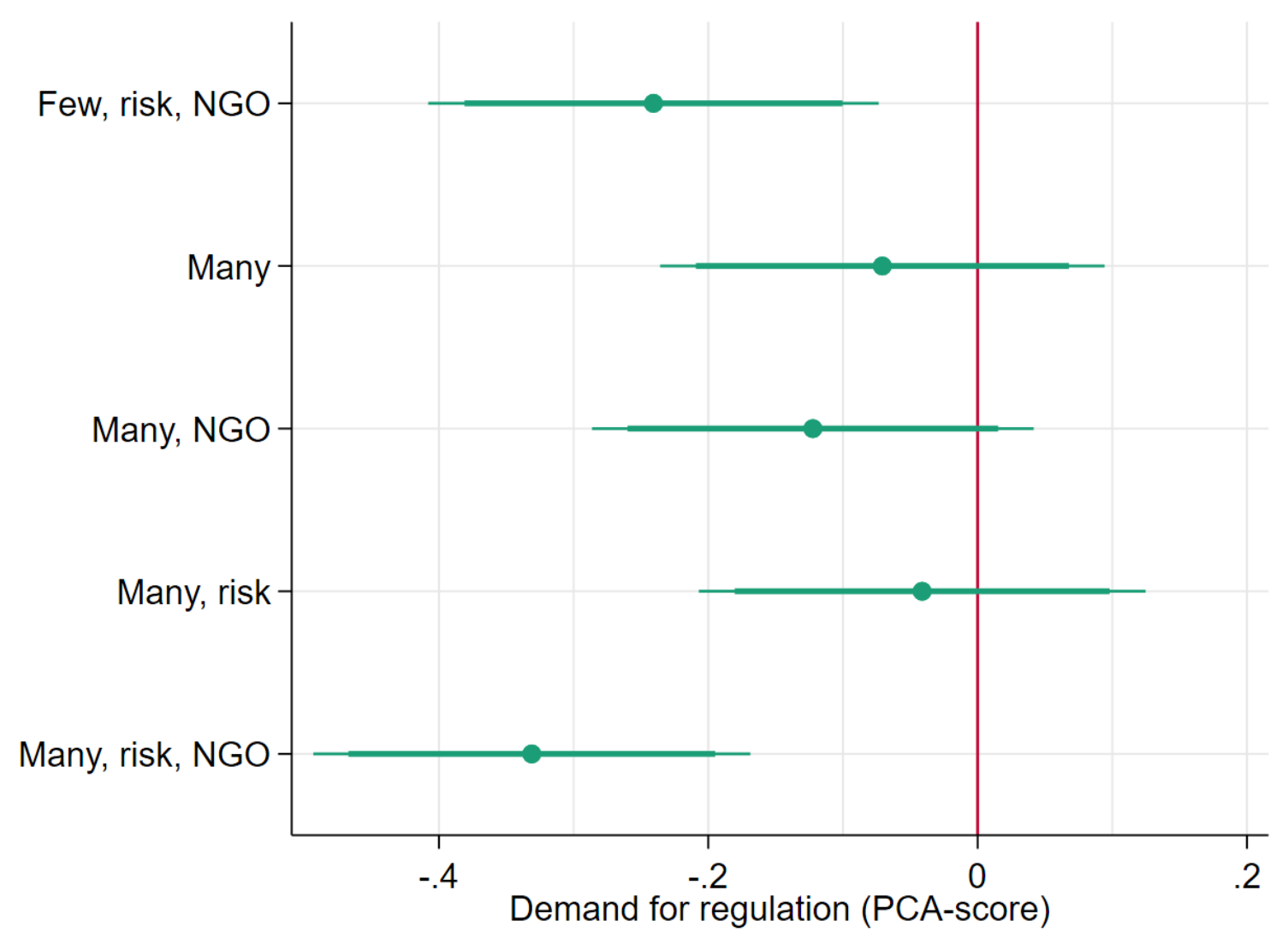

Figure A.15: Treatment effect estimates of vignette conditions relative to the placebo group on outcome variable 'Demand for regulation', derived as first principle component (eigenvalue of 3.11, explaining $62 \%$ of variance) from the two crowding-out measures, the RBI rating and RBI yes and no voting indicator. The regression includes socio-demographic and political controls. Whiskers report $95 \%$ and $90 \%$ confidence intervals.

ronmental and social externalities caused by Swiss MNEs abroad. We observe, that the p-value for the many, risk-vignette increases beyond conventional levels of statistical significance. The adjusted p-values for the few, risk, NGO, the many, $N G O$ and the many, risk, NGO treatment conditions stay in between $5 \%$ and $10 \%$.

Appendix Table A.16 compares raw and adjusted p-values for model 3, whose dependent variable is participants' rating of the RBI. The adjusted p-value for the few, risk, NGO-vignette climbs from $2 \%$ to $10 \%$. However, the High, risk, NGO treatment 
condition retains its $5 \%$ significance level.

Finally, Appendix Tables A.17 to A.19 show the raw and adjusted p-values for models 4 to 6 , estimating the effect of our treatment conditions on the RBI yes and no shares as well as the on the 'undecided' share. The effect induced by the few, risk, NGO-vignette is on the margin of the $10 \%$ level in model 4 (yes share) and loses statistical significance in model 5 (no share). In contrast, the coefficient estimated for the many, risk, NGOvignette remains statistically significant at the $10 \%$ level in model 4 (yes share) and at the $5 \%$ level in model 5 (no share). We did not observe statistically significant effects of our treatments on the undecided share.

In sum then, if we adjust the p-values of our treatment effect estimates such as to provide a more conservative measurement of statistical significance, our main findings remain robust. For voluntary corporate initiatives to reduce support for government regulation of corporate behaviour abroad, and to reduce support for the RBI, in particular, participation by a large share of companies, participation of companies in high-risk sectors and external oversight are required. Moreover, given the adjusted p-values, the effects triggered by the vignette combining engagement by a small share of the private sector, high-risk sector companies and external oversight should be interpreted with caution.

Table A.14: P-values of treatments effects on support for more government regulation

\begin{tabular}{rrr}
\hline & $\mathrm{p}$ & $\mathrm{bh}$ \\
\hline Few, risk, NGO & 0.12 & 0.30 \\
Many & 0.13 & 0.31 \\
Many, NGO & 0.80 & 0.90 \\
Many, risk & 0.94 & 0.98 \\
Many, risk, NGO & 0.00 & 0.03 \\
\hline
\end{tabular}

Left column: p-values based on regression reported in model 1 in Appendix Table A.12. Right column: p-values from left column adjusted by the procedure of Benjamini and Hochberg. 
Table A.15: P-values of treatments effects on perception that voluntary measures suffice

\begin{tabular}{rrr}
\hline & $\mathrm{p}$ & $\mathrm{bh}$ \\
\hline Few, risk, NGO & 0.01 & 0.06 \\
Many & 0.64 & 0.80 \\
Many, NGO & 0.01 & 0.08 \\
Many, risk & 0.03 & 0.17 \\
Many, risk, NGO & 0.01 & 0.07
\end{tabular}

Left column: p-values based on regression reported in model 2 in Appendix Table A.12.

Right column: p-values from left column adjusted by the procedure of Benjamini and Hochberg.

Table A.16: P-values of treatments effects on rating of the RBI

\begin{tabular}{rrr}
\hline & $\mathrm{p}$ & $\mathrm{bh}$ \\
\hline Few, risk, NGO & 0.02 & 0.10 \\
Many & 0.31 & 0.65 \\
Many, NGO & 0.46 & 0.79 \\
Many, risk & 0.44 & 0.77 \\
Many, risk, NGO & 0.00 & 0.02 \\
\hline
\end{tabular}

Left column: p-values based on regression reported in model 3 in Appendix Table A.12.

Right column: p-values from left column adjusted by the procedure of Benjamini and Hochberg.

Table A.17: P-values of treatments effects on RBI yes share

\begin{tabular}{rrr}
\hline & $\mathrm{p}$ & $\mathrm{bh}$ \\
\hline Few, risk, NGO & 0.02 & 0.10 \\
Many & 0.39 & 0.58 \\
Many, NGO & 0.26 & 0.47 \\
Many, risk & 0.63 & 0.73 \\
Many, risk, NGO & 0.01 & 0.06 \\
\hline
\end{tabular}

Left column: p-values based on regression reported in model 4 in Appendix Table A.12.

Right column: p-values from left column adjusted by the procedure of Benjamini and Hochberg.

Table A.18: P-values of treatments effects on RBI no share

\begin{tabular}{rrr}
\hline & $\mathrm{p}$ & $\mathrm{bh}$ \\
\hline Few, risk, NGO & 0.07 & 0.36 \\
Many & 0.44 & 0.66 \\
Many, NGO & 0.30 & 0.53 \\
Many, risk & 0.88 & 0.97 \\
Many, risk, NGO & 0.00 & 0.03 \\
\hline
\end{tabular}

Left column: p-values based on regression reported in model 5 in Appendix Table A.12.

Right column: p-values from left column adjusted by the procedure of Benjamini and Hochberg. 
Table A.19: P-values of treatments effects on RBI undecided share

\begin{tabular}{rrr}
\hline & $\mathrm{p}$ & $\mathrm{bh}$ \\
\hline Few, risk, NGO & 0.26 & 0.71 \\
Many & 0.78 & 0.98 \\
Many, NGO & 0.73 & 0.98 \\
Many, risk & 0.68 & 0.98 \\
Many, risk, NGO & 0.94 & 0.98 \\
\hline
\end{tabular}

Left column: p-values based on regression reported in model 6 in Appendix Table A.12.

Right column: p-values from left column adjusted by the procedure of Benjamini and Hochberg.

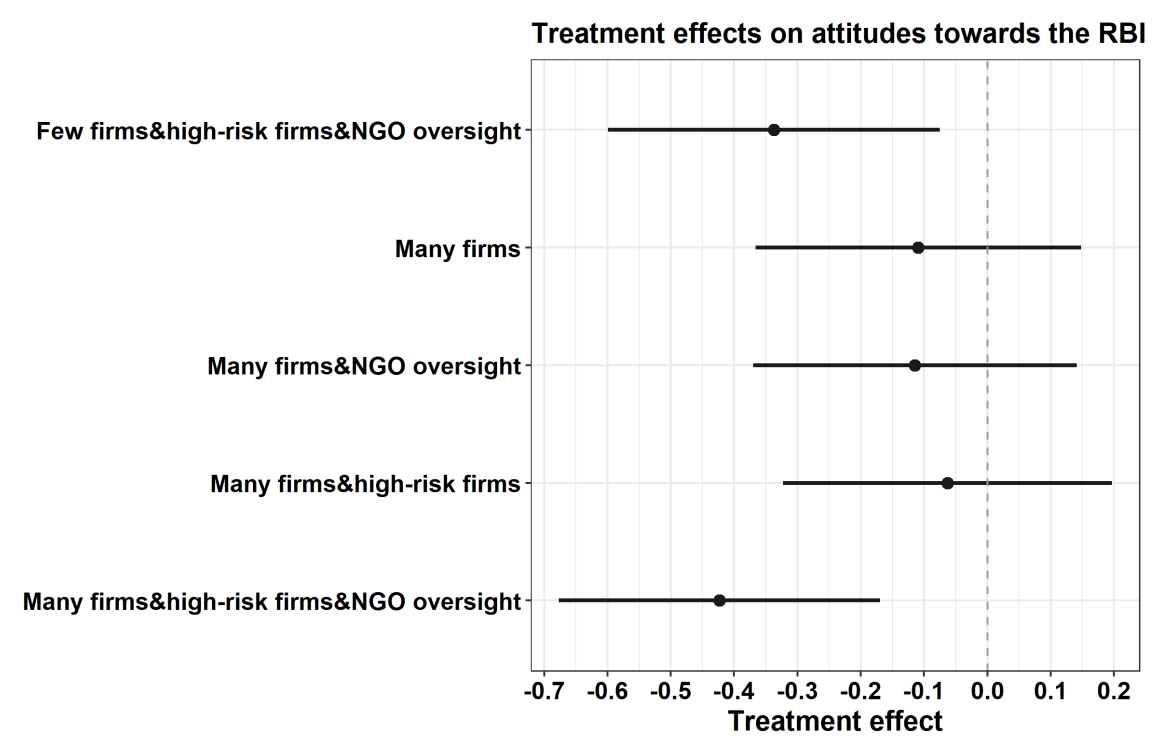

Figure A.16: Estimates of treatment effects of vignette conditions relative to the placebo group on the outcome variable 'RBI attitudes' (item wording: "On a scale from 1 (totally opposed) to seven (totally in favour), how strongly are you for or against the Responsible Business Initiative" $(\mathrm{N}=1471)$. Whiskers report $95 \%$ confidence intervals. The regression includes socio-demographic and political control variables. Full results are reported in Appendix Table A.12 